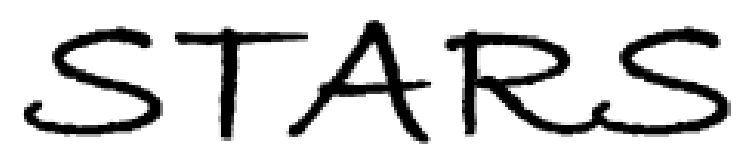

University of Central Florida

STARS

2013

\title{
The Inclusion Of Women's History In The Secondary Social Studies Classroom
}

Cicely Scheiner-Fisher

University of Central Florida

Part of the Education Commons

Find similar works at: https://stars.library.ucf.edu/etd

University of Central Florida Libraries http://library.ucf.edu

This Doctoral Dissertation (Open Access) is brought to you for free and open access by STARS. It has been accepted for inclusion in Electronic Theses and Dissertations, 2004-2019 by an authorized administrator of STARS. For more information, please contact STARS@ucf.edu.

\section{STARS Citation}

Scheiner-Fisher, Cicely, "The Inclusion Of Women's History In The Secondary Social Studies Classroom" (2013). Electronic Theses and Dissertations, 2004-2019. 2848.

https://stars.library.ucf.edu/etd/2848

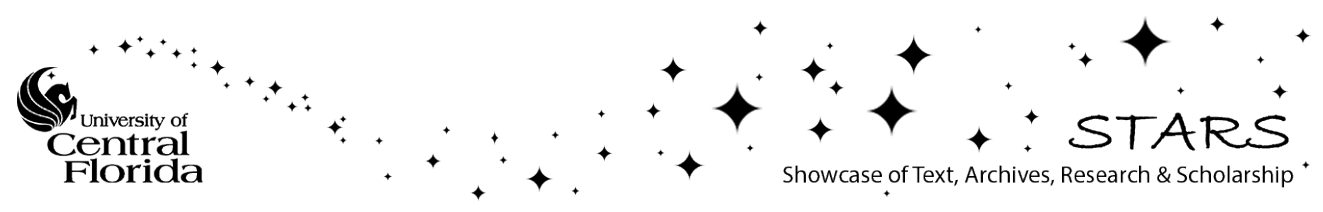




\section{THE INCLUSION OF WOMEN'S HISTORY IN THE SECONDARY SOCIAL STUDIES CLASSROOM}

by

\section{CICELY SCHEINER-FISHER}

B.S. University of South Florida 2001

M. Ed. University of Central Florida 2010

A dissertation submitted in partial fulfillment of the requirements

for the degree of Doctor of Philosophy

in the College of Education

at the University of Central Florida

Orlando, Florida

Summer Term

2013

Major Professor: William B. Russell 


\begin{abstract}
The author examined the motivation for why, and methods of how, some secondary social studies teachers incorporate women's voices into the traditional history framework. A multi-layered qualitative methodology was employed for this study using survey, case study, and phenomenological approaches, including interviews and classroom observations of participants. The researcher discovered the percentage of teachers who claim to incorporate women's history/perspectives into their lessons; how teachers incorporate women's history/perspectives into their lessons; and, the factors that contribute to teachers including women's history/perspectives into their classes.
\end{abstract}


Dedicated to current and future feminist educators. 


\section{ACKNOWLEDGMENTS \\ "The miracle isn't that I finished, it's that I had the courage to start." -John Bingham}

I am overflowing with gratitude for all of the people who have supported me along this journey. This has been one of the greatest and most rewarding challenges in my life, and I could not have accomplished it without the support of so many.

- First, I would like to thank my husband James Fisher for his unwavering encouragement throughout this process. He has served as a guide and an inspiration, and has picked up the slack at home when necessary. And promised me my very own camel if I finished on time.

- Thank you to Dr. William Russell, who served as chair for my committee, answering questions, and guiding me along the way. Dr. Russell not only broadened my horizons within the social studies, he also mentored me as a writer and scholar, and without all of his efforts, I would not be where I am today.

- My committee members, Dr. Terri S. Fine, Dr. Randy Hewitt, and Dr. Richard Hartshorne, thank you so much for sticking with me throughout this process, for providing mentorship, and allowing me to work along side you on a number of projects. Dr. Fine, especially, you have been an inspiration to me, and provided more support than you can imagine. 
- Dr. Scott Waring, thank you for bringing me into this program, providing me the opportunity to work with the Library of Congress, and believing in me throughout my studies. You provided guidance and support, and for that I am grateful.

- Thank you to my friends and colleagues in this program, who have been the most helpful influences one could hope for-Barbara Houser and Christopher Busey, thank YOU!

- And finally, my wonderful family — my parents: Margie and Allen for their love, guidance, encouragement, and emotional and financial support through the years. My sister Carly, who although she still has no idea what my dissertation is on, gave me love and inspiration throughout my whole life. And my in-laws, Janice and Seth, who provided me the best support in the world, my partner. 


\section{TABLE OF CONTENTS}

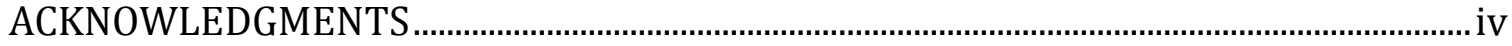

LIST OF FIGURES .................................................................................................................................... viii

LIST OF TABLES .........................................................................................................................................ix

CHAPTER 1: INTRODUCTION...........................................................................................

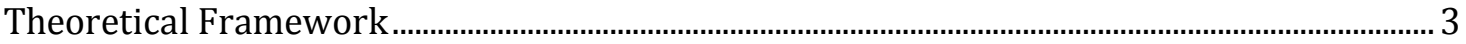

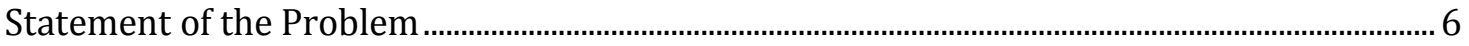

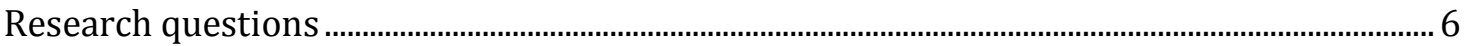

Definition of Terms ................................................................................................................................................

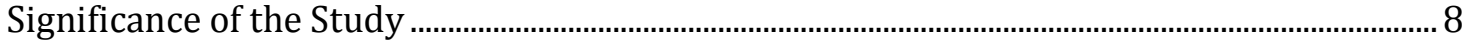

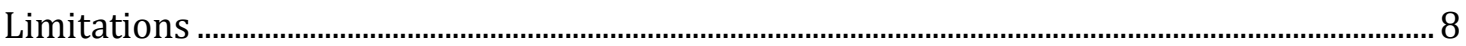

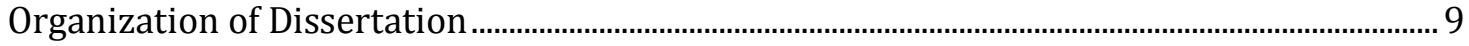

CHAPTER 2: LITERATURE REVIEW ................................................................................... 10

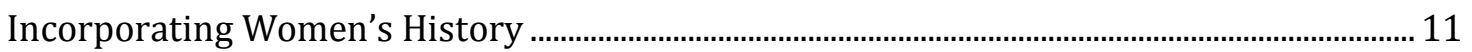

Social Studies Curriculum......................................................................................................................... 18

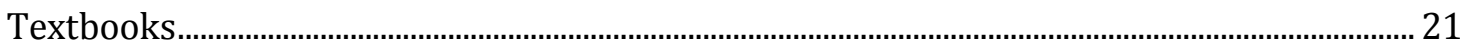

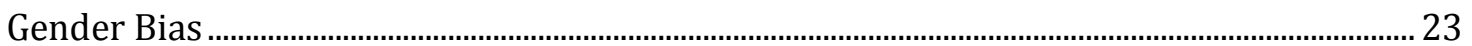

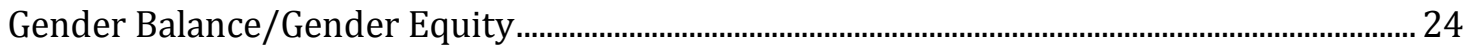

Recommendations for Incorporating Women's Voices ............................................................... 26

CHAPTER 3: METHODOLOGY........................................................................................ 29

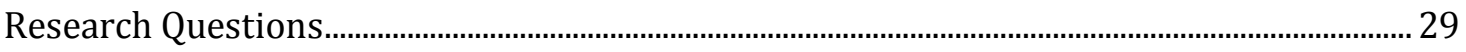

Feminist Research Strategies ............................................................................................................... 29

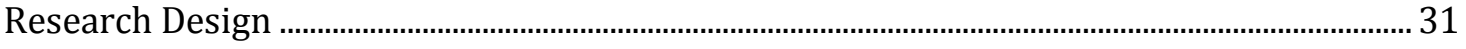

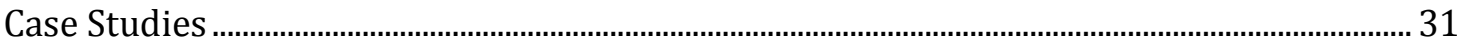

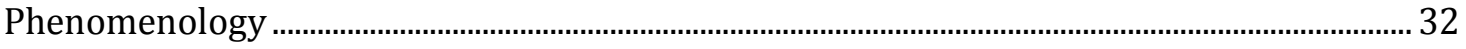

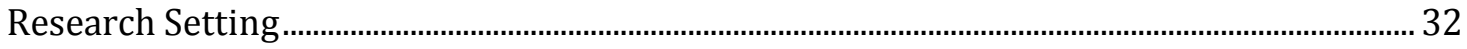

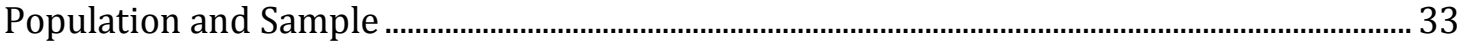

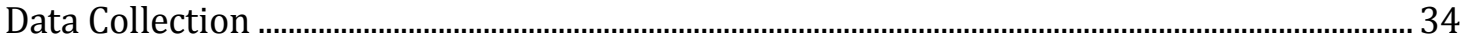

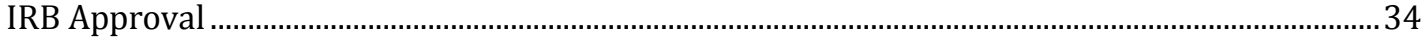

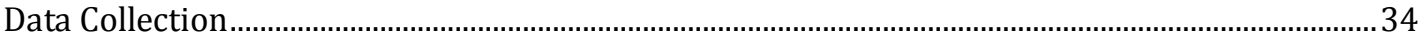

Interviews................................................................................................................................

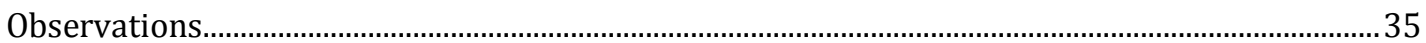

Data Analysis ...................................................................................................................................

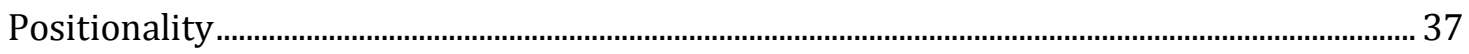

CHAPTER 4: FINDINGS AND DISCUSSION ........................................................................... 40 


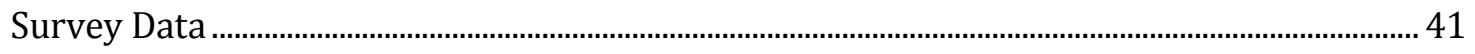

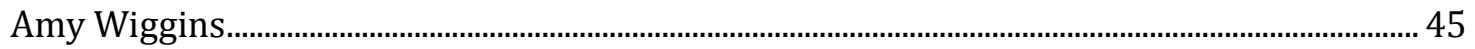

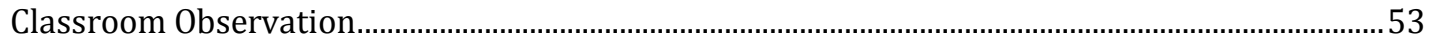

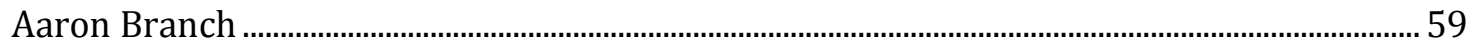

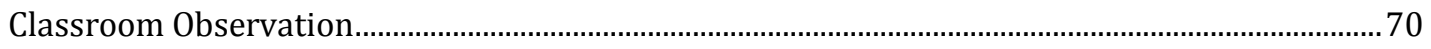

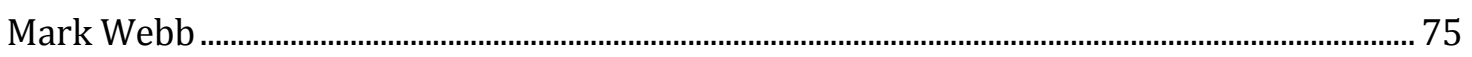

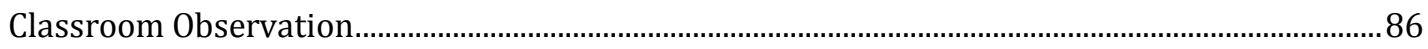

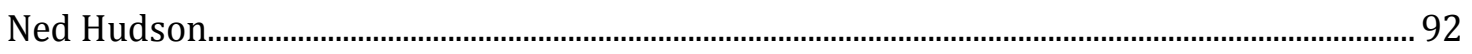

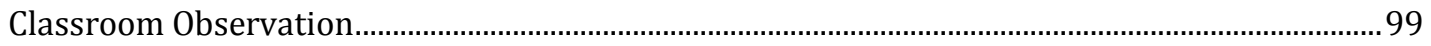

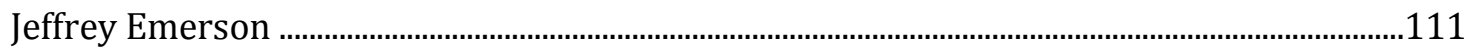

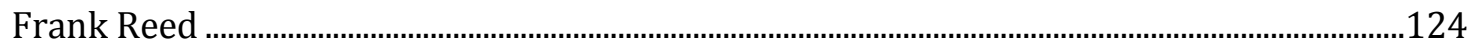

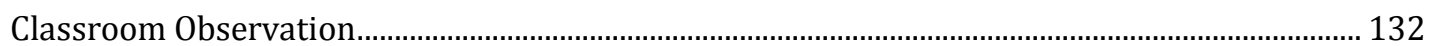

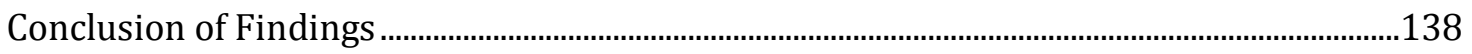

CHAPTER 5: CONCLUSIONS AND IMPLICATIONS................................................................139

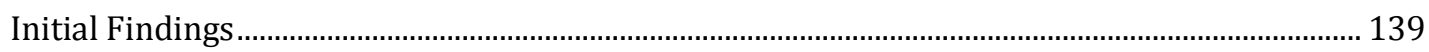

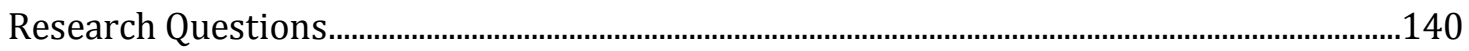

Question 1: Are teachers incorporating gender and women's history in their lessons?............. 140

Question 2: How do teachers incorporate women's history/perspectives into the lesson?...... 141 Question 3: What factors contribute to teachers including women's history/perspectives in

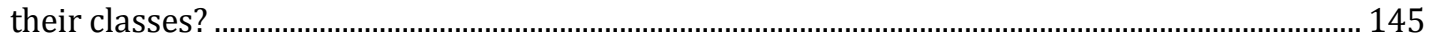

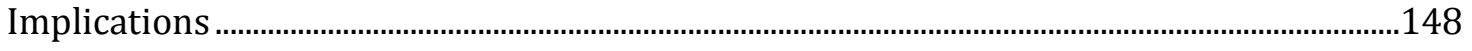

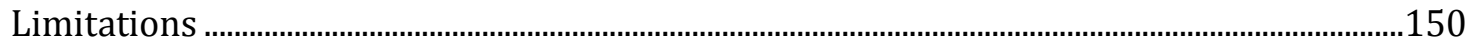

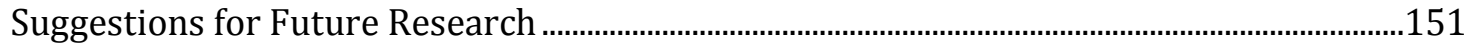

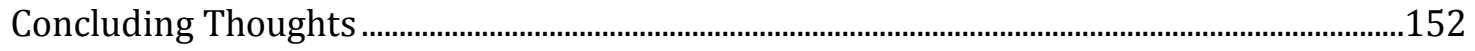

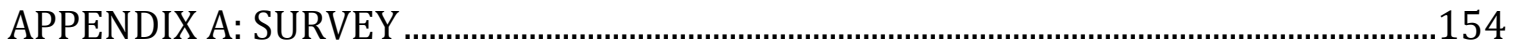

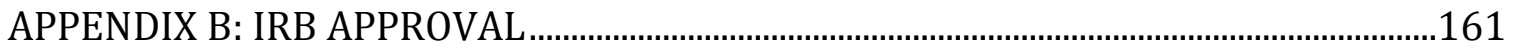

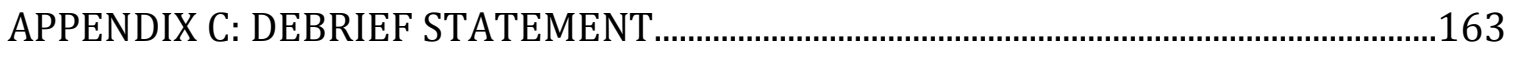

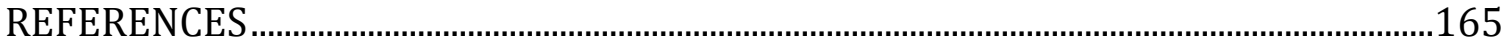




\section{LIST OF FIGURES}

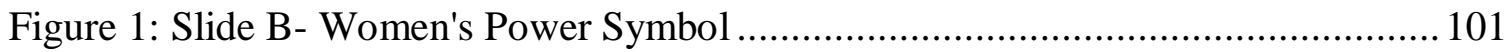

Figure 2: Slide C- The Divorce Rate Over Time ..................................................... 103

Figure 3: Slide D- The Rise in Divorce Rates ........................................................ 104

Figure 4: Slide E- Death of Marriage in the US ..................................................... 106

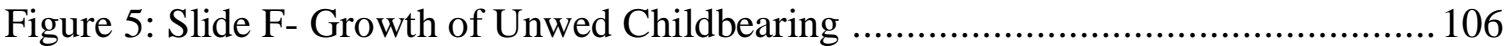

Figure 6: Slide G- Earnings in Relation to Men's Earnings ........................................ 107

Figure 7: Slide H- Women's Earnings as a Percentage of Men's 2012 ......................... 108

Figure 8: Slide I- Annual Median Income Level by Race and Gender 2009 ................. 109

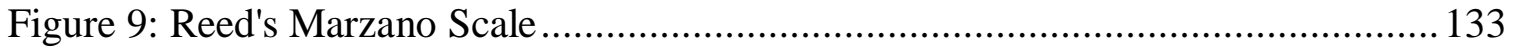

Figure 10: Directions for Group Work in Mr. Reed's Class ..................................... 136

Figure 11: Research Question/Data Form ...................................................... 140

Figure 12: Participant's Stages of Including Women's History (Lesson Based)............. 142 


\section{LIST OF TABLES}

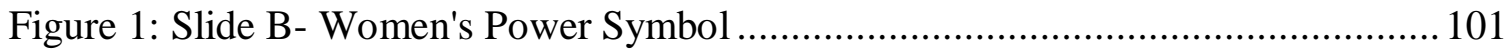

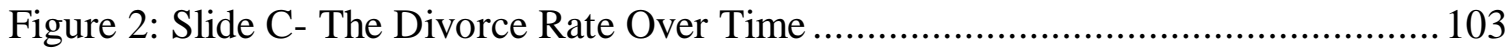

Figure 3: Slide D- The Rise in Divorce Rates ...................................................... 104

Figure 4: Slide E- Death of Marriage in the US ............................................... 106

Figure 5: Slide F- Growth of Unwed Childbearing ............................................... 106

Figure 6: Slide G- Earnings in Relation to Men's Earnings ....................................... 107

Figure 7: Slide H- Women's Earnings as a Percentage of Men's 2012 ......................... 108

Figure 8: Slide I- Annual Median Income Level by Race and Gender 2009 ................. 109

Figure 9: Reed's Marzano Scale .............................................................................. 133

Figure 10: Directions for Group Work in Mr. Reed's Class ..................................... 136

Figure 11: Research Question/Data Form ........................................................ 140

Figure 12: Participant's Stages of Including Women's History (Lesson Based)............. 142 


\section{CHAPTER 1: INTRODUCTION}

Incorporating women's history in to traditional history classes has been the subject of a number of articles and studies. "Scholars, curriculum developers, and learned societies have called for a more gender-balanced curriculum" (Cruz \& Groendal-Cobb, 1998). Yet, during a conversation with a practicing World Human Geography teacher, while I was looking for possible participants for my study, I asked if he taught using multiple perspectives. He replied that he did, to which I asked about his incorporation of women's voices. This teacher, who is in the process of attaining his master's degree in social science education, replied that he did not incorporate women's voices or perspectives because it was too hard; but he did say that the girls in the class always ask him "what about the women?"

Women's history as a field of research began to gain notoriety in the 1970's when "sharp changes in the politics of the women's movement drew women's history into the consciousness of the historical community" (Kessler-Harris, 2007). During this time, scholars such as Gerda Lerner devised methods for examining the portrayal and inclusion of women in textbooks and curriculum (Lerner, 1981). In her article on the portrayal of women in high school history textbooks, Trecker (1973) noted that in the 1930's Arthur Schlesinger questioned whether women have ever made any contributions to American national progress that were worthy of

record. She made the observation of the unfortunate nature of the inquiry,

Instead of trying to find out what women have contributed to America, most historians and students have been content to answer Professor Schlesinger by saying, 'But women haven't done anything,' the fact of the matter is not that 
women haven't made important contributions, but that their history has not been recorded (Trecker, 1973).

Since the 1970's little inroads have been made in this area. Noddings (1992) noted that women's contributions are not clearly apparent due to the fact that the social studies curriculum is inherently masculine in that its focus tends to rest in military, political, and economic history; thus the areas in which women have been active: private sector, peace studies, and social history, are continually marginalized. For the past several decades there has been a prodigious increase in the scholarly work surrounding the history of women. There has also been call after call from academics for educators to incorporate women's history into their traditional social studies classes. These calls have made recommendations ranging from tying in primary sources, to utilizing feminist teaching methods, to shifting the emphasis from political/military/economic history to social history in which women's contributions have been recorded (Berkin, Crocco, \& Winslow, 2009; Copp \& Kleinman, 2008; Crocco, 1997; Cruz \& Groendal-Cobb, 1998; Tetreault, 1986a; Woyshner, 2011).

Unfortunately, even though there have been great advances in the amount of information and history available through academics and national organizations, women's history has not trickled down to the K-12 level. Curriculum specialists in a number of states have stated that "they thought that content on women was infused into courses such as U.S. history. That assumption, however, is not supported if social studies curriculum standards and textbooks are any indication of the curricular content that is delivered to students" (Hahn, Bernard-Powers, Crocco, \& Woyshner, 2007). Woyshner (2011) stated, "The biggest mistake we can make is to assume the notion of progress, that each year the curriculum becomes more sophisticated, more inclusive, and more reflective of self and society" (p. 261). The fact is, that although the 1980's 
and 1990's established a place for gender and women's history, there was indeed a backlash before and after years of No Child Left Behind (NCLB, 2001). This act deemphasized social studies through a lack of federal funding for gender-related research and placed the assumption that gender equity has been realized which, as research shows, is far from accurate. Gender studies and women's history have once again been excluded from the social studies curriculum (Hahn et al., 2007). There is a cultural assumption that gender equity has been realized, Many still ask, 'What is feminism?' 'Haven't things changed, aren't women in high-powered positions across society (government, business, media/Hollywood), aren't things equal, since women can do just about whatever they want now?' The perception of equality or achievement is not the overwhelming reality. The exception is never the rule, and many young women and men are left shortchanged both by an educational system that ill prepares them for a critical literacy of agency and by a society that conflates money with accomplishment (Villaverde, 2008, p. 2).

As Villaverde explains, although women have made inroads into high-powered positions, equality has not been fully achieved, as those instances in which women have achieved greatness are not the norm.

\section{Theoretical Framework}

This study has been framed by several interpretive positions: feminist theory, social constructivist approaches, and critical theory. Most influential is feminist theory in which feminist researchers see gender as a basic organizing principle that shapes the condition of women's lives. The aim of the ideological research is to "correct both the invisibility and 
distortion of female experience in ways relevant to ending women's unequal social position" (Lather, 1991, p. 71).

Beyond feminist theory, the research will also take a social constructivist approach due to the fact that the research reflects the participants' views. Furthermore, social constructivist work holds to the conviction that something is not right about the status quo; nothing is inevitable; and systems are not put into place because of human nature, rather, they are socially constructed (Kivinen \& Ristela, 2003, p. 364). These precepts are common also to the pragmatic view of education. The underlying characteristic common to both philosophies, meliorism, the view that human action can improve the human condition, guides the research as the goal of all feminist studies is to, as is stated above, end women's unequal social position (Seigfried, 1996, p. 8).

Philosophies such as pragmatism and constructivism rely heavily on language as a guiding principle; "when we describe the world we do so within the confines of a certain language game, or vocabulary" (Kivinen \& Ristela, 2003, p. 367). However, poststructuralists see discourses "not as a group of words or sets of signifiers which simply refer to or describe reality. Instead, discourses are described as 'practices that systematically form the objects of which they speak"' (Schmeichel, 2011). The importance of analyzing language and discourse in this study is, as Schmeichel points out, that the possibilities of what we think and what we know is "made possible only through the discourses to which we have access" (p.13). Students and teachers who do not have access to, or have never been exposed to gender and women's history, or feminist philosophies about teaching, simply do not have the discourse or knowledge base from which to work. Thus, participants' can only teach what they know, they can only speak about experiences that they have had, and their realities have shaped their teaching practices. 
Another lens has been utilized to create this theoretical framework: critical theory, which aims to empower human beings to transcend the constraints placed on them by race, class and gender. Critical theory, according to Creswell is

A theoretical lens used in qualitative research in which a researcher examines the study of social institutions and their transformations through interpreting the meanings of social life; the historical problems of domination, alienation, and social struggles; and a critique of society and the envisioning of new possibilities (p. 247).

In addition to the above interpretive positions, several constructs surrounding the inclusion of women's history/perspectives in the secondary social studies classroom will be examined: educational goals, integrating women's history, rationale for incorporating women's history, gender bias, and gender balance.

Finally, I will use Tetreault's "Stages of Thinking About Women in History" as the guideline for the inclusion of women's history in the traditional social studies classroom. This framework contains five phases: Male History (in which the absence of women is not noted), Compensatory History (the absence of women is noted; there is a search for missing women according the male norm of greatness), Bi-focal History (focus on women's oppression and misogyny; women's efforts to overcome oppression are presented), Feminist History (women's experience is analyzed within the social, cultural, historical, political, and economic contexts), and Multi-focal/Relational History (seeks to fuse women's and men's experiences into a holistic view of the human experience)(Tetreault, 1986a). The assumption being that each participant involved in this study will fall somewhere along the continuum of women's history inclusion. 


\section{Statement of the Problem}

The dominance of the male paradigm in history and the dearth of lessons on women's history in typical secondary social studies classrooms, leave an impression on students that women have never played a valuable role in society. Populations whose histories are left out of the narrative are left with the impression that they are worth less than those whose stories are prevalent in the texts and school curricular culture. One of the most effective ways in which dominant groups maintain their power is by depriving the people they dominate of the knowledge of their own history (Schafer, 2007, p. 27).

When children do not see girls and women in the pages of textbooks and teachers do not point out or confront the omissions, our daughters, and our sons learn that to be female is to be an absent partner in the development of our nation (Sadker, Sadker, \& Zittleman, 2009, p. 18)

Moreover, because the masculine narrative is accepted as the universal experience, oppressive systems are replicated rather than criticized and ameliorated.

Secondary social studies teachers can contribute to this problem by not seeking to include the narratives of women in history. Teachers who consistently focus on military or political history can easily overlook the contributions of women or find themselves mentioning only those contributions of the wives of important men or women who achieved recognition as "the first female" in an arena traditionally populated by men.

\section{Research questions}

This research study employed a multi-layered, qualitative research method (survey, interviews, and field observations) to answer the following questions:

1. Are teachers incorporating women's history/perspectives in their lessons? 
2. How do teachers incorporate women's history/perspectives into their lessons?

3. What factors contribute to teachers including women's history/perspectives in their classes?

\section{Definition of Terms}

Feminism:

any of multiple theories or perspective either based on the premise that women have been and continue to be oppressed, in which case the emancipation and empowerment of women is taken as a goal, or based on the premise that gender is a fundamental category of analysis (Seigfried, 1996).

Gender:

refers to the ways in which human societies have conceptualized and sorted the categories (social identities) and plans (attributes and roles) flowing from the material realities of biological differences (Hahn et al., 2007). Gender "raises questions not so much about what women did or did not do, but how the organization of relationship between men and women established priorities and motivated social and political action" (Kessler-Harris, 2007).

Women's history: is the study of the role that women have played in history; together with the methods needed to study women. It includes the study of the history of the growth (and decline) of woman's rights throughout recorded history, the examination of individual women of historical significance, and the effect that historical events have had on women. Inherent in the study of women's history is the belief that more traditional recordings of history have minimized or ignored the contributions of women and the effect that historical events had on women as a whole; in this respect, woman's history is often a form of historical revisionism, seeking to challenge or expand the traditional historical consensus (Purvis, 2004).

Social Studies

The integrated study of the social sciences and humanities to promote civic competence. Within the school program, social studies provides coordinated, systematic study drawing on such disciplines as anthropology, archaeology, economics, geography, history, law, philosophy, political science, psychology, religion, sociology, as well as appropriate content from the humanities, mathematics, and natural sciences. The primary purpose of social studies is to help young people make informed and reasoned decisions for the 
public good as citizens of a culturally diverse, democratic society in an interdependent world (NCSS, 1994).

\section{Significance of the Study}

Much research has been done on the social studies curriculum, standards and textbooks as related to gender and women's history (Berkin et al., 2009; Crocco, 1997, 2001, 2008; Hahn, 1996; Hahn et al., 2007; Holt, 1990; Klein, Ortman, \& Friedman, 2002; Lerner, 1993; Noddings, 1992; Rogers, 1990; Schafer, 2007; Tetreault, 1986b, 1987; Trecker, 1973; Woyshner, 2011).

Yet, there has not been any extensive attention paid to how gender interacts with the instructional process in the social studies classroom (Hahn et al., 2007, p. 338). This study aims to understand the factors that contribute to teachers including gender issues and women's history in their traditional social studies classroom.

\section{Limitations}

There are several limitations to this study. First, the participants will be selected from a southeastern region, thus the data and conclusions will have a regional, rather than national perspective. Additionally, this study only addresses secondary social studies teachers who incorporate gender and women's history into their curriculum. This concentration unintentionally denies the contributions of elementary teachers who promote gender equity in their classes. Furthermore, this study does not look at the inclusion of sexuality issues nor of the presence of other multiple perspectives such as race, class, or ethnicity. Finally, this study does not address the construction of male identities or theories of masculinity. 


\section{Organization of Dissertation}

The remainder of this dissertation is organized into five chapters, a bibliography, and appendices. The chapters will be organized as follows:

Chapter 2: provides a review of literature relevant to the study. The review includes research on incorporating women's history, the social studies curriculum, textbooks, gender bias, gender balance/gender equity, and recommendations for including women's voices in the social studies classroom.

Chapter 3: opens with a synopsis of the methodology use to plan this study. A description of data collection and data analysis methods is detailed. The researcher's positionality is examined in relation to the theoretical framework.

Chapter 4: presents findings from each of the data collection methods. Survey data is provided with statistical analysis, and each participant interview and observational data are discussed.

Chapter 5: provides conclusions and implications of findings. Discussion of meaning and comparison of participants' interview and observational data is included. 


\section{CHAPTER 2: LITERATURE REVIEW}

"Each time a girl opens a book and reads a womanless history, she learns she is worth less." Myra Pollack Sadler (Failing at Fairness, 1982)

This chapter begins with a review of the theoretical framework on incorporating women's history/perspectives into the social studies curriculum. By reviewing this literature, this chapter develops a groundwork for answering the research questions:

1. How do teachers incorporate gender and women's history/perspectives into their lessons?

2. What factors contribute to teachers including women's history/perspectives issues in their classes?

Boote and Beile (2005) argue the literature review should set the broad context of the study, demarcate what is and what is not within the scope of the investigation, and situate an existing literature in a broader scholarly and historical context. This chapter offers a review of the literature in several areas: educational goals, integrating women's history, rationale for incorporating women's history, gender bias, and gender balance.

The research that follows is guided by the interpretive positions of postmodernism, feminist theory, and critical theory. Through the postmodern lens, the importance of discourse and marginalized groups has been examined. Feminist theory is connected to the postmodern challenge to the societal status quo; however feminist researchers see gender as a basic organizing principle that shapes the condition of their lives. The aim of the ideological research is to "correct both the invisibility and distortion of female experience in ways relevant to ending 
women's unequal social position" (Lather, 1991, p. 71). Critical Theory works to empower human beings to transcend the constraints placed on them by race, class and gender (Creswell, 2007). Therefore, it is through these lenses that the literature has been examined.

\section{Incorporating Women's History}

Margaret Crocco (1999) pointed out that, "Across the social studies as well as in history, women's contributions have been ignored, underestimated, or marginalized" (Crocco, 1999, p. 8). Woyshner (2011) examined the ways that gender is generally addressed in social studies classes by discussing common frameworks used in gender inclusion. She focused on three theoretical frameworks: phase models, care tradition and social education. The phase models, as outlined by Woyshner, helped identify a progression for integrating women's history in the social studies curriculum. She described two, one that she identifies as the Lerner model (1981) and the second, the McIntosh Model (1983).

The Lerner model begins with male-defined history, moves on to "compensatory history" in which missing and notable women are added; then "contribution history" in which women's contributions to male-defined society are highlighted; next, "oppression framework" where women's history is told in terms of oppression, and women are added on their own terms in history, e.g. suffrage (Woyshner, 2011).

The Lerner model provided the basis for Tetreault's phase theory of common stages of thinking about women (Table 1) which uses Lerner's schema as a conceptual framework (Tetreault, 1986a). 
Table 1: Tetreault's "Stages of Thinking about Women in History"

\begin{tabular}{|c|c|}
\hline Male History & $\begin{array}{l}\text { The absence of women is not noted, "There is not consciousness that the male experience is a 'particular knowledge' } \\
\text { selected from a wider universe of possible knowledge and experience." }\end{array}$ \\
\hline Compensatory History & $\begin{array}{l}\text { The absence of women is noted. There is a search for missing women according to a male norm of greatness, excellence of } \\
\text { humanness. Women are considered as exceptional, deviant or 'other.' } \\
\text { Women are added into the traditional structure of the discipline but the structure and methodology are not challenged. }\end{array}$ \\
\hline Bi-Focal History & $\begin{array}{l}\text { Human experience is conceptualized primarily in dualist categories: male and female; private and public; agency and } \\
\text { communion. Emphasis is on a "complementary but equal" conceptualization of men's and women's spheres and personal } \\
\text { qualities. } \\
\text { There is a focus on women's oppression and misogyny. Women's efforts to overcome that oppression are presented. } \\
\text { Efforts to include women lead to the insight that traditional content, structure, and methodology of the disciplines are more } \\
\text { appropriate to the male experience. }\end{array}$ \\
\hline Feminist History & $\begin{array}{l}\text { Scholarly inquiry pursues new questions, new categories and new notions of significance which illuminate women's } \\
\text { traditions, history, culture, values, visions, and perspectives. } \\
\text { A pluralistic conception of women emerges which acknowledges diversity and recognizes that other variables besides } \\
\text { gender shape women's lives, e.g. race, ethnicity, and social class. } \\
\text { Women's experience is allowed to speak for itself. Feminist history is rooted in the personal and the specific; it builds from } \\
\text { that to the general. } \\
\text { The public and the private are seen as a continuum in women's experiences. } \\
\text { Women's experience is analyzed within the social, cultural, historical, political, and economic contexts. } \\
\text { Efforts to reconceptualize knowledge to encompass the female experience. The conceptualization of knowledge is not } \\
\text { characterized by disciplinary thinking but becomes multidisciplinary. }\end{array}$ \\
\hline $\begin{array}{l}\text { Multi-Focal, Relational } \\
\text { History }\end{array}$ & $\begin{array}{l}\text { A multi-focal, gender-balanced perspective is sought which serves to fuse women's and men's experiences into a holistic } \\
\text { view of human experience. At this stage scholars are conscious of particularity, while at the same time identifying common } \\
\text { denominators of experience. They must begin to define what binds together and what separates the various segments of } \\
\text { humanity. } \\
\text { Scholars have deepened understanding of how private as well as the public form a continuum in individual experience. } \\
\text { They search for the nodal points where comparative treatment of men's a women's experiences is possible. } \\
\text { Efforts are made to reconceptualize knowledge to reflect this holistic view of human experience. The conceptualization of } \\
\text { knowledge is not character by disciplinary thinking by becomes multidisciplinary. }\end{array}$ \\
\hline
\end{tabular}

Adapted from "Integrating Women's History: The case of United States History High School Textbooks," by M. K. Tetreault, 1986, The History Teacher, 19(2) p. 215-217. 
The second phase model discussed by Woyshner, the McIntosh model differs from the Lerner/Tetreault model in its phase identification and descriptions. The McIntosh model consists of five phases beginning with "Womanless, all-white history," next is "corrective history" known as the exceptional other history, comparative to the Lerner/Tetreault "compensatory history." In the third phase, "issues history" sexism and patriarchy serve as interpretive frameworks to women's history; this aligns with the Lerner/Tetreault "oppression framework or bi-focal history" phase. McIntosh's fourth phase, “Alternative starting point history” looks at women's lives as history, noting there is nothing "too humble to study." In the final phase, "history is redefined and reconstructed to include women's ways of being, knowing, living and loving” (Woyshner, 2011).

Through the phase model the discourse surrounding women's history is examined, challenged and set on a course for growth and increased inclusion. Poststructuralists "see discourses not as groups of words or sets of signifiers which simply refer to or describe reality...instead discourses are the "practices that systematically form the object of which they speak;" therefore it is only possible for us to think and know through the discourses with which we have access. (Schmeichel, 2011, p. 13). Hence, it is important to examine the language scholars, educators, and curriculum developers use when discussing the inclusion of women's history or women's history itself. As the state of women's history inclusion is discussed word choice become paramount to meaning. It is not exactly accurate to say women were omitted from the historical record, as Minnich (1990) notes, we were excluded (p. 32).

The second framework for bringing gender into the social studies, Woyshner addressed, is the "Care Tradition." The Care Tradition attributed to educational philosopher Nel Noddings, 
recognized that women's contributions throughout history can be encompassed in the world of caregiving, "women have been charged with caregiving — with caring not only for their own families but also for the ill, elderly, and needy in their immediate communities" (Noddings, 2002, p. 51). Noddings' argument includes the notion that boys and girls should both be educated for caregiving as well as breadwinning; students should examine homemaking and caregiving through history, philosophy, art, music and geography; the care tradition promotes the study of social policy and a consideration of the public-private dichotomy so often divided by gender (Woyshner, 2011, p. 266).

Acknowledging the care tradition in women's history is a significant inclusion for feminist pedagogy. Fisher (2001) describes feminist pedagogy as "teaching that engages students in political discussion of gender injustice." It is a collective, collaborative discussion and ongoing process that recognizes women's experience, feelings, ideas and actions. It's goal is to identify and confront oppressive power relations; and, it supports women's political agency by accepting the significance of the private sphere (Fisher, 2001, p. 44).

The third, and for the purposes of this dissertation, most significant framework as delineated by Woyshner is “Social Education.” Woyshner uses Crocco’s definition of social education, "teaching and learning about how individuals construct and live out their understandings social, political, and economic relations... and the implications of these understandings for how citizens are educated in a democracy" (Crocco, 1999, p. 1). According to Woyshner, "social education allows for a broadening of the history and study of social studies because it considers the origins of women's efforts from outside of the content areas of history, geography, and economics" (Woyshner, 2011, p. 267). The National Council for the Social Studies (NCSS) notes the purpose of social education is to "help young people make informed 
and reasoned decisions for the public good as citizen of a culturally diverse, democratic society in an interdependent world" (National Council for the Social Studies, 2010).

There is a clear link between social education and democratic/citizenship education. Educating for democracy requires that social change becomes the impetus for education. Santora (2011) notes that there is a key challenge for educators on "whether democratic social education should emphasize patriotism and the knowledge needed to maintain the status quo or should it promote citizenship for critical thinking and the transformation of selves and society" (Santora, 2011); but what of gender? Crocco (2001) notes "the future of a healthy society may depend on a social studies curriculum that considers these issues [shifting gender roles and greater openness about issues of sexuality] in a more forthright manner" (p. 66).

Democratic education is a "way of being" and serves as a moral imperative for "classrooms that focus on understanding and improving interpersonal and intercultural relationship and the world condition" (Santora, 2011). In Dewey’s seminal work Democracy in Education he regards the educational system as the primary social institution responsible for the moral development of students in preparation for life in a democratic society (Dewey, 1916). Thus, how can social studies be providing democratic education for a democratic society when half the population is excluded from the narrative? Moreover, how is studying the histories of only white, male, Christians be reflective of a democratic society which espouses equality? Dewey, an American pragmatist philosopher, embraced the pluralism of experiences, values and meanings. He believed in social meliorism, the idea that human action can improve the human condition. The point of social education (i.e. history education) in effect is to create good citizens. Yet citizenship education itself is multifaceted and its own purposes provide disagreement among scholars. When we teach students the history of their society and culture 
we are teaching them what we value. Our values are at the core of what we consider a good citizen.

Part of citizenship involves political involvement. A major precept of social education must be to foster a sense of equality for both genders. In a series of studies on attitudes toward women politicians, researchers found that just over a quarter of 14-year-old American students strongly agreed with the statement "women should run for political office and take part in government much the same as men do" and within the sample, females were more likely than males to support such rights (Hahn, 1996, p. 14). Hahn pointed out that there is a continued reluctance of white males to support females holding office, which "might be attributable to a perceived threat that traditional winners — white males — would lose in terms of political and other opportunities" (p. 15). The above statement provides a rationale for gender-balancing the curriculum. Similar to the reasons single-sex classrooms/schools are not beneficial to male students, the research shows single-sex schools are good for girls but bad for boys - both in terms of academic performance and socialization. Female students appear to learn how to interact with and understand males if they have been to single sex schools, whereas male students taught on their own tend to find females more mystifying (Sullivan, Joshi, \& Leonard, 2010). The argument is that if boys are not in classes where girls challenge them and if they don't see girls as competition from an early age, they will not accept females as competition later in life, i.e. in the political sphere or as superiors in their careers. Thus, if learning with female students provides male students better socialization and acceptance of female academic prowess, then learning about female accomplishments and lives can only benefit male acceptance of future female accomplishments. 
Over the years, there have been a number of studies that analyzed student knowledge, skills, and attitudes regarding the social studies. In a National Education Longitudinal Study (NELS) of 1988, “gender differences emerged in students' answers associated with what researchers characterized as 'male themes' (e.g., power, conflict, and control) and 'female themes' (e.g., individual liberty, equality, social consequences of historical change, religion, and food)" (Crocco, 2008, p. 178). The study also showed that males showed more positive attitudes toward history and had greater participation in history oriented extra-curricular activities.

Studies on Advanced Placement (AP) tests have shown similar results. Males did better on multiple-choice portions of the tests and females had superior scores on the free-response portions (Breland, Danos, Kahn, Kubota, \& Bonner, 1994). The study also indicated that females were more likely to take the AP U.S. history exams. A more recent study (Buck, Kostin, \& Morgan, 2002) on social studies AP tests uncovered “differential item functioning” related to gender; "male-oriented content included items associated with business and economics, competition and conflict, sports, fame and high achievement, and politics, among others; while female-oriented content included human relationships, feelings and emotions, personality and behavior, arts and literature, verbal aggression, and religion among others" (Crocco, 2008, p. 178). Including female-oriented content into social studies classes would likely help to prevent the disconnect females have demonstrated with the material. Wineburg (2001) contends The familiar past entices us with the promise that we can locate our own place in the stream of time and solidify our identity in the present. By tying our own stories to those who have come before us, the past becomes a useful resource in our everyday life (p. 5). 
Women's intellectual growth has been stymied by the absence of women from the discourse of history; the male experience has been represented as the human experience.

"Without knowledge of women's past, no group of women could test their own ideas against those of their equals, those who had come out of similar conditions and similar life situations. Every thinking woman had to argue with the 'great man' in her head, instead of being strengthened and encouraged by her foremothers. For thinking women, the absence of Women's History was perhaps the most serious obstacle of all their intellectual growth" (Lerner, 1993, p. 12).

The absence of women from the traditional historical narrative has caused women to appear inferior to men. Historically women have been included in the margins of the textbooks and lessons, usually as a token addition (Holt, 1990). The effect this has on female students has been explored in studies in which the results indicate that females tend to dislike social studies because they feel ignored by the curriculum (Rogers, 1990).

In a study conducted to discover how students "picture the past," Wineburg asked students to draw historical figures, pilgrims, western settlers, and hippies, to determine if students tended to draw their own gender or if there were other implications that drove students to draw more male-centric figures. The results indicated that male students overwhelmingly drew male figures for each of the historical characters; female students varied depending on the historical figure, i.e. pilgrims and hippies were predominantly female, but settlers were $65 \%$ male, an overwhelming difference from the other characters (Wineburg, 2001).

\section{Social Studies Curriculum}

The social studies has been dominated by a "chronological, textbook-centered curriculum" since the beginning of the $20^{\text {th }}$ century (Cruz \& Groendal-Cobb, 1998; Evans, 2004, 
p. 5). Because of this, educators tend to think very little of the curriculum they impart to their students. "Even scholars who make their salaries teaching, usually think about curricular matters beyond their own courses only when they must" (Minnich, 1990, p. 11). Though we take social studies to mean "teaching and learning about how individuals construct and live out their understanding of social, political, and economic relations — past and present — and the implications of these understandings for how citizens are educated in a democracy" (Crocco, 1999, p. 1; Woyshner, 2011) most of the curriculum is designed and implemented by state standards that do not reflect the experiences of women. States and counties adopt textbooks that leave out controversial topics, and eliminate "metadiscourse," the discussion surrounding the author's positionality to the text. Wineburg asserts, "textbooks pivot on what Roland Barthes called the 'referential illusion,' the notion that the way things are told is simply the way things were...no author confronts the reader; instead, a corporate author speaks from a position of transcendence" (Wineburg, 2001).

Minnich (1990) questioned how it is that society has so effectively held knowledge of, by, and about women outside that which has been and is passed on, developed, and taught (p. 12). Curriculum theorists argue that the creation and development of curriculum is a normative process, that is, curriculum presents cultural truths and values (Crocco, 2008, p. 180). Clearly throughout history, men and women's experiences have been markedly different, yet through the practice of history education women's history has been folded into male history creating an erroneous depiction of the past. “Men's story gets told; women's gets left out. Thus not only do women's lives not count in the story of civilization, but men's lives 'stand in' for women's lives, essentially rendering women invisible to history" (Crocco, 1997, p. 32). Though social studies organizations have suggested that teachers should include women and gender into their courses, 
it is unclear to what extent they are doing so, especially if they are following state standards and primarily using county approved textbooks.

The National Council for the Social Studies (NCSS) includes only one standard that mentions gender: "Assist learners to describe how family, religion, gender, ethnicity, nationality, socio-economic status and other group and cultural influences contribute to sense of self." Individual state standards are similar in nature; for example, the Florida standards include the study of women in U.S. history since 1880, as if there were no women contributing to society before that date. The standard itself focuses on "the contributions of women... who have worked to achieve equality and improve individual lives" thus women are only worthy of inclusion if they contributed to their own fight for political equality (Cruz \& Groendal-Cobb, 1998;

Scheiner-Fisher \& Russell, 2012).

According to Joan Wallach Scott (1997), "the conception of curriculum standards in American and world history had the effect of codifying a political approach that 'makes the systematic inclusion of women difficult"” (as cited in Hahn et al., 2007). This approach underscores the development of nation-states, and since women have been minimally involved in state governance, this type of method manages to eclipse women's role in history.

In the Handbook for Achieving Gender Equity through Education the authors assert that attention to gender in the social studies has waned for a number of reasons in recent years:

- Decreased emphasis on social studies as a non-tested subject;

- Assumption that gender equity has been achieved;

- Misplacement of gender issues under the umbrella of multiculturalism; and

- Lack of federal funding for gender-related research (Hahn et al., 2007). 
The fact that there is waning attention to gender in the social studies is concerning because social studies offers a uniquely appropriate venue for addressing issues of gender bias, sexism, and women's issues in relation to other curriculum areas. Students should learn about women's participation in American life; about women's involvement with the abolition and anti-lynching movements, varied labor movements, peace movements, and other reform efforts. Research shows that most students learn about the Seneca Falls Convention and the passage of the $19^{\text {th }}$ Amendment to the U.S. Constitution. However, gender related themes such as the movement for birth control, the defeated Equal Rights Amendment (securing equality under the law for women) and Title IX of the 1972 Amendments to the Higher Education Act (ensuring women could not be excluded from participation in educational programs or activities receiving federal financial aid) are not covered (Hahn et al., 2007).

\section{Textbooks}

Throughout the history of social studies education, the male-oriented paradigm has dominated both textbooks and other curriculum materials (Crocco, 1997, 2008; Schmeichel, 2011; Tetreault, 1986b). The Handbook of Research in Social Studies Education notes that creating and developing curriculum is a normative process and when women are left out of the narrative, "students get the message that women's stories, issues, and concerns are unimportant for history" (Crocco, 2008).

If political and economic history crowd out social history and, by extension, women's history, then students get the message that childbearing and childrearing, subsistence agriculture, and the building of a social order, and the care and maintenance of communities have had little significance over time (Crocco, 1997). 
One way of circumventing this problem is shifting the focus from military, economic, and political history toward social history that includes the narratives of the private as well as the public spheres.

In the Sex Equity Handbookfor Schools, the authors note that U.S. history textbooks tend to include the following information on women:

Women arrived in 1619. They held the Seneca Falls Convention on Women's Rights in 1848. During the rest of the nineteenth century, they participated in reform movements, chiefly temperance, and were exploited in factories. In 1920 they were given the vote. They joined the armed forces during the Second World War and thereafter have enjoyed the good life in America (Gollnick, Sadker, \& Sadker, 1982; Trecker, 1973).

In her analysis of high school textbooks, Trecker (1973) showed that many omit women of importance, while also minimizing the legal, social, and cultural inequities they faced. The authors of the textbooks tended to portray women in submissive roles and excluded women from topics discussed. Trecker provides this example, "while only a few women could possibly be included in discussions of diplomacy or military tactics, the omissions of dance, film, and theater in discussions of intellectual and cultural life assures the omission of many of America's most creative individuals" (p. 133). Trecker's study found that wherever possible, textbook authors selected male leaders, and quotes from male spokesmen. "Even in discussions of reform movements, abolition, labor - areas in which there were articulate and able women leaders - only men are ever quoted" (Trecker, 1973). When topics which would have easily lent themselves to including women's points of view, such as life on the frontier, women were viewed through the recollections of men. 
Though representation of women in textbooks has increased from 3.2\% in the 1960 's to $10.6 \%$ in the 1990's (Clark, Ayton, Frechette, \& Keller, 2005), more inclusion may not provide actual gender-balancing. Implanting women into the established canon is problematic - the "add women and stir" method simply mentions females for achievements that would go unrecognized if the subjects were male, as Noddings (1992) notes, that is demeaning to women and trivializes the history under examination (pp. 230-231). Moreover, "the now-found 'lost' women seemed to prove something that needed proving yet again — that women are by no means and in no way inferior to men—we had not, in fact, learned much about women" (Minnich, 1990, p. 27).

A study of civics textbooks (2001) showed that women were mentioned 258 times compared to 1,899 times for men. The women mentioned included Abigail Adams and Eleanor Roosevelt. Only a third of the textbooks discussed the disparity between men and women in politics, but all of them included a section on the suffrage movement, the only women's history topic that virtually all American students learn about.

\section{Gender Bias}

According to Gollnick, Sadker and Sadker, there are six types of gender bias in both textbooks and in the classroom (Gollnick et al., 1982, p. 94). These include:

1) Invisibility or underrepresentation

2) Stereotyping

3) Selectivity and imbalance (focus on aspects of history such as political and military that have little female presence)

4) Unreality in instructional material (spotless housewife)

5) Fragmentation and isolation (marginalization)

6) Linguistic bias: caveman, mankind, forefathers etc. (Gollnick et al., 1982) 
Gender bias exists in the world and is apparent in school systems. Schools have advanced since the days of teaching explicit gender roles and leaving women completely out of the content area, however, in less apparent ways women are still relegated to the margins or spoken of as secondary actors in many crucial fields. Students today are besieged by the media with images of female beauty and male macho; "blatant sexist images inundate movies, television, and advertising, but it is even more subtle sexist messages that can shape how we view our world" (Sadker et al., 2009).

The book Still Failing at Fairness includes a section "The Costs of Entitlement” which discusses the effect bias against females has on male students. When asked what it would be like to be born a member of the opposite sex, female students responded with positive possibilities: power, athleticism, wealth, and strength. Male students ...were repulsed at even the idea of being born a female, or living in a female body, or facing female life choices. A significant percentage of the boys said they would kill themselves, that they would rather be dead than female. Male entitlements are obvious even to children (Sadker et al., 2009, p. 21).

Thus, according to Sadker et al., not only were female students aware of male privilege/entitlements, but male students were seemingly even more aware of the lack of such entitlements for females, even if they were not able to point to specific privileges they themselves enjoyed.

\section{Gender Balance/Gender Equity}

In 1986, Tetreault conducted a study to answer the question, "What impression does viewing our history from a male perspective with the authority of the school behind it, make on our students?" She found that because the curriculum tends to suggest that women's activities in 
the public spheres are acceptable when they either champion male activities or are a broadening of women's supporting role within the family. This reinforces the idea that women's virtue lies in self-sacrifice. Adolescent females thus struggle with the ethic of self-sacrifice in contrast to the concept of their own rights (Tetreault, 1986b).

“Since the women's movement of the 1960 's, calls from national organizations and state legislatures for the infusion of women's studies into the K-12 courses have steadily increased. Scholars, curriculum developers, and learned societies have also called for a more genderbalanced curriculum" (Cruz \& Groendal-Cobb, 1998). However, there are a number of reasons this gender-balanced curriculum has not emerged. One reason is that teachers often have a lack of content background, "Teachers whose own education has emphasized these traditional perspectives are often reluctant to address topics from social and women's history with which they are not familiar" (Crocco, 1997, p. 32). Yet, students should learn about women's participation in American life.

Gender equity has been defined as follows: "to be fair and just toward both men and women, to show preference to neither, and concern for both" (Klein et al., 2002). If gender equity was prevalent in social studies classrooms, "the histories, narratives, and lived experience of boys and girls, men and women, would be represented equally and accurately in social studies textbooks, supplemental curricular materials and classroom instruction” (Hahn et al., 2007). Furthermore, outcomes related to practiced gender equity could

Foster knowledge and dispositions essential to $21^{\text {st }}$ century multicultural, democratic citizenship by promoting gender equity and by developing in students of both genders attitudes and understandings supportive of men's and women's 
equal participation in all sectors, careers, and institutions of society, including leadership in government and business (Hahn et al., 2007, p. 336).

\section{Recommendations for Incorporating Women's Voices}

There are a variety of recommendations throughout the literature for incorporating women's history into the classroom. Clearly, changes to textbooks and curriculum are widely suggested. More attention to and direct instruction about frameworks, such as separate spheres, social education, or the phase models could be incorporated into class discussions (Woyshner, 2011, p. 271)

Clio in the Classroom: A Guide for Teaching U. S. Women's History provides one of the only handbooks with key content, concepts and teaching strategies that "move beyond the notion of women's history as a compendium of 'firsts'," (Berkin et al., 2009, p. 3). The editors include strategies for redesigning history courses using feminist pedagogy, oral histories, threedimensional objects (realia), primary sources, and visual images. Many of these suggestions are common throughout the literature.

Another set of recommendations comes from the Handbook for Achieving Gender Equity through Education; the authors recommend that social studies educators:

- Ensure that substantial attention is devoted to gender in curriculum in order to present an accurate view of gendered human experience in history and contemporary society;

- Social studies curriculum developers give more attention to the diverse experience of women and girls by class, race, ethnicity and sexual orientation;

- The notion of gender equity be expanded to include all individuals; men and boys are gendered as well as women and girls; 
- Connections between universities and colleges and K-12 social studies educators be strengthened to support curriculum transformation based on new knowledge;

- Policy makers, practioners, and scholars address the need to look at structural problems in school systems and classrooms that create barriers to delivering gender-equitable social studies; and

- Continue research along several lines of inquiry - including among others - the benefits of gender inclusion in social studies in the elementary grades, gender and technology, and teacher and classroom practices (Hahn et al., 2007).

These recommendations encompass best practices from years of research. Because gender equity reforms from the 1970's and 1980's (including textbook revisions, teacher preservice and in-service trainings, and the use of feminist teaching practices) have stalled, the authors note, "this phenomenon of slowed reform has created urgency for gender equity in the social studies; we must compensate for lost momentum as much more work remains to be done" (Hahn et al., 2007, p. 350).

Feminist teaching practices such as "empowering students, decentering authority in the classroom, creating cohesive learning communities, and honoring students' diverse experiences" (Goldberg, 2009, p. 210) are present in much of the literature, yet they are called for in a much more subdued manner than most of the other recommendations. Teachers who utilize feminist teaching practices are often faced with the challenge of demonstrating their intelligence and competence while also fostering community learning (Copp \& Kleinman, 2008, p. 102). Though many instructors may find student-centered teaching methods challenging Copp and Kleinman point out, "If we give up on student-centered teaching methods-failing to practice what we 
teach - then students are less likely to actively engage with feminist ideas. They may see us as militant, shoving feminist messages down their throats" (Copp \& Kleinman, 2008). 


\section{CHAPTER 3: METHODOLOGY}

The intention of this study is discover the motivation for why some teachers exceed the expectations of the required curriculum to incorporate women's history/perspectives into the traditional history framework. Moreover, I set out to discover how these teachers incorporate said topics into their lessons. Since this study is feminist in nature, that is, as Lather (1991) states, it seeks to "correct both the invisibility and distortion of female experience in ways relevant to ending women's unequal social position" I utilized feminist theory to guide the study (p. 71).

\section{Research Questions}

1. Are teachers incorporating women's history/perspectives in their lessons?

2. How do teachers incorporate women's history/perspectives into their lessons?

3. What factors contribute to teachers including women's history/perspectives in their classes?

\section{Feminist Research Strategies}

Stewart (1994) laid out seven feminist strategies to study women's lives; these strategies were utilized to determine what factors contributed to teachers integrating feminist structures into their classes. Stewart noted that when studying women (and for this study, issues pertaining to women) these seven strategies are key:

1. Look for what's left out. Feminist theory would lead us to expect that the things that will be missing will be the things that those who are not women are not likely to be able to know and things that those who have a stake in the status quo are unlikely to what to know (p. 18). 
2. Analyze your own role or position as it affects your understanding of the research process. Stewart urges researchers to consider consciously and methodically the ways in which one's demographic and ideological individualities may affect one's work. She states that we must be careful when interviewing living women to build in opportunities to tell them what we are thinking so they can tell us how they see us and where we have gone wrong (p. 19).

3. Identify women's agency in the midst of social constraint. Stewart emphasizes that researchers must recognize agency, one is never only oppressed, and people in subordinate status make choices and resist oppression (p. 21).

4. Use the concept of "gender" as an analytic tool. Researchers should understand that gender is a social construct, and the concept of what it means to be a woman (or man) varies (p. 23).

5. Explore precise ways in which gender defines power relationships and in which power relationships are gendered, noting specifically, that dominance precedes difference (p. 25).

6. Identify other significant aspects of an individual's social position and explore the implications of that position (i.e. race, class, sexual orientation) (p. 27).

7. Avoid the search for a unified or coherent self or voice - diverse and multiple selves and identities are included within a single person (p. 29).

I've included these strategies because I interviewed teachers about their lives independent from their classroom practices to uncover the factors that led to each of them including women's perspectives when the curriculum does not require them to do so. 


\section{Research Design}

A multi-layered qualitative methodology was employed for this study using survey and phenomenological approaches. This study included a survey to discover what percentage of respondents claimed to incorporate women's history and women's perspectives into their classes, from this survey, individuals were identified to participate further. Additionally, qualitative data was taken from a series of two meetings: one interview and one classroom observation in order to understand the process with which each participant incorporated women's history/perspectives into their classroom practice.

A collective case study design was used to show differing perspectives on the research topic. Because I was looking at the reasons why certain teachers incorporate women's history/perspectives, I conducted this study using a phenomenological approach.

\section{Case Studies}

Creswell (2007) notes that case study research involves the study of an issue explored through one or more cases within a bounded system (i.e. a setting or context) (p. 73). He goes on to say that "case study research is a qualitative approach in which the investigator explores... bounded systems (cases) over time, through detailed, in-depth data collection involving multiple sources of information, and reports a case description and case-based themes."

Yin (2009) remarks that case studies should be used when research focuses on contemporary events when the researcher is asking " how and why," and when no control over behavioral events is required (p. 8). Yin notes that case studies attempt to "illuminate a decision or set of decisions: why they were taken, how they were implemented and with what result" (p. 
17). This study aimed to do exactly that, to understand why certain teachers had made the decision to go above and beyond the required curriculum to incorporate issues of gender and women's voices into the traditional history framework.

\section{Phenomenology}

Phenomenology describes the meaning for several individuals of their lived experiences of a concept or phenomenon (in this case, the phenomenon under study was teachers going above and beyond the required curriculum to integrate women's perspectives in their history classes) (Creswell, 2007, p. 57). Phenomenology is steeped in philosophical roots that include the necessity of suspending judgments about what is real until they are founded on a more certain basis; the intentionality of consciousness - the idea that consciousness is directed toward an object; and, the refusal of the subject-object dichotomy - the reality of an object is only perceived within the meaning of the experience of an individual (Creswell, 2007, p. 59).

There are two types of phenomenology, for this study I employed transcendental or psychological phenomenology since it is "focused less on the interpretation of the researcher and more on a description of the experience of participants" (Creswell, 2007, p. 59).

\section{Research Setting}

The school district where the research was conducted is one of the largest school districts in the nation. There are 175 schools serving nearly 181,448 students in Orange County Public Schools (OCPS), of those 175, 53 are traditional (non-charter, non-K8) secondary schools with approximately 825 secondary social studies teachers. The research was completed at multiple school locations. Interviews and observations were conducted at each of the six participants' schools. 


\section{Population and Sample}

A purposeful, theoretical sample was generated for this study. Such a method allowed me to select "people on the basis of their potential manifestation or representation of important theoretical constructs" (Patton, 2002, p. 238). Thus, a small sample was purposefully selected to conduct an in-depth study of the phenomenon in question. I aimed to employ maximum variation in my sample to represent diverse cases and to fully describe multiple perspectives (Creswell, 2007).

Secondary social studies (history) teachers in Orange County received a survey soliciting their participation in the research study. The survey asked teachers if they incorporated a variety of multiple perspectives into their teaching practices. Included in the list of multiple perspectives were women's voices/perspectives. The last part of the survey requested participants to provide contact information if they consented to be contacted for further participation. After compiling the data from the survey, I contacted any teachers who selfidentified as including women's voices once a week or more. Originally I was hoping to find teachers who specifically taught U.S. history, which in the case of Orange County was be $8^{\text {th }}$ and $11^{\text {th }}$ grade, however, my sample included teachers of psychology, world history and civics as well.

Since this was a qualitative, phenomenological case study, six participants comprised my sample. This is consistent with other phenomenological case study research. 


\section{Data Collection}

\section{IRB Approval}

Before conducting research, a proposal was submitted the Institutional Review Board at the University of Central Florida to ensure ethical matters, such as confidentiality, were considered and observed. Initial consent will be granted by participants who fill out the survey and provide contact information if they wish to be contacted for further participation.

\section{Data Collection}

A multi-layered qualitative approach was used for addressing this study's research questions. In order to ascertain the percentage of social studies teachers who include women's history/perspectives into their curriculum, a survey was conducted inquiring which perspectives are included in their lessons. From this survey, participants who claimed to include women's voice in their lessons more once a week or more, were identified to contribute to the rest of the research. Once participants were identified, I conducted phenomenological interviews and classroom observations. All names have been kept confidential, and pseudonyms have been used in subsequent chapters.

\section{Interviews}

Seidman (2006) notes, "people's behavior becomes meaningful and understandable when placed in the context of their lives and the lives of those around them" (p.17). The interviews focused on three topics beginning with a focused life history, in which I asked participants to tell me as much as possible about herself/himself in light of the topic up to the present time (p. 17). They were asked to reconstruct their early experiences in their families, in school, and experiences that led them to be participants in the study (p. 17). 
The second part of the interview focused on the details of the experience-here they were asked to concentrate on the details of their present lived experience in teaching about women's history (p. 18). Rather than asking participants about their opinions related to the topic, they were asked the details of their experience upon which their opinions were built (p. 18).

The third part of the interview asked participants to reflect on the meaning of their experience. This interview addressed the intellectual and emotional connections between the participants' work and life (p. 18). In this stage, participants were asked to look at how the factors in their lives interacted to bring them to their present situation (p. 18). Seidman's three-stage interview process allowed me to build upon and explore participants' responses such that they can reconstruct their experiences within the parameters of the study.

\section{Observations}

All but one of the participants was observed in his or her classroom due to the fact that he decided not to participate further than the interview (more on this in Chapter 4). The observations were planned since I was looking for how participants incorporate women's perspectives Although this ran a risk of participants planning lessons specifically to meet the needs of the study, this posed less of a problem than unplanned visits in which participants did not at all meet the needs of the study. I took on the role of nonparticipant observer, meaning that I observed as an outsider and did not take part in the classroom activities. During these observations, I took both descriptive field notes and reflective field notes using an observational protocol that allowed me to summarize chronologically the flow of activities in the classroom (Creswell, 2007, p. 135).

During the observations, I looked for how participants incorporated issues pertaining to gender and women's history into their lessons. I then collected and analyzed any materials they use during the lesson as well. 


\section{Data Analysis}

In order to best understand the data, I transcribed each interview. After transcribing, I used Glesne's (2011) model of early data analysis which examined field notes and transcripts using rudimentary coding schemes. I then created codes and a codebook to determine which themes developed. Semiotics was also examined, especially during classroom observations. Through semiotic analysis, I was able to examine how signs and symbols constructed meaning. According to Glesne, researchers have "inquired into ideologies and systems of power in order to suggest ways in which certain signs get taken as 'natural' —as the way things are or should be.” (p. 187). Another method of analysis I employed was thematic analysis in which I focused on searching through the data for themes and patterns (Glesne, 2011, p. 187) though thematic analysis, early data analysis, and rudimentary coding schemes will be used together.

Using phenomenological data analysis, I, as Moustakas (1994) suggests, described my personal experiences with the phenomenon, developed a list of significant statements, grouped statements into themes, provided a "textural description" which included what participants experienced, provided a "structural description" which described how the experience happened, and finally wrote a composite of both the textural and structural descriptions (Creswell, 2007, p. 159). I chose these forms of analysis because they lent themselves best to the data collection procedures and purposes of study.

Following the initial coding phase, I applied Tetreault's "Stages of Thinking About Women in History" as the framework of how each participant included women's history in her/his classroom. This framework contains five phases: Male History (in which the absence of women is not noted), Compensatory History (the absence of women is noted; there is a search 
for missing women according the male norm of greatness), Bi-focal History (focus on women's oppression and misogyny; women's efforts to overcome oppression are presented), Feminist History (women's experience is analyzed within the social, cultural, historical, political, and economic contexts), and Multi-focal/Relational History (seeks to fuse women's and men's experiences into a holistic view of the human experience)(Tetreault, 1986a). Thus, each observation and interview provided data as to where participants fell along the continuum of women's history inclusion.

\section{Positionality}

In The Feminist Classroom, Maher and Tetreault (2001) describe "the idea of positionality, in which people are defined not in terms of fixed identities, but by their location within shifting networks of relationships, which can be analyzed and changed" (p. 64). Glesne (2011) states, "Positions tend to refer to aspects of one's person that are not necessarily embodied in the person and include both ascribed characteristics (nationality, ancestry) and achieved characteristics (educational level, economic level, institutional affiliation, etc.)" (p. 157).

Feminist and phenomenological research requires that the researcher state her positionality. Like other feminist researchers, I see gender as a basic organizing principle that shapes the condition of my life. I am deeply invested in feminism. As a teenager, I joined the National Organization for Women (NOW); I served in leadership roles in that organization while in college, then in both my local and state chapters. I grew up in a household where my father always told my sister and me not to depend on our looks, and that girls could do anything boys could do. He talked about his accomplishments in a way that made me believe I could follow his example. My mother supported all of my intellectual pursuits, believed in me, and always told 
me I could accomplish anything I set out to do. It wasn't until I became an adolescent that I allowed societal expectations to inform my accomplishments. In my early teen years, I thought girls were supposed to be cute and giggly, they weren't supposed to excel in school, so I looked for other ways to get attention, although during this time I developed a great sense of humor, it did not help my school work.

My family moved to Florida during my junior year of high school. Because I did not have any friends, I focused most of my time on my schoolwork, there was no one to impress so I stopped making jokes in class - it was during this time that I discovered I was smart. I was making excellent grades in school and I finally realized that I could be whatever I wanted, and the first step was coming to the realization that I had pigeonholed myself into what I believed a girl should be.

I include this story because in social studies classes, I never saw women as actors; they were, if included at all, in supporting roles to the men who accomplished real history. Having taken history classes in high school I thought of myself as a student of history, never as a possible actor. Although most of my teachers were female, the only example of women's history I was exposed to was the suffrage movement. This allowed me to see women as actors in history for the first time, thus propelling me toward becoming a women's rights activist. I imagine if girls were exposed to more women's history from an earlier age-they would see themselves in the story, and can imagine themselves as more than a wife to an important man. It is that assumption that has led to this research.

My positionality as it relates to the research procedures themselves is this: I believe that qualitative research can provide powerful insight into the motivations of individuals in a way that quantitative research cannot. Case study research, using observations and interviews, allowed 
me to understand why decisions were made, how they were implemented, and the final results (Yin, 2009, p. 17).

Glesne includes Glazer's (1982) definition of reciprocity as “the exchange of favors and commitments, the building of a sense of mutual identification and feeling of community" (p. 50). Glesne notes that researchers often feel indebted to their participants because what they are offering is invaluable to the project. She comments that participants value "the means to be grateful, by acknowledging how important their time, cooperation and words are; by expressing your dependence upon what they have to offer; and by elaborating your pleasure with their company" (p. 178). For this study, my reciprocity with my participants was my obvious gratitude for their time and information. I gave them the opportunity to feel like what they do in their classrooms is important, and makes a difference to people beyond the classroom walls. I believe that this study can be useful to a broad educational audience; and their stories will contribute to the literature on the inclusion of women's voices in the social studies curriculum.

Throughout this study, I aimed to foster my own reflexivity through which I was able to critically reflect on how participants, setting, procedures, and I (as researcher) interacted and influenced each other (Glesne, 2011, p. 151). I examined my own biases, subjectivity and the appropriateness of research methodology, including interpretations made and representations produced, as the study progressed (Glesne, 2011, p. 151). 


\section{CHAPTER 4: FINDINGS AND DISCUSSION}

This research study examined the inclusion of women's history and women's perspectives in the secondary social studies classroom. The overall goal was to determine why some teachers go above and beyond the required curriculum to include women's perspectives when it is not required by the curriculum. In this study, I set out to answer the following the primary research questions:

1. Are teachers incorporating gender and women's history in their lessons?

2. How do teachers incorporate gender and women's history into their lessons?

3. What factors contribute to teachers including gender and women's history in their classes?

After sending out 689 surveys, with three follow-up emails, to secondary social studies teachers in Orange County Florida, I received 75 responses, of those, only 63 were complete. From the survey data, I was able to identify 16 possible participants; however, due to a variety of circumstances (no response to email, unfinished survey, or refused further contact) six teachers were eligible and agreed to participate. Thus, six interviews were completed, as were five classroom observations (one participant, Jeffery Emerson, decided not to proceed further in the study after the interview). From that data, 111 pages of transcription were derived and from those 111 pages, 435 significant statements were found, leading to the determination of 26 themes, sorted into four broad categories: participants' background, beliefs, ideas of self, and classroom practices. 


\section{Survey Data}

The first form of data came from the survey. Participants were asked about their inclusion of a number of minority voices including women voices. This was done as to not cause bias in their reporting. Question six read: “Do you include women's voices in your social studies lessons?" Those who answered "Yes" were piped to a question that asked how often they included women's voices; those who answered "No" were piped to a question that asked why they did not include women's voices. The survey data was critical to answering research question number one, “Are teachers incorporating gender and women's history in their lessons?"

Table 2: Inclusion of Women's Voices Survey Question

Do you include Women's voices in your social studies lessons?

\begin{tabular}{|ll|r|r|r|r|}
\hline & & Frequency & Percent & Valid Percent & $\begin{array}{c}\text { Cumulative } \\
\text { Percent }\end{array}$ \\
\hline \multirow{2}{*}{ Valid } & Yes & 64 & 85.3 & 91.4 & 91.4 \\
& No & 6 & 8.0 & 8.6 & 100.0 \\
Missing & Sotal & 70 & 93.3 & 100.0 & \\
Total & & 5 & 6.7 & & \\
\hline
\end{tabular}

From the survey, it is apparent that over $91.4 \%$ of secondary social studies teachers claim to incorporate women's voices. However, only $25 \%$ claim to incorporate women's voices once a week or more, with the greatest percentage, $46.9 \%$, claiming only to incorporate women's voices once a month or less. 
Table 3: Frequency of Inclusion

How often do you include Women's voices in your lessons?

\begin{tabular}{|c|c|c|c|c|c|}
\hline & & Frequency & Percent & $\begin{array}{l}\text { Valid } \\
\text { Percent }\end{array}$ & $\begin{array}{l}\text { Cumulative } \\
\text { Percent }\end{array}$ \\
\hline \multirow{8}{*}{ Valid } & $\begin{array}{l}\text { Less than Once a } \\
\text { Month }\end{array}$ & 9 & 12.0 & 14.1 & 14.1 \\
\hline & Once a Month & 21 & 28.0 & 32.8 & 46.9 \\
\hline & 2-3 Times a Month & 18 & 24.0 & 28.1 & 75.0 \\
\hline & Once a Week & 8 & 10.7 & 12.5 & 87.5 \\
\hline & 2-3 Times a Week & 6 & 8.0 & 9.4 & 96.9 \\
\hline & Daily & 2 & 2.7 & 3.1 & 100.0 \\
\hline & Total & 64 & 85.3 & 100.0 & \\
\hline & System & 11 & 14.7 & & \\
\hline Total & & 75 & 100.0 & & \\
\hline
\end{tabular}

Table 4: Reasons for Non-Inclusion

Why do you not include Women's voices in your lessons?

\begin{tabular}{|ll|r|r|r|r|}
\hline & & Frequency & Percent & Valid Percent & Cumulative Percent \\
\hline \multirow{4}{*}{ Valid } & Not required & 3 & 4.0 & 50.0 & 50.0 \\
& Not enough time & 2 & 2.7 & 33.3 & 83.3 \\
& Other & 1 & 1.3 & 16.7 & 100.0 \\
Total & 6 & 8.0 & 100.0 & \\
Missing System & 69 & 92.0 & & \\
Total & 75 & 100.0 & & \\
\hline
\end{tabular}

Only six teachers surveyed indicated that they did not include women's voices in their lessons; half of those due to it not being required in the curriculum and the other half due to time constraints (although one person indicated "other," s/he explained in the write-in box that time was the main cause). 
Table 5: Gender of Survey Participants

What is your sex?

\begin{tabular}{|ll|r|r|r|r|}
\hline & & Frequency & Percent & Valid Percent & $\begin{array}{c}\text { Cumulative } \\
\text { Percent }\end{array}$ \\
\hline \multirow{2}{*}{ Valid } & Male & 27 & 36.0 & 42.9 & 42.9 \\
& Female & 36 & 48.0 & 57.1 & 100.0 \\
Missing & Total & 63 & 84.0 & 100.0 & \\
Total & & 12 & 16.0 & & \\
\hline
\end{tabular}

Demographic data on participants showed that $57.1 \%$ of valid respondents were female, however, of those who elected to participate further in the study, only one was female. This will be discussed in chapter 5 . 
Table 6: Interview Themes

\begin{tabular}{|c|c|}
\hline Broad category & Theme \\
\hline Early life/ background & $\begin{array}{l}\text { - Military } \\
\text { - Traditional family (nuclear) } \\
\text { - } \text { Experiencenced diversity growing up } \\
\text { - Surrounded by strong women } \\
\text { - Their own teachers } \\
\text { - What they were taught }\end{array}$ \\
\hline Beliefs & $\begin{array}{l}\text { - Awareness of exclusion and controversial nature } \\
\text { - } \text { of including women's history/perspectives } \\
\text { - } \text { Spirititual } \\
\text { - Gender norms } \\
\text { - Feminism } \\
\text { - Thoughts about females } \\
\text { - Paternalism } \\
\text { - Feelings about including women's perspectives } \\
\text { - } \text { African-Americans } \\
\text { - Pop culture }\end{array}$ \\
\hline Ideas of Self & $\begin{array}{l}\text { - Personality traits } \\
\text { - Minority male in majority female profession }\end{array}$ \\
\hline Classroom Practices & $\begin{array}{l}\text { - Usefulness of lessons } \\
\text { - Resources used } \\
\text { - Plans for future classroom practices } \\
\text { - Teaching practice } \\
\text { - Women's perspectives/voices included } \\
\text { - Student desires }\end{array}$ \\
\hline
\end{tabular}




\section{Amy Wiggins}

I interviewed Amy at her school during her planning time, which was first period. Amy and I had attended classes together during our Masters degrees, so there was a small degree of familiarity. Amy was the sole female who agreed to take part in this study beyond the survey. She is Caucasian, in her mid-thirties, and grew up in Mississippi with both her mother and father. Like many of the participants, Amy comes from a military family. She herself was also in the military, which had a profound impact on her educational goals and beliefs about women's place in the world. Of her background she said

Well my background is pretty normal. Military. I went to school at UCF and I was raised in the south. I was born and raised in Mississippi and then I traveled the world in the military then I went to grad school at UCF and I'm here teaching. This is my third year teaching.

When asked about her past in light of the topic under study, for her to reconstruct any experiences she had that may have contributed to incorporating women's history into her lessons, she attributed that to her mother:

Oh Lord, that's a big question. It would probably be my mother. My mother was a very self educated, strong, alpha woman I would say. She was the figure for me growing up.

She said that her parents were equals in the home and acted "together" throughout her upbringing. This is all she mentioned about her parents. Her focus for the interview seemed to revolve more around her current classroom practices and the policies which govern them.

When asked about her own education and possible inclusion of women's perspectives, Amy was very critical of her own teachers and their pedagogical practices. Specifically, when 
asked whether she remembered having women's history brought into her classes while she was in school, Amy responded in the negative:

No, like through high school, things like that, no. Our history teacher back then I hated history. Our history teacher was the normal. He would probably tell a story or two. There was not a lot of [inclusion of women], I remember in world history I think it was $7^{\text {th }}$ grade for me or something like that; they talked a lot about gods and goddesses of Greece. That's all I can remember but no, there wasn't like even the iconic woman figure that stand out in history like Earhart, I didn't learn that much through a class. I learned it through television and things like that.

As a follow-up question, I wondered what other women, besides Amelia Earhart, Amy was familiar with as a student. She responded that she was more familiar with fictional characters, like Scarlett O'Hara, who dressed up as for three or four Halloweens in row. When asked why she had such an affinity for Scarlett O'Hara, Amy said I just like her. I like the movie, I like the dresses. I was very; I guess you could say high maintenance at a young age.

Amy indicated that she had a sense of femininity, and that she valued the traditional roles of women.

Of her own schooling, Amy enjoyed English class more than History. She found history boring, and said she had all the boring coaches as teachers. Her only memorable project was a book report she did on Dracula: 
I chose Dracula, the real man based on the movie because I think the movie was coming out at that time or somewhere around there. That's about it. That's all I remember from high school. We never did anything.

Since Amy did not have a memorable high school experience, I wondered what drew her to teaching, and especially teaching history, so I asked her about her college experience.

Well it depends on what college we're talking about. I got my first degree from Southern Miss and it went from 1995-2000 and not really [on was she exposed to women's history or perspectives]. I did world history, world civilizations back then because I got my degree in business so all I needed was 2 so that's what I did - I took World Civilization 1 and 2 and he just sat there and talked for hours and that was it. I didn't get interested in history until I was in the military and I started reading biographies and then I would see people on TV or whatever and I'll be like "is that a real person" and I started researching it myself. I was an instructor in the military and I decided "why don't I get out and teach" so here I am.

I asked Amy about the biographies she read, she remembered reading about Benjamin Franklin and Ernest Hemmingway, but did not remember ever choosing to read a biography about a woman. She discussed taking a class on Scientific Women in History, which she hated, because she thought she was going to be taking a "Women in History"

It was one of the worst classes that I took. I thought it was woman in history but it was a scientific woman in history so it was about Madam Curie. That's the only one that sticks out of my head now in that class. 
As a teacher, Amy attributes her inclusion of women's history/perspectives to a number of factors. First, Amy points to the current version of her $6^{\text {th }}$ grade World History textbook, which has a few paragraphs about women in each of the ancient cultures they study.

Second, she credits her students' curiosity about women and minorities in history. Well these textbooks make it really easy. But a lot of students, they want to know, like "well what did the women do?" I hear that a lot, because the way I kind of structure my classes is we start on an area of the ancient world, we talk about the geography, of course; and then we go into the timeline of it, and usually at the end we talk about the culture and roles of men and women and stuff like that and they want to know; like how were the woman treated, what did the kids do? If I don't say anything before then, they'll ask. But I do see that a lot of my students get aggravated because most of the ancient civilizations we talked about do not talk about minorities - like "where's all the black people?" I get that a lot and I'm like "they're mainly a nomadic tribes and we're here talking about the first civilizations" so I try to relate it to that. But they do get aggravated because they're like "were we here yet?" It's a touchy subject but in the book, every civilization has a page or two that's telling you the roles of woman. They're getting better at it but they don't have a lot of standout woman that they remember unless it's the goddesses and Cleopatra. That's about it, unfortunately.

Amy was the only teacher involved in this study that explicitly tied her inclusion of women's history/perspectives to the explicit desires of her students to learn about women's history. Though other participants noted that they include women's history/perspectives for the benefit of their students, none indicated that their students showed an innate desire to see reflections of 
their own voice included. Amy believes it is easy for her to consider including women's history because she is a women.

I'm a woman,[so] in my mind I'm always like, "what would I be doing?" And the students want to know that too, like in class [they ask] "What would I be like Ms. Wiggins, in the social class structure?" And I'm like, "Well you might be like me, the lower middle class." But they do want to know. I try to put in females, I think it comes naturally for me.

Amy's rationale for including women's history points to the inclusion of social history, rather than solely military or political history. She talked about bringing in images of tools women used in ancient Egypt, and focusing on what life would be life for her students if they lived back then.

I kind of like to show them how good we have it now compared to what most women had [back then]. I like to show them, like the woman that married young; they had babies with them in the house. They couldn't even go outside and supervise. They [the students] see that and they see how much we have moved forward...they like to see that, and they like to say, "I wouldn't do that" or "that wouldn't happen with me!"

Much of what Amy says she includes in her lessons centers around a comparison model, how life back then differed from life today. She finds that she tends to bring in more of the voices of the "everyday woman" rather than famous or remarkable women because there are not many to choose from in her curriculum.

If there are any famous women I can talk about, I do. In Ancient China we talk about Mulan. In Ancient Egypt we talk about Cleopatra. I do bring them out 
[when I can], I do, but most of the time it is regular women like if you were in Egypt, where would you be?

When asked about the other ways in which she brings in women's history, Amy referred back to the textbook to see who was included. She pointed out a sidebar about Mary Magdalene in the chapter on Christianity, and talked about the lesson she did on comparing the real Mulan to the Disney version. Some of the methods that Amy described implementing included: leading discussions with her students, utilizing graphic organizers, employing the use of artifacts, reading in context, and comparing/contrasting time periods. However, she did emphasize that most of what she includes is out of the textbook.

Every chapter that we have, there is a section on women and children's role in society. They kind of have that covered whether I want to bring more to the table, I can, but this textbook kind of covers it.

This statement led me to believe that Amy's inclusion of women's history was based more on what the textbook included rather than her own desire to ensure her students were hearing women's stories in their history lessons. Moreover, if a different book had been adopted by the school district, it is likely that Amy's lessons would be based on that book, and if that book did not have a section about women, it is questionable whether or not Amy would indeed, "go above and beyond," to find materials on women's history to include.

Though Amy does believe that later in history, including women's perspectives is easier than including it in the ancient world. Additionally, she does feel that having more focus on women is better:

If there were people, then of course there were women. So [students] should know how far women have come in society; from where we were even 200 years 
ago, but [in this class] we're talking about thousands of years ago. They should know that [for women] it wasn't "all men are created equal" and [women didn't have] the pursuit of liberty and happiness from the beginning, that's changed.

For Amy, it is important for students to understand that roles for women have changed over time. She wants them to be aware of what their lives would have been like if they lived during a different era.

Though she is aware, and teaches about, how women's lives have improved, Amy does not consider herself a "liberal feminist;" and while she does believe that in most circumstances, women can do anything men can do, she also has beliefs to the contrary.

When it comes to job equality like in regular society, I feel like a woman can do anything a man can do; but if we were talking about military, no. There are some places, me personally, I feel that women don't belong and that's just because I've been there and I've seen it. I feel no woman should be there because there are some instances, and there's some things in war, where if it's just men dealing with men things and it's only with men that they become bonded with, they can be a little, to me, rougher. When you throw a female in the mix and something's going to happen to that female, then they get that protected. I just feel like there are some things that they will do to females that they wouldn't do to other males. That's just my own personal opinion. I feel like women don't belong in combat but some women would fight me on that. They'll be like "I can do anything that a man can do" but to me, what are you doing to the other men in the platoon? By being there and if something were to happen to you, whether you want it to happen or not, how are you affecting them? 
Amy beliefs about women in the military were striking. Like many of the participants, Amy had a hard time identifying as a feminist, even though she is pro-choice and believes women have the right to work, vote, and have personal freedom, she does draw the line at certain aspects of military service. She counts these among her political beliefs and was very adamant that she would never share such information with a class of students.

At the close of the interview, Amy noted that she believes she could do more to include women's voices. She said

I haven't really thought about it [including women's history] as much as I probably could have and this might be good for me because I can start looking. I know I do it, but maybe I can do it a little more.

Ultimately, the reasons Amy cited for her inclusion of women's history came down to what the textbook included and whose stories her students wanted to hear. 


\section{Classroom Observation}

Amy Wiggins's class was in a portable on the far end of the school campus. There was UCF memorabilia on the walls, some cheerleading pompoms, and a few inspirational posters on the walls. The class was made up of eleven male students and five females.

As students arrived, they saw on the board, the day's Learning Goal:

Students will understand what daily life was like for Romans and how they are similar and/or different than daily life today.

As the class began, students completed their bellwork (work done first thing when they arrive to the classroom) which was to define "gladiator." As they were working, the $7^{\text {th }}$ grade guidance counselor came in to talk to students about their elective course choices for the following year. One girl asked about Chorus, one boy asked about AVID, a program for college prep in middle school.

Once the guidance counselor left, sports theme music came on loud, and Ms. Wiggins addressed the class in a firm tone, "You know what to do, I should be seeing all books put up by now." Students got up from their desks and put their books away. Once all books were put away, Ms. Wiggins walked to the front of the room. In order to randomly select students to answer the bellwork discussion, Ms. Wiggins took the class roster, closed her eyes and pointed to a name.

Ms. Wiggins: [student's name] Tell me something about Rome.

Male Student: $\quad$ gladiators could be slaves

Ms. Wiggins: What is a gladiator?

Male student: $\quad$ a person who fought for public entertainment. 
Ms. Wiggins continued to call on students to give one fact about Rome; they get one point if they said a correct fact. Students gave facts about Caesar, Italy, peninsulas, Nero, and Punic Wars.

Ms. Wiggins: Today we are going to cover daily life in Rome. You are going to make a foldable. Find four facts about each topic: Homes, Gladiators, Women, and Religion. Use textbook pages 340-343 to find your facts.

Students got paper and began working. The majority of students were working independently. While students were creating their foldables, Ms. Wiggins circulated around the room helping students cut the paper and sharpened pencils. After nearly ten minutes, Ms. Wiggins told the students, "If you don't have your tabs cut and your labels written, then you are behind the curve."

One male student's behavior caught Ms. Wiggins's attention and she told him to go outside and yell and scream until he was ready to work. He came back in after about ten seconds and said he had cooled down.

While students were working, Ms. Wiggins played music from Spotify in the background. A variety of genres and artists were played including, country music, Lady Gaga's Paparazzi, and Tom Petty's American Girl.

Ms. Wiggins: FYI there is a really good picture of Roman homes on page 341. I don't want to hear that you couldn't find any facts about homes. I want to know how they are similar to today and how they are different from today. 
After about ten minutes of working, Ms. Wiggins addressed the class. "Tell me one fact about...

$\begin{array}{ll}\begin{array}{ll}\text { Homes } \\ \text { Gender of } \\ \text { student } \\ \text { (T=teacher) }\end{array} & \text { Response } \\ \text { M } & \text { Marble walls } \\ \text { M } & \text { Rain water collected in pools } \\ \text { M } & \text { Homes had bedrooms } \\ \text { M } & \text { They ate while laying on couches } \\ \text { F } & \text { Shops down the street }\end{array}$

\section{Gladiators}

$\begin{array}{ll}\begin{array}{ll}\text { Gender of } \\ \text { student } \\ \text { (T=teacher) }\end{array} & \text { Response } \\ \mathrm{M} & \text { Wore armor } \\ \mathrm{M} & \text { Fought to the death } \\ \mathrm{M} & \text { Fought animals } \\ \mathrm{T} & \text { Who were the gladiators? } \\ \mathrm{M} & \text { Slaves } \\ \mathrm{T} & \text { But who were they? } \\ \mathrm{M} & \text { Prisoners of war }\end{array}$

$\begin{array}{ll}\begin{array}{ll}\text { Women } \\ \text { Gender of }\end{array} & \text { Response } \\ \text { student } & \\ \text { (T=teacher) } & \\ \text { M } & \text { They clean and cook in the home } \\ \text { M } & \text { They got married at } 14 \text { years old } \\ \text { M } & \text { Not full citizens, they had few rights } \\ \text { T } & \text { Why did they get married at 14? } \\ \text { M } & \text { They didn't have rights } \\ \text { T } & \text { Y'all have had Sex Ed right? Because at that age they were able to have } \\ & \text { babies, that is why they got married then. } \\ \text { M } & \text { Tell me something else about women. } \\ & \text { They had to watch the house } \\ \text { Religion } & \\ \text { Gender of } & \text { Response } \\ \text { student } & \\ \text { (T=teacher) } & \\ \text { M } & \text { They believed in many gods } \\ \text { T } & \text { What's the word for that? } \\ \text { M } & \text { Polytheism }\end{array}$


Right. What else about religion?

M Different gods controlled different parts of life

$\mathrm{T} \quad$ Like Cupid was the god of what?

M Love

$\mathrm{T} \quad$ They took the Greek gods and gave them Roman names. Every Roman had an altar. That could be in Homes or Religion.

Ms. Wiggins: Alright, you have three minutes until we are going to talk about it. You should now be writing how they are similar and different from today.

Much of the student talk came from male students. In this first exchange, in which the teacher asked students to share their findings, only in the category of "Homes" did a single female student offer a response. This response was arguably gendered, as she talked about shopping being part of the Roman home. In no other category of responses did a female student attempt to answer the question.

After three minutes passed, Ms. Wiggins called for the students' attention again.

Ms. Wiggins: Who wants to tell me how homes were similar?

$\begin{array}{ll}\begin{array}{l}\text { Gender of } \\ \text { student } \\ \text { (T=teacher) }\end{array} & \text { Response } \\ \mathrm{M} & \text { Had roofs } \\ \mathrm{T} & \text { Different? } \\ \mathrm{F} & \text { We don't have shops at our houses } \\ \mathrm{T} & \text { But can we? How are they different? } \\ \mathrm{F} & \text { We don't eat on couches } \\ \mathrm{T} & \text { Good one, we don't. } \\ & \text { [the class disrupts here in a chorus of "We do!" } \\ \mathrm{T} & \text { We don't lay on couches to eat four course dinners. }\end{array}$


Ms. Wiggins: Who wants to tell me how gladiators were similar and different?

$\begin{array}{ll}\begin{array}{l}\text { Gender of } \\ \text { student } \\ \text { (T=teacher) }\end{array} & \text { Response } \\ \mathrm{M} & \text { We have armies } \\ \mathrm{M} & \text { We have sports } \\ \mathrm{T} & \text { Alright, different? } \\ \mathrm{M} & \text { We don't fight to the death } \\ \mathrm{T} & \begin{array}{l}\text { Right, we try not to kill anybody. Think about boxing, they fight, but not } \\ \text { to kill. }\end{array}\end{array}$

Ms. Wiggins: How are women similar and different?

$\begin{array}{ll}\begin{array}{l}\text { Gender of } \\ \text { student } \\ \text { (T=teacher) }\end{array} & \text { Response } \\ \mathrm{M} & \text { They clean and cook } \\ \mathrm{T} & \text { Still have babies and still raise children. What about differences? } \\ \mathrm{F} & \text { Can't get married at } 14 . \\ \mathrm{M} & \text { Can leave house whenever they want } \\ \mathrm{T} & \text { Yes, we can leave, we have rights, we are citizens, can make our own } \\ & \text { money. }\end{array}$

The bell then rang before the class could discuss religion. The students turned in their foldables, cleaned their areas, and left the room.

The second dialog between Ms. Wiggins and her class involved more female students.

When it came to houses and women, female students had more to add to the conversation.

However, there was no female involvement in the discussion on gladiators and Ms. Wiggins did not attempt to call on students who did not have their hands raised.

According to Tetreault's "Stages of Thinking about Women in History," Ms. Wiggins’s lesson fell under the category of Bi-focal history, in which the human experience is conceptualized primarily in dualist categories: male and female; private and public; agency and communion...efforts to include women 
lead to the insight that traditional content, structure, and methodology of the disciplines are more appropriate to the male experience. (Tetreault, 1986a) This lesson focused on ancient Roman life, and certainly contained a dualism between male and female spheres. Whereas the foldable sections Women and perhaps, Homes, could be considered under the female sphere, Religion and certainly Gladiators were under the male sphere. Ms. Wiggins address agency in her discussion of women, most significantly in her treatment of 14year-old wives and women's inability to leave home. 


\section{Aaron Branch}

Aaron Branch is a relatively new teacher at his school; this was his second year teaching Civics at a southeastern middle school. Aaron is a Caucasian male in his late-twenties who showed an interest in politics and science fiction. He grew up in northeastern New York and studied Southern history in college receiving a dual degree in Secondary Education /Social Sciences and History. I interviewed Aaron after school in the faculty workroom at his school. Like most participants, he believed this study would be focused on the inclusion of AfricanAmerican perspectives rather than women's perspectives.

At the beginning of the interview, I asked him to tell me how he approached the curriculum.

Well actually the lucky thing about teaching civics, especially what we go into, includes things like voting and the history of amendments, I actually get a lot of time to talk about multiple perspectives. I think you even sent an email asking me how many times do you include it? And I said usually once a week. I was lucky enough to go into voting recently and I talked about the use of poll tax in the south to deny African-American's equality to vote. I discussed the struggle it took for them to gain the right to vote through different amendments and things like that. So I plan when I see a lesson, I try to include from different perspectives other than just white males.

From this information, it is apparent that Aaron does make efforts to include multiple perspectives, especially when they align with content requirements such as voting and amendments. 
Once I debriefed Aaron on the actual purpose of the study he began to tell me about his past. When it came to his schooling he did not recall learning much about women in his history classes, even though he considers that he went to school during a progressive age when more and more perspectives were being included in the curriculum.

Throughout the time that I went to school, we were in a very progressive age, you know trying to include more of multiple perspectives in social studies, but sadly I was taught mostly by older white men who technically didn't include women very much. All I very much heard about was the presidents and things like that. So actually when I came in to civics, when I begin teaching, I want to make sure because of the high frequency [of girls in my class], not only the philosophical reasons why that's the right thing to do but also cause I have so many girls I teach. I teach a lot of girls. I want them to know that women have been a foundation for society. I even brought up the fact that recently, for example, that women really outvote men when it comes to participation in politics, that they're a big factor, a group that everybody wants to have participating. So I mean, traditionally, you think social studies like, you know with the guy, he's not going to teach women's history, but I try, I feel like we have to. And that's not bad, that's a good thing to do that. Because we're not in that world anymore where men are running everything. Women are going to college more than men, they're gaining higher paying jobs as well so we have to kind of inspire young girls to keep striving, to try to bring more equality because I don't think it's completely equal yet. I feel like if we keep, you know, teaching them of the past and the struggles that women went through, we can keep that going. 
Aaron was very aware of the exclusion of women from his own education. However, it did not appear as though that was the cause for his purposeful inclusion of women in his own lessons. Throughout our interview, Aaron emphasized his desire to foster equality in both his classroom, and the world at large. He explicitly discussed his attempts to make his student aware of the role women played in the development of the nation and the issues women face in contemporary society.

When asked how his past shaped his efforts to include more women's perspectives, Aaron credited his own teachers more than his family life.

It wasn't really from my family as much because I was raised in a very, just say, conservative household, so usually It wasn't encouraged to emphasize women, or anything else above anything. Not that that's bad, not like bad thing. Just, it wasn't as emphasized. I really learned it through, actually teachers more than anything. I had a lot of female teachers in language, arts and other [subjects]. Really in a way, they kind of influenced me to realize that women should be considered. Even at young age, I started to think about equality in every aspect of society. So, I mean, that was really what kind of defined my perspective on things.

Aaron did not feel that he was inspired by the women in his life to cultivate an attitude of inclusion. Moreover, he did not view his mother or the other women in his family as having a substantial influence on his beliefs about women's intellectual abilities. However, he did note that it was their hard work in their chosen fields that did give him some inspiration.

I mean my mother's wonderful. She was a housewife by the time I was born. For my older brothers and sisters, she was a hairdresser. She graduated high school 
but didn't go to college or anything like that. And mostly women in my life, personally growing up were like that. I'm from New York, a lot of [women] got into the stereotypes of like "hairdresser". My sister's was a hairdresser. My aunt worked for the transit system, things like that. So I really didn't have any women there but at the same time, they did kind of inspire me just how much they could handle really. People don't realize how much work that really is. So, I guess they did kind of inspire me in that way.

Aaron's feelings about his mother and the other females in his life were not initially positive when it came to how they influenced him educationally and professionally. It was in retrospect that he was able to draw a connection between their domestic efforts and labor in the pink-collar job market, to his own conclusions about the value of work, more specifically the value of women's work.

Aaron fostered a deeper awareness about the exclusion of women in history, when he was in college. He said that it all began with a report he wrote when he was 10 or 11 years old. The assignment was the write a report on a political figure and he chose Hillary Clinton when most of the other students choose the president Bill Clinton. He credited this assignment with setting the foundation for the non-exclusion of women in his own historical research. Aaron demonstrated a deeper understanding of women's perspectives when he discussed a college class on Southern History in which he gained an appreciation for the variety of women's experience when it came to race and social class.

Even though the emphasis was on the African-American experience, which was right to do that, and I bring that up too [in my classes], we also researched what it was like to be a woman, not just an African-American woman, a white woman 
as well, and just being put in the position you're put in, how you're kind of viewed in society. So, I mean, that also peaked my interest too, and it's kind of the forgotten voices of history, you know. If we only study the big names, we don't think about everybody else who's a part of it.

This class seemed to be a turning point for Aaron. It was here that he began to view women's experiences as more than one-dimensional. It is also where he developed a desire to learn more about the voices of people not usually included in the historical canon.

I mean, the voiceless have taught us more about history than the big names ever taught us. And, that's why I feel it's good to focus on the people who usually were not emphasized in all of these for decades in society. I mean, we didn't even research what women were like in the revolutionary war, because all we cared about was Benjamin Franklin, luckily the 60s, the progressive era of history, historians really changed that.

His awareness of the exclusion of women from history extended to the information included in history textbooks and what is traditionally covered in history classes.

It's like women... when you read a history book, especially then, it's like women didn't really exist, until they talked a little bit about Harriet Tubman, and then they disappeared again until the struggle of the 19th amendment happens. And, then they disappeared after that too. Women, to me, were always kind of forgotten whenever I read history. I usually looked them up on my own. Especially with the invention of the internet, it made it possible. I got to look up other women who came into the picture and yet, I still wish I knew more, because I feel... I'm still a novice in understanding about women, like specific figures, 
especially. But, you know you'll learn about the usual like Susan B. Anthony, you know, Elizabeth Stanton, you'll learn about all of them. But not as much as you'd... that should be, honestly or I thought was necessary.

Aaron's notion of the exclusion of women from the history curriculum somewhat aligns with Sadker's (2009) description of the time periods that are inclusive of women's history. As a teacher, Aaron's goal is to find ways for his students to relate to the content he presents. I want [to change] the whole perspective of [history as] what they always call "March of the Dead White Men". To me that's not... they can't relate to that. I'm not going to say I'm going to ignore George Washington but, we have to include other perspectives...

Additionally, Aaron drew a connection between his political beliefs and his efforts to include multiple perspectives in his class.

The reason why I'm in the political perspective I am [Democrat] is because they celebrate the diversity and multiple perspectives in life. That's why I'm a part of it and why I'm so connected to it.... and as political organization [democrats] are the best at kind of encouraging us to have progressive ideas about the new world we're forging.

When asked about the resources he uses to teach about women's history/perspectives, Aaron discussed a lesson he teaches on the Equal Rights Amendment (ERA). ...talking about how the Equal Rights Amendment has really been struck town multiple times. And saying, what this is about? Like, who's this for? ... [the] ERA especially, it's something that important. I never learned about it in school. I didn't even know it existed. I guess maybe because it's such a lightning rod 
issue. You know, back then people are all afraid to bring it up. I really want to encourage them [the students] to understand what it was all about. And they did, they really did.

For this lesson, he had student read an article from 2000 that included both sides of the argument surrounding the ERA. He used the article as a reading activity and had the students describe the ERA, why it hadn't been passed and why a struggle existed. However, he did not get the students to think critically about the information and come to any conclusions about their own perspectives relating to the proposed amendment. During the interview, Aaron said that if he were to do the lesson again, he would have students take a stance on one side or the other. Later in our conversation, Aaron discussed how his inclusion of women's voices affects his students.

Whenever I do mention anything with women's history, they'll [the girls in class] perk up a little bit. I know they do that. So I mostly feel like they're afraid [to show interest] because of the boys in the class, because I always see the boys go roll the eyes, that type of thing. And I'm trying to get, that condition out of them. I understand that they're twelve-year olds, but the thing is, I'm kind of scared, number one that they even have this perspective in the first place, wondering where they're getting this. It's like "Whoa! Women's rights? Women's history?" And two, I feel like, the girls are sometimes afraid because that's what society expects of them. They expect them to be, kind of like, you know, some girls will act like they're not intelligent, and I'll get work from them, and it's amazing. And it's well written. And I try to talk to them about why they don't, you know, do that more. They never gave me a straight answer. I feel like its pressure from the 
boys as a whole where it's like... there are different stages and the boys are still immature, they see that. But at the same time, they kind of don't want to, I don't know, maybe they don't want to be like the smart one, you know that stick out. They kind of just want to be accepted by everybody else. They're not at that stage where they're comfortable. I have plenty of girls who are far and above all the rest of my students. I'm not saying that they're all like this but, it's a handful that is still afraid to kind of let their voice be heard. I've been trying to understand why that is.

Here, Aaron showed both his hopes for his female students and his concerns about perpetuating the marginalization of females. He points to the microcosm of society in which his student inhabit where the girls supplant their own intelligence to fulfill a gender norm expressed at the middle school level. It was interesting to hear Aaron discuss this observation since I experienced this phenomenon in my own junior high school years (as mentioned the positionality statement in chapter 3).

In response to how he determines which women's issues to include in his class, Aaron says that he will discuss any issue in class that is relevant to society.

Of course, there are some issues like abortion that they [school officials] don't really want emphasized as much. I mean, I have mentioned it before, you know, I've talked about why it's such a controversial issue. But we haven't gotten in depth. But if it comes up in class, we talk about it. I told them that my perspective is, if it comes up in class and it's relevant to society and what we're teaching about, we going to talk about it. So I've had kids ask, you know, "what is abortion?" I have to explain to them in layman's terms what it is. And I've had 
the question of why are women so defensive of it. I'm like, we'll its women's health. A lot of women feel like it's their private... that it's their bodies. I have to say," some women" feel.

Aaron is very aware of the controversial nature surrounding so many issues relating to women's history. For him, that is the most difficult aspect of incorporating women's perspectives. Another area that proves challenging for him is finding resources, especially because as he mentions, a lack of inclusion in the textbook. The way he navigates this obstacle is to take extra care in order for his students to hear stories beyond the traditional canon even though he believes there is not room within the scope and sequence outlined by the state and county to do so. I do it anyway because I personally, feel like I have to. Not that they tell me that I have to do, but what I feel that I have to do. You know, I don't care if it says "you don't have to talk about this part of the history". I'm going to talk about it anyway because to me it's not right to leave it out. So no, traditionally, the curriculum's not there but I make it work. I fit it in.

What Aaron says here is the central focus of this research. In understanding why some teachers go above and beyond to include women's voices, for Aaron, that reason boils down to his own principles.

The reason that I do it, personally, is number one, it's the right thing to do. I just feel that we should include all perspectives, because sometimes we teach from such a one-way perspective that we lose significant groups of people in our study. It's no doubt that when you walk into any [event] with history or social studies [professionals] and you look around the room, and you know the majority of what you're going to see are men. White men. You're not going to see as many 
African-Americans. And you're not going to see women. And that's not because they don't have any interest in history, it's because we never gave them to anything to be interested in. I'm not saying they don't find Thomas Jefferson fascinating because we all do, but if all you're hearing about every single day is that over and over again. How can you feel connected when it's like women never made history? So I mean women do make history. And the thing is, sometimes they just don't make it in textbooks. We say, what is [that saying], "Well-behaved women never make the textbooks." I always like that one.

Aaron elaborated on why he believes women are so marginalized in history:

What is the danger, what is the problem with talking about women's history? Why are we so afraid of it? It's like you hear the slang remarks like, "she's a femi-nazi" or something like that. Why are we so scared? And to me fear is... prejudice comes from fear, that they're scared. They're scared about losing their grip on what social studies is.

He believes that as a society, we are actively working to leave women and minorities out of history. He supposes veteran teachers do not want to undertake adding multiple perspectives to their lessons because it challenges what they have been doing throughout their careers.

It's them [veteran teachers], kind of admitting they've been wrong this whole time, because they haven't taught it. That's where I think, with the teaching side of it, why we get such opposition. [Veteran teachers] don't want to admit that maybe they did something unethical in a way, by not including an important group in history. 
It is apparent that Aaron wants to see changes in the curriculum to include more women's perspectives, history, and voices. He was also one of two participants who, without qualification or exception, considered themselves "feminist."

I remember when Phil Donahue said "I'm a male feminist." And I'm like yeah, I'm the same way. I am a feminist. I think that women shouldn't be left out of anything a man can do. I think when they were talking about fighting in the military, I was for it. To me, I don't understand why they should not be able to. I mean that's the thing. To me, it's just, I guess I would be called a feminist, and I've just always been one in my mind. It's just to me that it has always made sense that everybody gets the same opportunity. Everyone, if they have the same skills, should be able to do the same thing. So yeah, I'm definitely a feminist.

Considering the backlash against feminism in the United States, and that many people believe we live in a post-feminist world in which "women's current status is okay. [And] who are unaware of discrimination and who are more likely to see the battle for equality as a past victory rather than an on-going struggle" (Buschman \& Lenart, 1996), it is remarkable that Aaron so unabashedly takes on the label.

Aaron believes that students want to learn about those who history has been left out of the narrative. He knows that his interest in society filters down to his students and when he explains things to them, they get as upset as he does. He points out to them how far humanity has progressed, and tells them that their generation is going to continue make things better for those who come later. 


\section{Classroom Observation}

As I arrived at Aaron Branch's classroom I found a seat in the back of the room.

Students were finishing their bellwork: "What do you think the ERA is?" This was a seventh grade civics class, a new edition to the Florida curriculum, and one that has an End-of-Course

Exam. There were 7 male students and 16 female students in the class. After a few minutes of students writing their predictions, Mr. Branch asked the question verbally and began writing the students' predictions on the board. Students responded with guesses pertaining to race, gender and civil rights overall. Mr. Branch asked students about the civil rights amendments and as a class they were able to remember the $13^{\text {th, }} 14^{\text {th }}$, and $15^{\text {th }}$ Amendments.

After a brief discussion, Mr. Branch introduced a video entitled The Equal Rights Amendment: Unfinished Business for the Constitution, a 17-minute documentary that "traces the expansion of women's rights in the United States from the writing of the Constitution to the 72 year struggle for woman suffrage to the ongoing campaign for the ERA" (Francis, 1999).

As students watched the documentary, each demonstrated engagement in the video, none were sleeping or off-task. Mr. Branch circulated the room during viewing.

The documentary gave a brief history of feminism, from the Seneca Falls convention to the work of ERA activists through the 1980's to present day. It centered around the challenges faced by women to gain the right to vote and have discrimination based on sex eradicated constitutionally. The video correlates to the Bifocal stage of Tetreault's "Stages of Thinking about Women in History," because its focus was on women's oppression and misogyny; and, women's efforts to overcome that oppression were presented (Tetreault, 1986a). 
After the video, Mr. Branch asked when was the $19^{\text {th }}$ amendment passed? Students responded 1920; he followed-up by asking "When was the ERA started?" After a few responses from students it was determined that the ERA was started one year later.

Mr. Branch: So who does the ERA cover?

Student: women

Next, Mr. Branch passed out an article Equal Rights issue raised once again from Floridatoday.com April 22, 2013, (Schreiner, 2013). He introduced the article by pointing out that it was a secondary source, and a trusted source due to the fact that it was a newspaper article by an Associated Press journalist. The article discussed how women's rights activists in Florida were continually attempting to get the state legislature to vote on the ERA.

As the class read the article aloud, Mr. Branch stopped at various points, both asking questions of the reading and pointing out important information for students to highlight.

Student: If the ERA never passed how come women are able to vote?

Mr. Branch: Good questions. Is the ERA and the $19^{\text {th }}$ amendment the same?

Class: $\quad$ No

Mr. Branch: No, the $19^{\text {th }}$ amendment gave women the right to vote, but not all equal rights.

Mr. Branch then outlined the proposal and ratification process for amendments, and the different types of amendments. Active reading continued as student highlighted important information. As the reading continued, Mr. Branch pointed out that no one was speaking out against the ERA, but that the Republican Party was not for the ERA. He instructed them to 
highlight "equality for men and women." He then pointed out the language of the amendment and asked students what it meant.

Throughout the lesson Mr. Branch called on one male student repeatedly even when there are other students, both male and female, raising their hands. Considering the fact that twothirds of the class are female, this is noteworthy. Although there are a number of reasons why this could have been the case, perhaps because he was being observed, he called on a student who he knew would know the correct answer, or perhaps he was unaware of the teacher-student dynamic between the rest of the class and himself.

Below is the dialog from the class discussion following the article.

Student: But doesn't women already have equal rights?

Mr. Branch: I don't know. Do they? We're gonna talk about that later.

What questions does the article not answer?

Students: What isn't equal?

Has the ERA been passed?

Are people affected?

Do women have equal rights?

Mr. Branch: What issues come up with women's rights?

Students: discrimination

Combat

Workplace

Sports

Politics

Pay 
Mr. Branch: Why can't women fight in military?

Students: They're not strong enough

Not smart enough

Men afraid to hit a girl

If women are really better, they'll be pushed down

Girls are too emotional

Student: $\quad$ Why hasn't it been passed?

Student (f): Maybe because people don't want to change

Student (f): Fear of change?

Mr. Branch: Is fear based on logic?

Class: $\quad$ No

Mr. Branch: What is society always afraid of?

Women having power.

Do women have equal rights?

Student (m): Yes, they can work the same jobs, and do the same stuff

Student (f): No, they are always discriminated against, "She's just a girl" (whiney voice).

Student (f): Girls can't win a fight because guy will feel stupid if he loses, then he'll say he let her win.

The discussion did not have a neat conclusion, as the bell rang before the dialog had ended.

During this discussion there was an obvious focus on physical power, even on beating up

someone. Unfortunately, this was not addressed, either due to lack of time, or perhaps it was not apparent to Mr. Branch and therefore, to him, required no further comment. 
During the interview, Mr. Branch said that if he were to do the ERA lesson again, he would have students take a stance on one side or the other. However, the lesson he presented for the observation was quite similar to the one he described in the interview and yet he did not ask students to decide for themselves which side they would support. This could have been due to time constraints as well, nevertheless, opportunity was not provided for students to engage critically with the information.

Overall, Mr. Branch's lesson fell into the Bifocal stage of Tetreault's "Stages of Thinking about Women in History." As with the documentary he showed in class, the rest of the lesson also centered its focus on women's oppression and misogyny and, women's efforts to overcome that oppression (Tetreault, 1986a). Since the lesson observation was planned, Mr. Branch was able to teach a lesson that he knew would fulfill the goals of this research. However, it is not clear how he incorporates women's perspective on a weekly basis when the content is not focused explicitly on the female experience. 


\section{Mark Webb}

Mark Webb teaches Advanced Placement Psychology and one class of accelerated, college bound, ninth graders. I interviewed him in his classroom during his lunch and planning time, which ran together. Mark is a Caucasian male in his late thirties. For Mark, teaching is a second career. He received his master's degree in social science education after working in the mental health sector for over a decade. He grew up with a stay-at-home mother and a military father; he considers himself a "very accepting and tolerant person" to which he credits the diversity of his military upbringing.

When asked about his past, and how it might have impacted his inclusion of women's perspectives on a regular basis, Mark believes that growing up with a chauvinistic father made him more aware of society's treatment of women.

I'm trying to think of when my tolerance and my acceptance was at a heightened point growing up because obviously, I learned my philosophy throughout my childhood and I don't know where that would have came from. Maybe it's because my father was very chauvinistic and that always bothered me, so that could be why. I don't want to put a point of emphasis on that as "why" but I know he was very chauvinist growing up, but I'm sure that's because of his military background and the time. So maybe, me not liking that part of his personality kind of made me more tolerant and more understanding of those rules.

Though Mark said he did not want to emphasize his father's chauvinism, it did leave a lasting impression that affected his future behavior. In addition to his parents' filling traditional gender 
roles, Mark also indicated that being a male in a female-dominated field also impacted his views and behavior related to including women's perspectives in his classes.

Well, I was an education major, and being an education major, I mean, if you're a male, you're a minority. And so being almost in a flipped role from our society, being a male in a very much female-dominated profession has opened my eyes to those kind of situations, maybe to be more, at least vigilant and understanding to include all different kinds of aspects and more specifically women's roles... So, to me, I guess, trying to, when I look back at how I grew up and how I started to think of tolerance when it came to things like that, rights and women's roles, I guess that's where... I guess it kind of started with my father, this taste for his kind of behavior toward that and then being in a situation in college where I was pretty much around women all the time.

Mark was unique in his assessment of his own minority status as a male teacher and how that impacted his views on the treatment of minorities in social studies education. No other participant drew that connection. He also commented on his minority status as a male among females in his work environment, in his favorite class (journalism) in high school, in his past career as a mental health worker, and in his own psychology classes which are populated predominantly by female students. However, he did acknowledge that the field of social studies was one area that was indeed dominated by males.

In discussing his own education, Mark mentioned the influence of one important teacher who he categorized as a "women's rights activist."

I remember I had a teacher named Mrs. Wiffle and she was definitely a woman's rights activist because I can remember conversations and she just exuded that in 
[class].I remember her being very forceful and prominent with it in class, probably inappropriately so actually now that I think about it. But she was definitely more in your face about what women can do, the power of women and things like that.

Mark went on to describe how much he liked this teacher and the impact she had on his life. He talked about her being a "strong woman" and that he always liked to be around strong women, especially after the death of his mother.

Oh, I liked her. She was a strong... I really liked her. I mean that's why I stayed with journalism for a long period of time. Yeah, I really liked her. I've always, for some reason, psychologically it could be my mom died when I was 18 so I think for that reason, I've always resonated with strong women, intelligent women, strong women, that's why I married one.

Having "strong women" in his life was clearly important to Mark. Essentially, his affinity for this type of female had, in some ways, played a role in Mark's conscious incorporation of women into his content.

Additionally, Mark showed a distinct awareness of the exclusion of women's history/perspectives from the social studies curriculum. From his own schooling for which he noted "the glazing over of women and their significance" to the content in the classes he teaches now:

In my subject alone there are many different aspects of the inclusion of women or actually more specifically I would say the exclusion of women, especially when we start talking about historical figures because most of our historical figures...there's many tie-ins to female roles in the history of psychology that are 
almost like sub context and not mentioned as much along with the major figures in psychological history.

This omission of women's contributions to the field was what Mark illustrated to his students for his observed lesson.

In our discussion about the social studies curriculum, Mark indicated that he had always noticed the homogenous nature of the content. In his own schooling, he remembers learning about Amelia Earhart and Sally Ride, but in a "forced kind of way, not an inclusive kind of way."

It has always irritated me, the things that have been excluded but that's my political beliefs and all that kind of stuff that follows along with that. But yeah, I've always been irritated by the lack of diversity and curriculum.

When it came to his own pedagogical practices, Mark described how he brought in women's perspectives and the effort it took to bring in such content.

Because I have to incorporate history into psychology and our nation's history is that women's rights were not granted until later on; and we didn't have tolerance toward those kinds of things, we didn't accept it and properly encourage it. So when I teach history, I always find myself apologizing for [the lack of women]. So it's harder to find older information, like Anna Freud, I go into that...but it's difficult to find older stuff when it comes to psychology about women.

Mark was cognizant of the challenges he faced when trying to incorporate women into his lessons. In addition to the challenge of finding information about women to integrate, he also felt difficulty garnering buy-in on this topic from male students. 
It's tough to get my male students to buy into it also I think too. I don't think they really know and I don't think most 16 year olds, 17-year-old kids know anyway what you're actually trying to do. How tolerant you are or how diverse you are in your teaching, they just have blinders on at psychology. I would hope they would know later on and like, "Wow, Mr. Webb was pretty open-minded about things. It's amazing what we talk about in class." Because psychology involves every gamete of science. So we will talk about sexual activity, sexual behavior, and we talk about you know, responses of men and females. And I don't think kids are ready for that when they get into this class, like "wow. We're talking about a female orgasm. It's amazing." And it's like "wow. I can't believe we're talking about this." I'm sure 20 years ago. We wouldn't be able to do that in a psychology class. So, maybe that's good; I think the women in class really appreciate the openness we have toward women's issues and all that kind of stuff in class.

Despite the fact that Mark has obstacles to his inclusion of women's history, he finds that he is able to discuss women's issues, such as female sexuality and representation within the content, with more ease. He does so also because so many of his students are young women.

It's easy to teach what I teach and incorporate women's roles and things because I have so many female students. I think it would be more difficult if I had more male students. I don't think I would get buy-in from the male students as much. It's easier with the female students. 
When it came to Mark's feeling about teaching male and female students, he was very clear about his preference for teaching and coaching females. This was very reflective of his opinions about gender roles, and overall generalizations about female vs. male behavior.

If I had a choice to coach a male team or a female team, I would always coach a female team and the reason being is that, I always think females buy into the idea of "team" much more than males do. I think males are more independently involved than they are with the collective group process. I've always thought that females are more in-tuned to be accepting of the information than men are overall. And I think that comes from my own brain too. I know how I was growing up with coaches and things like that. And I might listen but I wasn't really listening. So I think in my own life, when I'm coaching females, I always seem to have a better relationship with females, younger females, my best students typically are bright young females and I don't know why. I'm not sure exactly what that is but I've always been more comfortable teaching females. I really don't like coaching boys ever. I really don't. I've done it before and it's such a pain. It really is. They're so egotistical too like... there's a joke out there that if you say something like, "man, we got to get out there and we got to do this, we got to do this, we got to do this." and then if you're coaching boys, they're all sitting in there going, "he's not talking to me." You know? He must be talking to somebody else. And if you're saying that to girls, all the girls are like, "he's only talking to me." You know that kind of mentality? I think girls take in and I actually think girls accept feedback so much better than boys. 
Although Mark was generally discussing coaching here, it is significant due to the fact that his preference for teaching and coaching females could have a major impact on his motivation for including women's perspectives in the classroom. Since most of his students are female, he has a distinct interest in providing content that is relevant to them. In fact, to Mark, the single most important factor when determining his content choices boils down to relevance.

When I first started teaching it was all about the information. It was just, get them the information. But then, once I started realizing that it's not good for me to do that, and it's not good for them, for me to do that. Then I started realizing the [importance of] relevance, like how to make it relevant and I think once I started doing that and realizing that once I would do a focus on females, or explain things from a female's perspective, or talk about an issue that a female would never be able to talk about in other classes, that they could be open and it was easy to do that in my class because of the subject. I started realizing the power of using that in class. Now, I educate female students but I educate both male and females students when it comes to that. I don't know when that changed but it definitely changed in the last five years. I'm definitely more cognizant of using that approach and making sure I use that approach in everything that we discuss somewhere, somehow.

Mark explained that "relevance" meant students were able to use the information in their own lives. He noted that when he deviates from ensuring the content is relevant to his students, they see it as "something to memorize" or as just "notes on the board;" however, when he concentrates his efforts to promote applicable content then he feels the students take in the information more thoroughly and find it more interesting. 
Mark uses a variety of resources to incorporate women's perspectives. First, he attempts to use the most current research available. He does this because the most current psychological research is also the most gender balanced. He also subscribes to a number of journals, utilizes web resources, and purposefully includes readings by female authors and researchers. For instance, Mark assigned his class a book analysis for which they were to read one of 14 approved psychology books (non-fiction, non-academic), and produce a critical analysis of their choice. Of the 14 books, five were written by females.

If I'm teaching mostly females and giving them all male-dominated curriculum, it's going to tune them out. Where they can feel enabled more often than not is when I give them a female author or a female researcher or part of our reading assignment. We have a reading assignment for a project, novel based project for psychology. And I specifically included 5 on there from 5 women, one of them being Odd Girl Out [by Rachel Simmons]. I mean, the girls that read that book are just so enthralled with it. I get more reaction from girls reading that book than I ever have guys reading any book ever. It's about the under culture of women's violence and the girls just, they eat it up. When I read that book, I was shocked and it's a very eye-opening book. It seems like ladies this age, 16 or 17 years old, when they start to read that book, they really feel empowered by the idea because I watch boxing on TV, they'll watch wrestling and they'll watch all of these stuff MMA and all that kinds. It's almost always, it's a male thing, accepted thing and males can fight at schools. If females fight schools, it's all like, oh my god, what's wrong with them? Why are female... "Ohh look at female body builders, it's disgusting." And it's just what culture tells us about it but the 
undercurrent of women's violence in America really opens their eyes and it allows them to say that it's okay for them to be angry and want to beat someone up, you know, inside of their own brain. It's alright to feel that way. It's perfectly fine and they go through stories and it's a very good book and the girls typically enjoy that read. (Simmons, 2003).

It is worth noting that Mark draws his students' attention to the gender norms associated with violence. Unfortunately, this is not a book he requires for all his students, only those who chose to read it for this particular project. In the future, however, Mark said that he would like to make Odd Girl Out, or another similar book, required reading for all of his students.

I think a big challenge would be to get a really good piece of female psychological literature that we can all read together. I don't like to push things on my students but I do see the value in students, especially male students, reading about women's roles in history or women's roles in anything. The way [Odd Girl Out] drew a response from the females it almost makes me want to make it a mandatory thing for all my students to read next year. Then, I would really have the buy-in and then I can really feel good about including that stuff because then I know that it's not just I'm trying to appease the female students. I know I'm actually just appeasing my students as a whole because it really shouldn't be... it should be an act to process that is... you should not have to be cognizant about it. And I know that's the ultimate goal. It's that, you just do it because you do it. You include different diversity, you include different gender, and you'd include that because it's what you do. It's just part of your habit, part of your system. So that's how I proceed until it's part of my everyday thought and 
making sure without having to really make sure. That's when I know it's been successful.

The process of thinking about his motivation for including women's perspectives and the methods he utilizes in order to do so, provided Mark time to reflect on his teaching practice. Perhaps he would not have considered making a book about female psychological issues required reading for the entirety of his class had it not been for discussing plans for including women's perspectives in the future.

Beyond the explicit curriculum, Mark acknowledges the impact teachers can have on their students through the hidden curriculum, specifically when it comes to issues of gender equity.

[To me] there is no different between the genders. If anything, females are more tolerant, more open-minded. My overall approach personally is, I just don't like ignorance. I don't like it as a teacher. You wouldn't stand for a kid not knowing what two plus two is, or as a teacher, how could you stand for a kid not understanding what equity intolerance is? So, that's my personal stance and when I see things that don't fly with that, I get involved, I try to. So, as an educator, through hidden curriculum, I can do that and feel good about it; but then at the same time, I know other teachers, through hidden curriculum, are working the opposing the point and [there are others] probably still afraid to introduce that kind of stuff or not wanting to. So, the school system is a microcosm of like different worlds.

Based on the information given through this interview, Mark works to include women's perspectives into his class, both through the explicit and hidden curriculum, thus he has, in some 
respects, seemingly achieved a level of inclusion in line with Tetreault's "Multi-Focal, Relational History" stage. This stage is defined by providing a "gender-balanced perspective, which serves to fuse women's and men's experiences into a holistic view of human experience." (Tetreault, 1986a). However, beliefs and classroom practices are not always in perfect harmony. 


\section{Classroom Observation}

Mark Webb's AP Psychology classroom was relatively quiet as I entered ten minutes before the end of class. The walls were decorated with student-made collages based on who they thought they were. There was a plethora of UCF memorabilia decorating Mr. Webb's desk area. Live plants and a Democrat Donkey stuffed toy laid upon the shelf near his work area. The cabinets were decorated with Rorschach inkblots and there was a quote of the day on the board that read:

"Egotism is the anesthetic that dulls the pain of stupidity." - Frank Leahy

In a class of 30 students, there were 23 girls, six boys, one student whose gender was unidentifiable. Students were gathered in groups of four conversing with one another while looking through piles of books upon their desks. Prior to my visit, Mr. Webb told me that students would be engaging in an Advanced Placement (AP) test review. As I settled in, students continued working, asking Mr. Webb questions about the material; he answered them and provided more information as to what he is looking for in an answer. The bell rang and students left in an orderly fashion.

As the next period began, students arrived over a period of about five minutes. Mr. Webb addressed a female student, "You look brighter today. I see you are wearing white, rather than always dark colors." Other bits of small talk ensued, while Mr. Webb stood at his desk welcoming students into the room.

The bell rang and Mr. Webb said, "Get out a full sheet of paper please." Students did so but before beginning the quiz, Mr. Webb introduced me to the class, telling them that I was there to observe him, not them. He noted the type of observation I am engaged in was not 
"naturalistic," and asked students what made it so. One student raised her hand and said that it's not naturalistic because Mr. Webb knows I am there observing him. After praising the student for getting the right answer, he asked students to choose a color, they/he picked yellow, and he began administering a quiz in which he orally asked questions and students wrote their answers on their paper.

The questions include information on brain structure and daily biorhythms.

During the quiz, Mr. Webb redirected side conversations and throughout the quiz remained standing in the same place. Once the initial phase of the quiz was finished, students asked for certain questions that they missed to be repeated. Mr. Webb repeated the questions as many times as students asked, even if other students had asked about them. After all questions have been addressed, Mr. Webb instructed students to switch papers with a neighbor to quick grade the quiz. Students were to write their own name at the bottom of the paper that they were grading. During grading students answered each quiz question verbally. For one particularly difficult question, Mr. Webb said "Alright, someone who is a smarty-pants answer the next question." He then called on a female student, who did get the question correct. Mr. Webb continued to call on students, one female student complained that he did not know her name; however, he did call every other student's name correctly throughout the Q\&A session.

After the quiz grading, the lesson moves on to a discussion about the books students have chosen for their individual reports.

Female student: $\quad$ My book is boring.

Mr. Webb: $\quad$ What book

Female student 1: The Man Who Mistook His Wife for a Hat 
Mr. Webb: Books aren't like movies. If you go to the movies, you stay for the whole thing, but with books, you can switch any time you want.

Female student 2: I really like Odd Girl Out

Mr. Webb: Can you tell us what it is about?

Female Student 2: It's about aggressive girls

Mr. Webb: What is it about aggressive girls that make us uncomfortable?

Male student: $\quad$ Because we don't like hearing about girls and aggression, it is against gender roles.

Mr. Webb: I really like that book for boys to read. It's a different perspective for us.

Twenty-three minutes into class, Mr. Webb told students to get in groups of four to complete a scavenger hunt for AP test questions. He turned the lesson into a game that was to occur over multiple days; whoever achieved the highest score would win a prize. As students moved into groups Mr. Webb was circulating, returning papers. Question four of the scavenger hunt read, "List three women in psychology and list their contributions?" This was the only specific mention of women's history or women's perspectives on the scavenger hunt activity. From across the room I heard a male student say, "There are no girls here!"

As students continued to work in groups, Mr. Webb went around answering individual questions. One student asked about the limbic system, to which Mr. Webb asks, "Why do we like dogs and not snakes? It's because dogs can give affection and show emotion. Snakes cannot. They don't have a limbic system."

Another student asked about the female psychologists (question four). Mr. Webb walked over to that group of students to assist with their query. 
Mr. Webb: Where can you find women psychologists? Are there any that pop into your head?

No student responds.

Mr. Webb: If I say 'parenting styles' what would you say? What about attachment styles?

Some students mumble possible answers.

Mr. Webb: $\quad$ So we know their theories but we may not know that they were made by women.

Let me address number four to the class.

How many of you could think of three women right off the bat?

No student answers yes.

Mr. Webb: $\quad$ The idea is, if I asked you to think of men, you'd be able to no problem. Class verbally agrees, choral response, "easy"

Mr. Webb: Why is it hard to think of women?

Student: $\quad$ We don't see women as psychologists because we don't think of them. It's against gender roles.

Mr. Webb: One student last class said 'because they were as successful' and that just turns my stomach. They were, but weren't given the same chances. You remember Mary Calkins. She went to Harvard but wasn't allowed to graduate with a $\mathrm{PhD}$ even though she did all the same work as her male counterparts. 
During this conversation, Mr. Webb clearly addressed gender and pointed out institutionalized sexism and, in an accessible way, the students' own prejudice. He did not say, "That's sexist" but allowed them discover themselves, how their own prejudice had stopped them from knowing the answer to that question.

Following the class dialog, Mr. Webb listed some other female psychologist for the students to look for. The class continued with students working in groups and Mr. Webb circulating to answer questions. At the end of class, Mr. Webb asked students to put away their books and realign the desks.

This lesson, though not specifically related to the inclusion of women's history/perspectives, illustrated how Mr. Webb incorporated women into his everyday lessons. Whereas some participants taught lessons that would specifically meet the needs of this study, Mr. Webb proceeded with his regular class plan and allowed me to see how he would authentically address issues pertaining to gender in his classroom.

Although during our interview Mr. Webb appeared to encapsulate the highest level of including women's history, this lesson in particular did not actually rate as high on the scale. The nature of inclusion, particularly during the scavenger hunt, was limited to identifying women who had been traditionally left out of the Psychology canon. The concept behind question four was for students to identify the "missing women" from history. In this case, Mr. Webb's lesson was at the second stage of Tetreault's "Stages of Thinking about Women in History", the Compensatory History stage, which is defined here: "The absence of women is noted. There is a search for missing women according to a male norm of greatness, excellence of humanness. Women are added into the traditional structure of the discipline but the structure and methodology are not challenged" (Tetreault, 1986a). Thus, Mr. Webb's lesson called 
attention to the lack of representation of women within the context of the course; moreover, once the missing women were located, they were inserted into the traditional structure with only slight questioning of the structure that originally caused their omission. 


\section{Ned Hudson}

Ned Hudson is a gregarious Caucasian man in his mid-forties. He teaches six periods of $11^{\text {th }}$ grade American history in a predominantly Hispanic school. Ned has been a teacher for approximately ten years; and received his master's degree in Social Science Education. Ned grew up in a military family, and thus moved many times and did not have one particular place in which he grew up. In our interview, Ned discussed how he interweaves women throughout the content he teaches. Much of what he discussed related to the various women whose stories he is able to include in his lessons.

As we started the interview, Ned, like each participant, was under the impression the study was regarding the inclusion "multiple perspectives", not specifically "women's perspectives." Interestingly, he was the only participant who, prior to being debriefed about the actual purpose of the study, discussed how in integrated women into the curriculum.

I integrate women, I've always integrated women. I always make sure we play "I am woman" and we do the ERA and we do the movement in the 70s' because that is when I grew up. So I am familiar with those types of things. That sort of diversity speaks to the fun element because you are inclusive of all groups, even the gay and lesbians. I make sure I show Barbara Jordan. And there is little clip about that she was a gay-- a lesbian woman. And I show who she is, what she represents. We look at her in Watergate, with that diatribe she puts out and then we say "Oh you know, by the way, just so you know, she's gay.” No big deal, but those types of things. And that seems to work and resonate well with the students. So, in integrating the diversity it actually works well in the lesson planning for these kids because they're all diverse, a pretty diverse group. 
Ned was very clear that he made strong efforts to include a variety of perspectives. He believes that creating an inclusive environment is critical for his students who thrive in situations where they hear stories outside of the traditional canon. Ned was also the only participant who intentionally included perspectives of LGBT women in such a manner that the stories of women who were included in his lessons illustrated the variety of women's experience. Thus, Ned's lesson took a more holistic approach to inclusion, rather than focusing merely on the story of middle class or elite white women, or those women who achieved a "first" in a conventionally male dominated field, Ned discussed women who lived outside of mainstream gender norms.

Once Ned was aware of the actual purpose of this study, he described how he incorporates women's history throughout each of the units in the curriculum. Despite the fact that he believes diversity of experiences should exist throughout the course, Ned indicated that he was not able to include women's perspectives until the Civil War.

When we get to the Civil War, I begin integrating female participation because war-- and then of course I'll be able to touch back to the world history and say "In war, women are the ones that really get hosed, because they pick up the slack while the boys go play war games. And we talk about the beginnings of the Red Cross, the Clara Bartons of the time, and I say "Now we are going to lose [women] for a while..." because I have to go through the Industrialization period where we are talking about the Barons of industry, not the Duchesses. But, I do pick them up, obviously during the Progressive Era because we've got to talk about the Ida Bells, we talk about the Alice Pauls, we talk about the Suffrage Movement, because again what comes is World War I, which we see much more active participation. You see that 300, 400 thousand women are actively 
participating in the war and I always tell the kids-- that gives them the perspective on what the men have seen. And at this point I point out, "Hey, Mars, Venus. Guys, girls don't look at this fighting thing the same way we do. They see that as nothing more than taking their men and their boys, and mamas don't like to lose their boys to stupid stuff." And so that is really where we begin the integration of the female empowerment and then of course, bam, what happens in 1919. We talk about the Suffrage Movement.

He went on to recount the other periods in which women's perspectives are included:

There's always — there's graphs—[like] Women in the Employment. And then, of course the aftereffect in the 20's ... and you say, "Hey, look, now we get flappers. Now not only our women integrated into the workforce, they've seen war, they're voting... [and] what are they going to think about now? No more war. So, what happens in 1920? Isolationism, the politicians move towards the domestic. We see the flapper. Now the woman is becoming an independent unit. She is autonomous of the male. This would be where the lesbian movement would get a little bit more empowerment. If you look at women like Amelia Earhart- it is not out there but—not in a derogatory way, you understand. I don't mention that in that way. But I say, "Hey look, this is probably where this is coming because now we see women saying I don't need men." And this of course is where I always foreshadow Feminine Mystique. [Then we] get to Gloria Steinem. You are going to get Feminine Mystique. Now, you're going to get all of these things in the 60's and of course I have to back shelf that. When I get into the 60's, I can say "Hey, remember we talked about this coming out of World War I and then proceeding 
up to through the 20's-- then I have talked about the Great Depression and things like that. I always mention the fact that the men moved and the women were stuck, and of course I show the iconic pictures of the woman with the baby and the shanty, I am sure you have seen it. We speculate about that. Where's the man? What's happened here? What sort of trials would that put on the female? And those types of things. And then we move through into the 40's where we're mostly talking about pre-war, we are talking about Hitler and Imperialism so again we lose the women to a certain degree. Then we talk about World War II. And when we talk about home front, then we're obviously talking about women and then I've got Rosie Riveter-- that is obviously a match made in heaven stuff. And then of course we talk about coming out of that. Oh, I failed to mention, I do always include Mary McLeod Bethune in all of my discussions about FDR and the New Deal with those types of things.

Ned subsequently listed the many females he is able to include in his lessons, including: Eleanor Roosevelt, Ethel Rosenberg, the Little Rock Nine (Elizabeth Eckford), Helen Reddy and her song I Am Woman, Rosalynn Carter, Madonna (of whom he said, "You can't deny the Madonna factor in empowering women, empowering girls. It is a sort of adverse way. I don't know how she did it, put her underwear in the outside, but it works. God Bless Madonna"), Jasmine Guy (from The Cosby Show), Monica Lewinsky, Fawn Hall, Barbara Bush (who he categorized an “evil queen”), Josephine Baker (during the Harlem Renaissance), Sandra Day O'Conner, Nancy Pelosi, Hillary Clinton, and Geraldine Ferraro.

It is interesting that Ned spoke for over 20 minutes about all the women he includes in his lessons. Though some of his information was faulty, he established a dedication to cultivating a 
culture of inclusion through his lessons. From his own schooling, Ned remembers only learning about Dolly Madison and Betsy Ross. He said he did not realize the level of exclusion from his own education until he went to college.

So here I am coming out of that Eurocentric school system and matriculating at a fairly high level. And realizing, as I get to college, that there's a whole other world out there. And that, bam, you go to UF and there's 36,000 people. There's all sorts of diversity.

Once Ned went to college he became more aware of the stories that had been left out of his own schooling. He considered himself to have a unique perspective of "always liking to look at things from all angles" which made him more apt to include those perspectives in his own classes. When asked directly why he included so many women in his lessons he answered: I'd like to say it's because they tell me I have to. But I don't think it is. I think even if I didn't have to, I would because half my classroom, more than half my classroom or at least half the school is women. And even the guys, guess what they have? Moms. They have sisters. So it's like hey, guys, don't forget, give them a little shout out. When you go and play guns, they got to stay home and take care of the babies. Oh yes, and go and make the bombs. And go make the planes.

According the standards that make up Ned's curriculum, he is not required to include nearly as many female perspectives as he describes. For the most part, Ned was very egalitarian in his views of inclusion. It was not until he offered, as one of the reasons he includes women, as to "give them a shout out" for "staying home and taking care of the babies" while the men "go play guns" that illustrated Ned's ambiguity on women's roles in history. 
For his own children, Ned wanted to teach them how be self-sufficient.

Like my boys, I'll try to always teach them-- you should be able to cook something. You should be able to do your own laundry. You should be able to sew. Do things for yourself. Don't be relying on somebody. Remember, so, when you know when you're not doing it, someone else is doing it for you. Guess who that is? A woman.

This seemed to come from Ned's own upbringing. He was very aware of the hardships his mother faced while his father was traveling in the military. When it came to his daughter however, Ned believed she was growing up to be "strong woman" just like his wife—who, as he put it, "wears the pants in the family."

Politically, Ned felt as though he was very centrist. He considered himself more conservative when it came to issues of national security and fiscal issues such as budgeting and "entitlement" programs, and more liberal about social issues. He said that he believes pay inequity is a "travesty" and never understood "machismo." Additionally, he noted that he was not sure the country is ready for a female president, though he did not have a preference either way.

Now, politically, I don't know-I don't know if the country is ready to elect a woman president. I don't care. Anybody, anything different. What the hell. Let's try black woman, Asian woman. What the hell. It can't get any worse, right? Seriously. I guess you see where I'm at politically. I am just fed up with the entire system. It just needs to explode and start over because it is just become an 'us and them' kind of $s^{* * *}$ and goes back and forth. 
Again, Ned demonstrated multidimensionality in his view on female leadership. While he noted that he did not care whether a woman was president, he qualified that by saying "it couldn't get any worse." While this may not have an impact on his motivations for including women's history in his class, it does speak to the possibility of sexism lying within the hidden curriculum in Ned's classroom, in the semiotic structure of his lessons, and in the way he speaks to his students.

Outwardly, Ned agrees with the concept of feminism, which he considers the "idea that woman can be independent of men and be just as functional as men" a "valid concept. Yet, when asked if he considered himself a feminist, Ned did not.

To the degree that I go and marched for women's rights, no. I mean, if someone said to me, do you believe women are equal to men? I would say, "Absolutely," and I would even go as far as to say in some ways more equal. And in some ways less equal. It's the alternative perspective. I am sorry, that's all you're going to get from me. There's a dissociative, I think, [there is a] misnomer associating that with maybe lesbianism or stronger female.

Ned had negative connotations associated with the term feminism, thus even though he was teaching in a way that could be categorized as feminist in nature, he would not fully accept the label for himself. When offering his final thoughts at the close of the interview, Ned expressed that he did not believe the inclusion of women in history was something that needed to be "too critically focused on" since he knew he was doing a "fairly good job with it" on his own. 


\section{Classroom Observation}

Prior to the observation beginning, Ned Hudson told me that part of what he was planning for the day was to do a review, but part would be a "dog and pony show" for my benefit. He opened one door for me as we are walking to his classroom, then at the second door he did not open it, saying that after our interview he had taken notice of all the things he does, and that makes him think.

Students arrived to Mr. Hudson's class and took their seats. As they entered the room, Mr. Hudson had music playing (a male singer). He told the students that next week they would be taking a test on the 70's and 80's.

Mr. Hudson: What did we do last week? Today we are going to review, this is all review.

He wrote on the board:

1) Name a 70's Fad

2) What is OPEC?

3) How did the 1973 OPEC oil embargo affect the U.S. economy?

4) Explain the relationship between 70's fad and the counterculture of the 1960's.

Mr. Hudson: $\quad$ You can see that I have a never-ending quest to talk about hippies from when I was growing up. 
The table below shows student response to the questions above:

Table 7: Hudson- Student Responses to Questions 1

\begin{tabular}{|c|c|c|}
\hline Question & $\begin{array}{l}\text { Gender of } \\
\text { Student } \\
\text { (T=teacher) }\end{array}$ & Responses \\
\hline \multirow[t]{12}{*}{ Name a 70's Fad } & $\mathrm{T}$ & Pet rock \\
\hline & $\mathrm{M}$ & Afro \\
\hline & $\mathrm{M}$ & Platforms \\
\hline & $\mathrm{F}$ & Bellbottoms \\
\hline & $\mathrm{M}$ & Female hairstyles \\
\hline & $\mathrm{M}$ & Flapper \\
\hline & $\mathrm{F}$ & Leisure suits \\
\hline & $\mathrm{F}$ & Lava lamps \\
\hline & $\mathrm{F}$ & Mood rings \\
\hline & $\mathrm{T}$ & Etch-a-sketch (Mr. Hudson) \\
\hline & $\mathrm{F}$ & Neon posters, black lights \\
\hline & $\mathrm{M}$ & Speak and spell \\
\hline What is OPEC? & $\mathrm{M}$ & OIL \\
\hline \multirow[t]{3}{*}{$\begin{array}{l}\text { How did the } 1973 \text { OPEC oil } \\
\text { embargo affect the U.S. } \\
\text { economy? }\end{array}$} & $\mathrm{T}$ & $\begin{array}{l}\text { Oil supply decreases, when supply goes } \\
\text { down, prices go up. It's supply and } \\
\text { demand. }\end{array}$ \\
\hline & $\mathrm{F}$ & $\begin{array}{l}\text { I have a question, how much oil do we } \\
\text { have? }\end{array}$ \\
\hline & $\mathrm{T}$ & Not enough, but I don't know. \\
\hline \multirow{4}{*}{$\begin{array}{l}\text { Explain the relationship } \\
\text { between } 70 \text { 's fad and the } \\
\text { counterculture of the } \\
\text { 1960's. }\end{array}$} & $\mathrm{M}$ & Traditional clothing \\
\hline & $\mathrm{T}$ & Etch-a-sketch influence \\
\hline & $\mathrm{T}$ & $\begin{array}{l}\text { I just remember, I had this teacher in } 4^{\text {th }} \\
\text { grade with a guitar and non-hygienic } \\
\text { genital habits. She would get out her } \\
\text { guitar and start singing all the time. }\end{array}$ \\
\hline & $\mathrm{T}$ & One of the parts of culture is gender. \\
\hline
\end{tabular}

After this exchange, Mr. Hudson began a PowerPoint presentation about the Women's

Movement. The presentation began with a quote from Sun Tzu's Art of War: "It is said that if 
you know your enemies and know yourself, you will not be imperiled in a hundred battles; if you do not know your enemies but do know yourself, you will win one and lose one; if you do not know your enemies nor yourself, you will be imperiled in every single battle." Mr. Hudson read the quote aloud, but did not discuss its meaning, or its relation to the rest of the lesson.

Slide B showed a women's power symbol, but was not addressed by Mr. Hudson in regards to meaning or relation to content.

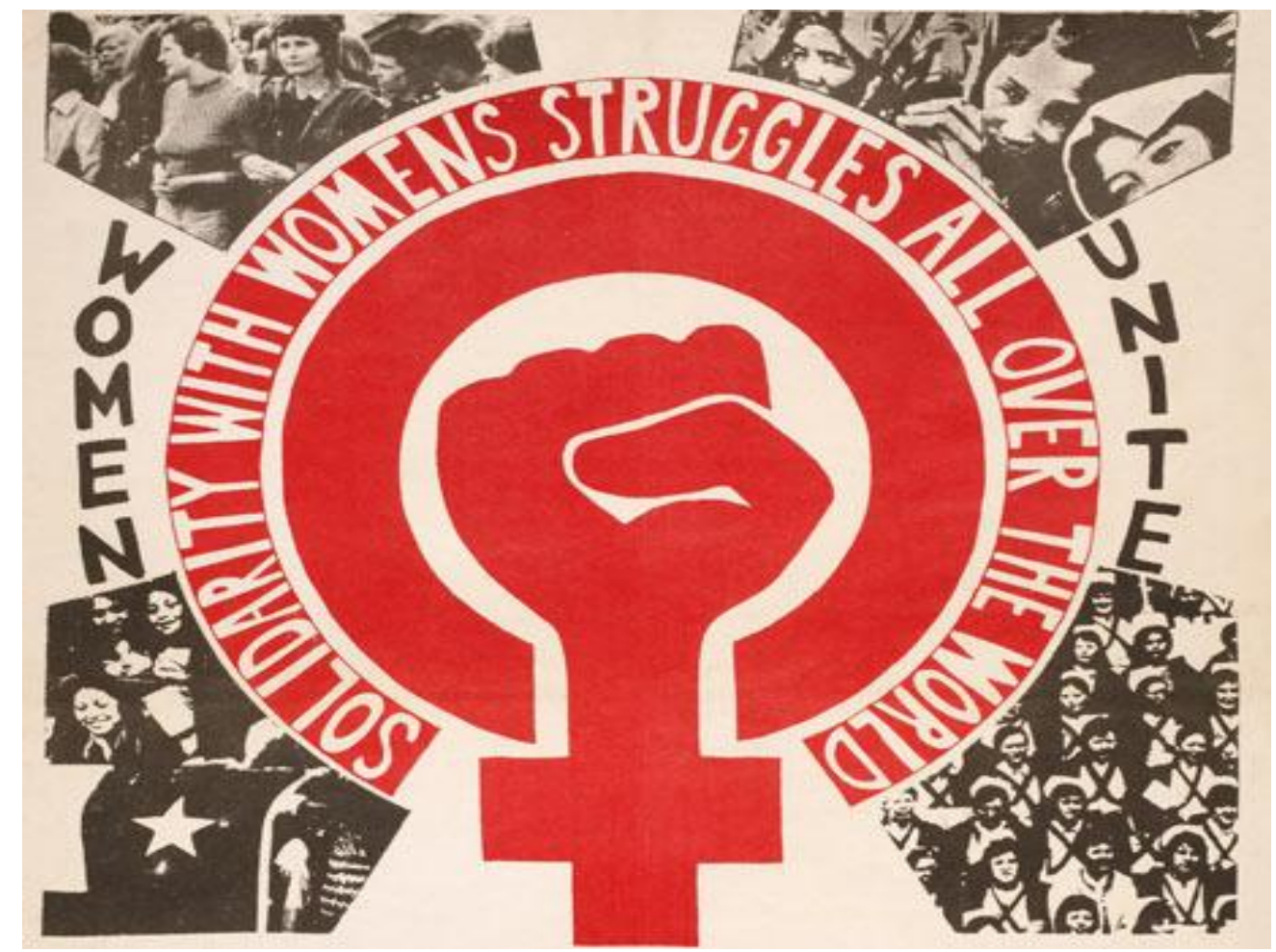

Figure 1: Slide B- Women's Power Symbol (from Mr. Hudson's PowerPoint presentation)

The next slide provided a list of vocabulary and definitions, which students copied as Mr. Hudson gave some further information about several of them. Below are the words and definition as they were given on the presentation: 
Feminism: a collection of movements and ideologies aimed at defining, establishing, and defending equal political, economic, and social rights for women. This includes seeking to establish equal opportunities for women in education and employment

National Organization for Women (NOW): organization formed in 1966 to promote the full participation of women in United States society.

Betty Friedan: Feminist author and activist who criticized limited roles for women in her 1963 book The Feminine Mystique. She later founded NOW.

Equal Rights Amendment (ERA): proposed constitutional amendment (never ratified) to prohibit discrimination by sex.

Mr. Hudson: feminism is a word that has been much maligned in my lifetime.

Mr. Hudson: $\quad$ The Feminine Mystique asked women if they were bored. No duh they were bored.

Mr. Hudson: Did you know women couldn't have cars?! You should thank Betty Friedan and Alice Paul for that right. 


\section{FIGURE 5. NUMBER OF DIVORCES PER 1,000 MARRIED WOMEN AGE 15 AND OLDER, BY YEAR, UNITED STATESA}

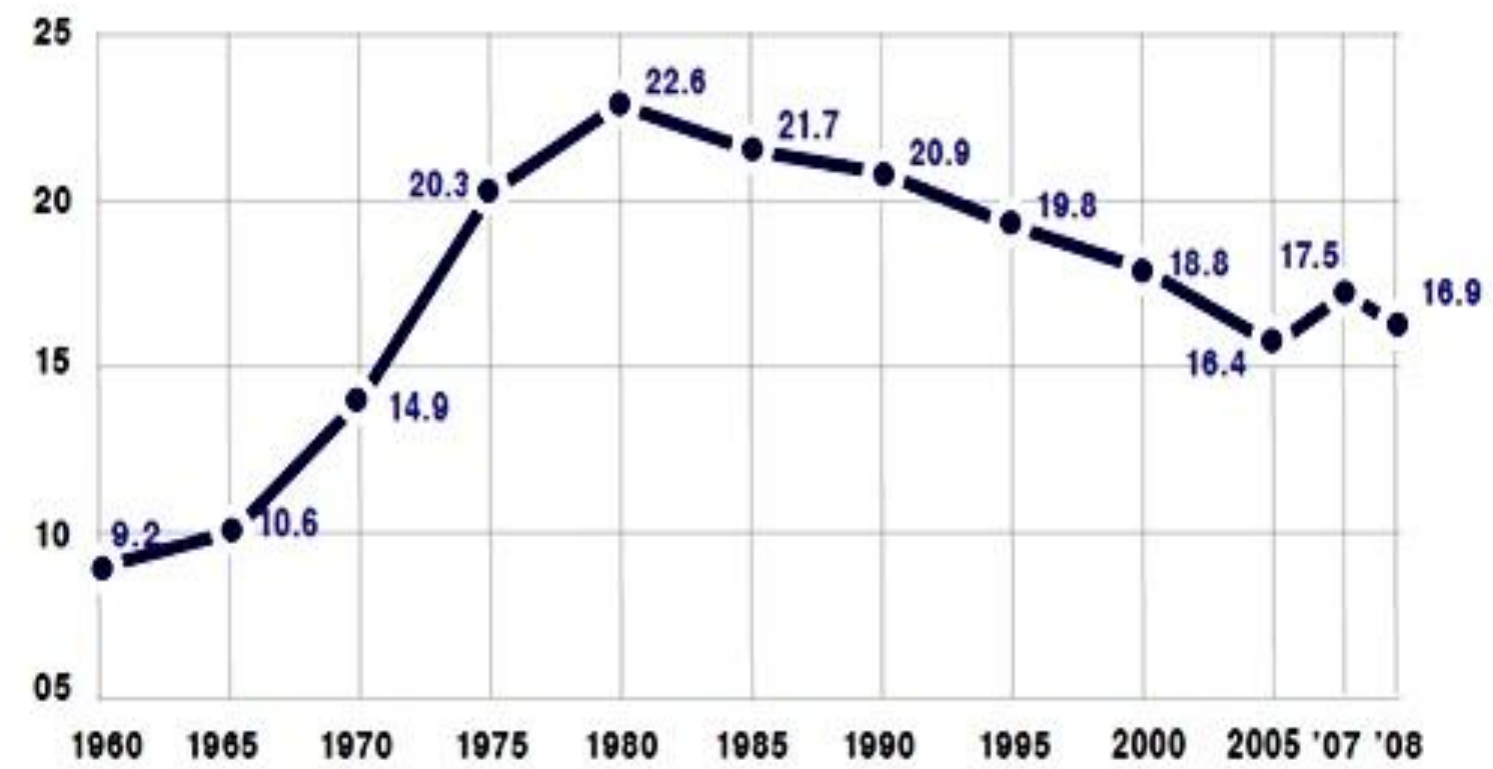

Figure 2: Slide C- The Divorce Rate Over Time

Mr. Hudson: What happened in 1960 that could have caused the rise in divorces?

[pause] The birth control pill was created. Why was that important?

[pause] Because women were having more freedom. What is Roe v.

Wade? [pause] The legalization of abortion in 1973. 
Next, Mr. Hudson discussed the rise in divorce rates through the 1970's and 80's.

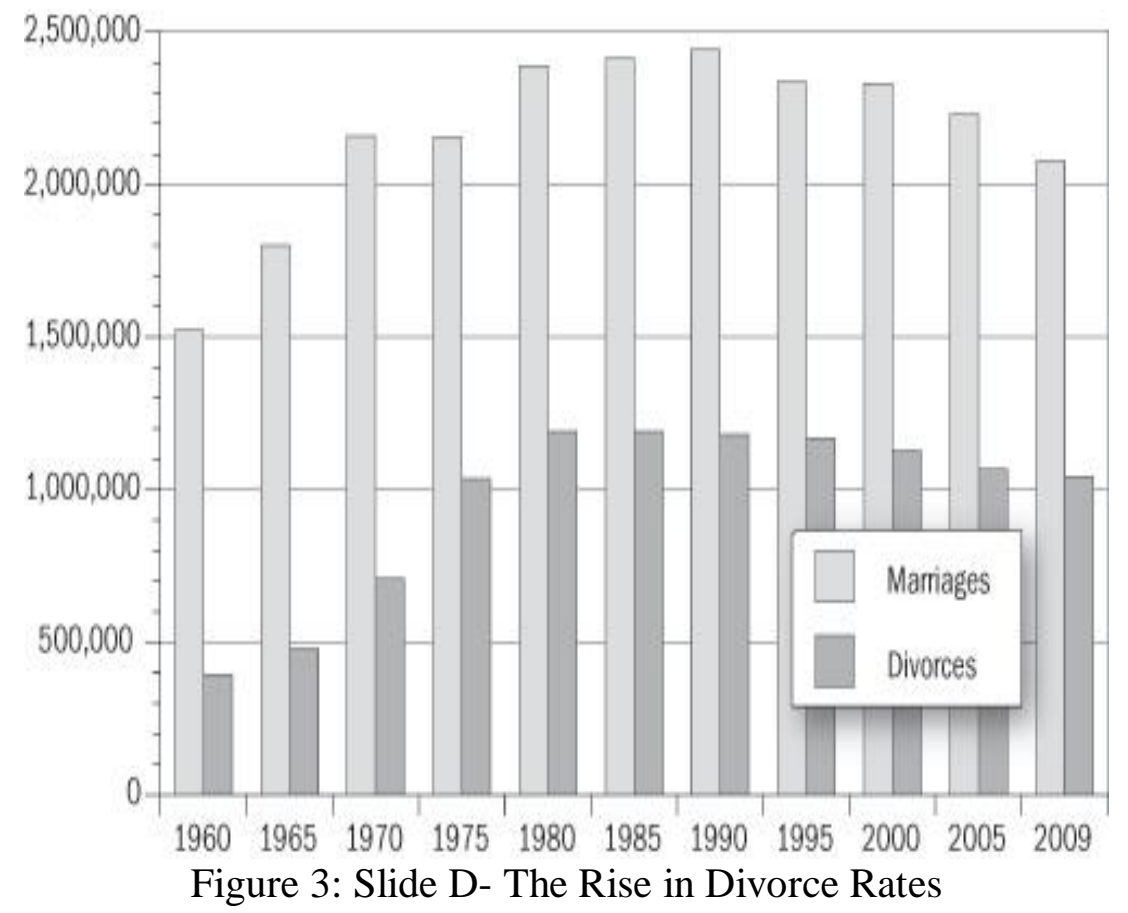

As he was talking about the rise in divorce rates, Mr. Hudson mentioned the impact of media on culture and indicated to his class that there were a number of television shows in the 70's and 80's that involved single mothers such as One Day at a Time and Alice.

Mr. Hudson: $\quad$ This was the first time Americans were seeing diversity on TV, first with The Jefferson's and now with women, strong women without a man. Furthermore, it demonstrated an acceptance in mainstream society of single women with kids, with power.

Following Slide D, Mr. Hudson showed a YouTube video of the opening sequence the television sit-com One Day at a Time, pointing out to students that the women were on their own and happy, the mother character looked free. He paused the video to point out Valerie Bertinelli 
introducing her to students as "Mrs. Eddie Van Halen, rock guitarist." He also noted to the class that this change, women being independent and free, was due to hippies entering society with their motto, "peace, love, let's accept everyone."

Mr. Hudson then talked about how the Catholic Church did not let his aunt go to communion because she was divorced.

Mr. Hudson: $\quad$ Would this have sociological impact? I would say yes.

It is worth pointing out that during this lecture, Mr. Hudson answered all his own questions. There was no student talk during the presentation of information, no questioning, and no answering of questions.

The following two graphics from the Heritage Foundation were presented without much description. It was as if Mr. Hudson did not have much prior knowledge about the material he was presenting. The Heritage Foundation bills itself as a "research and educational institution whose mission is to formulate and promote conservative public policies based on the principles of free enterprise, limited government, individual freedom, traditional American values, and a strong national defense" (Heritage Foundation, 2013). 


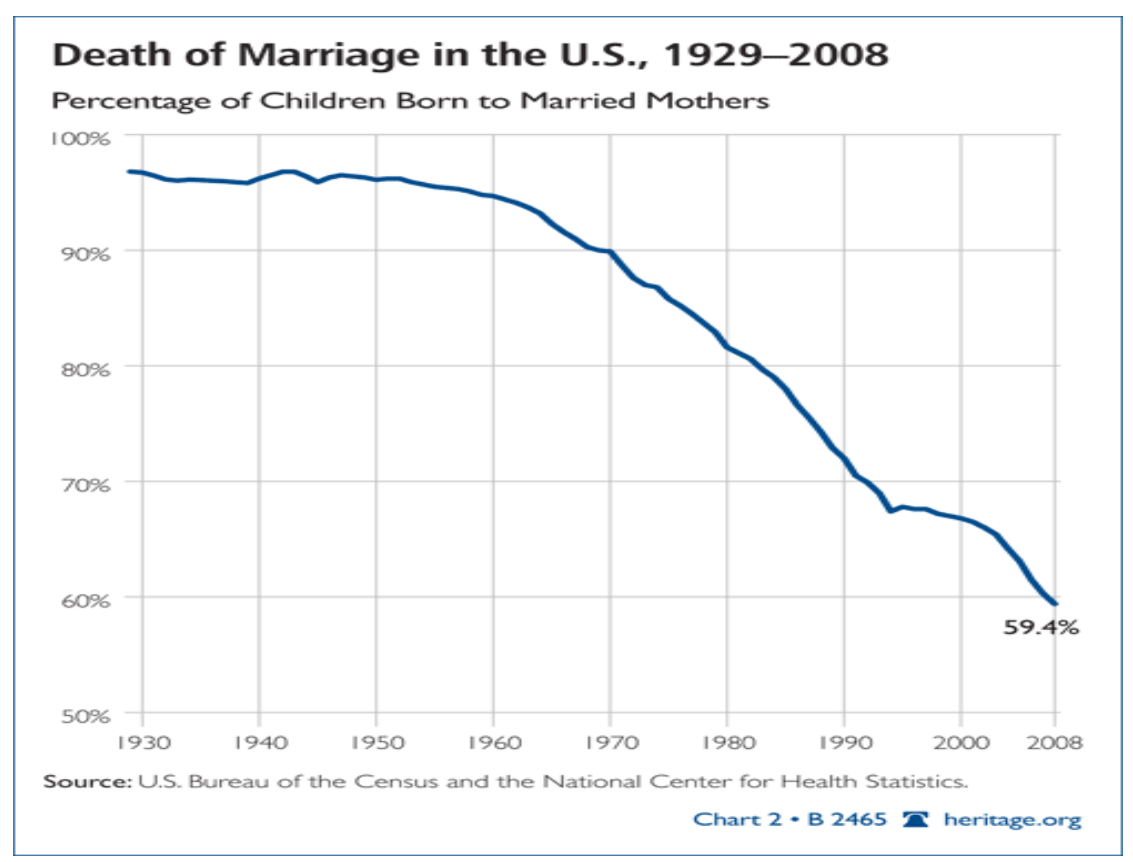

Figure 4: Slide E- Death of Marriage in the US

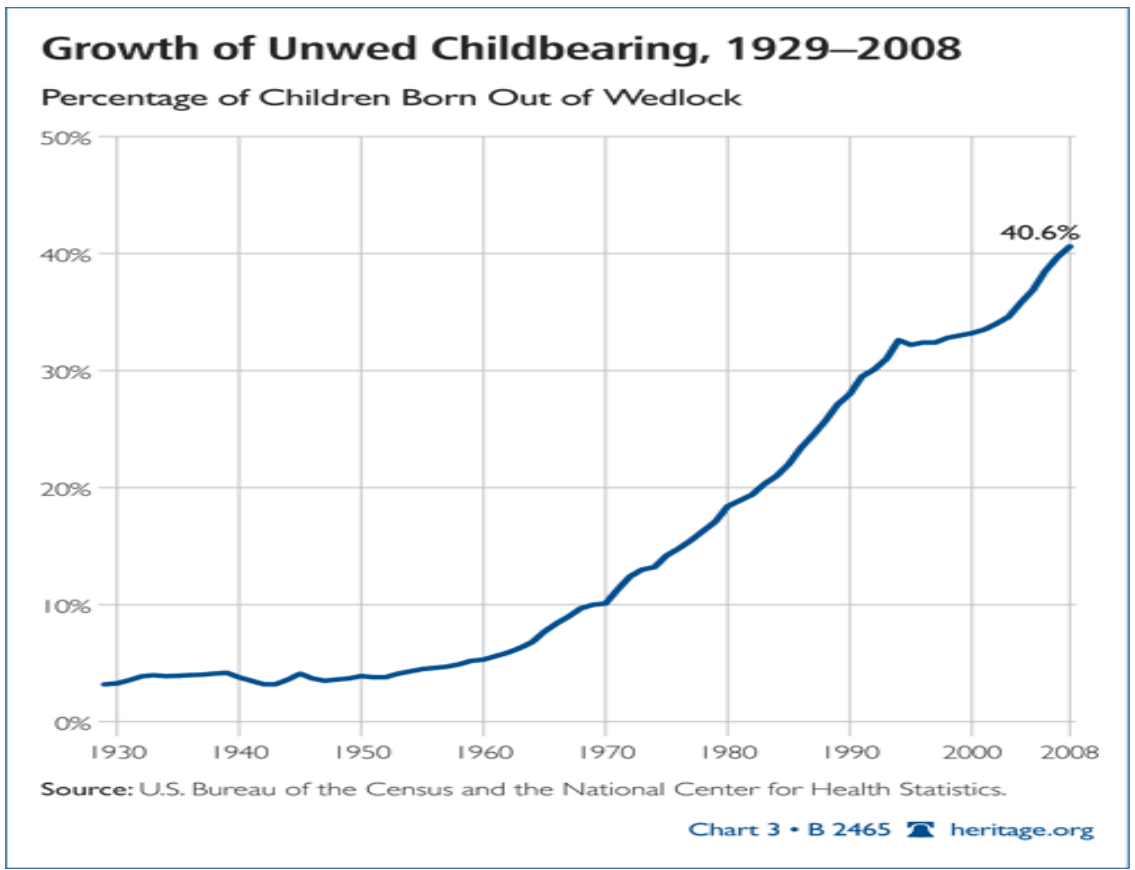

Figure 5: Slide F- Growth of Unwed Childbearing

These two slides, presented without much discussion, other than mentioning their titles and describing what they illustrated, actually contain loaded language that went unaddressed in the 
lecture. The purpose of included these slides was not apparent, however, it did appear that they were included without purposeful thought to the subtext.

Subsequently, Mr. Hudson showed a news clip from 1992 in which Vice President Dan Quayle spoke about the television show Murphy Brown and how having children out of wedlock created many problems in society, including the riots that occurred in LA that year. The final note from the newscaster of that piece was, "the producer of the show Diane English responded, 'If Mr. Quayle thinks it's wrong for unmarried women to have a child, then he better make sure abortion remains safe and legal."” However, like with the slides before, no class discussion occurred following the video clip.

\section{Earnings in Relation to Similarly Educated Men's Earnings}

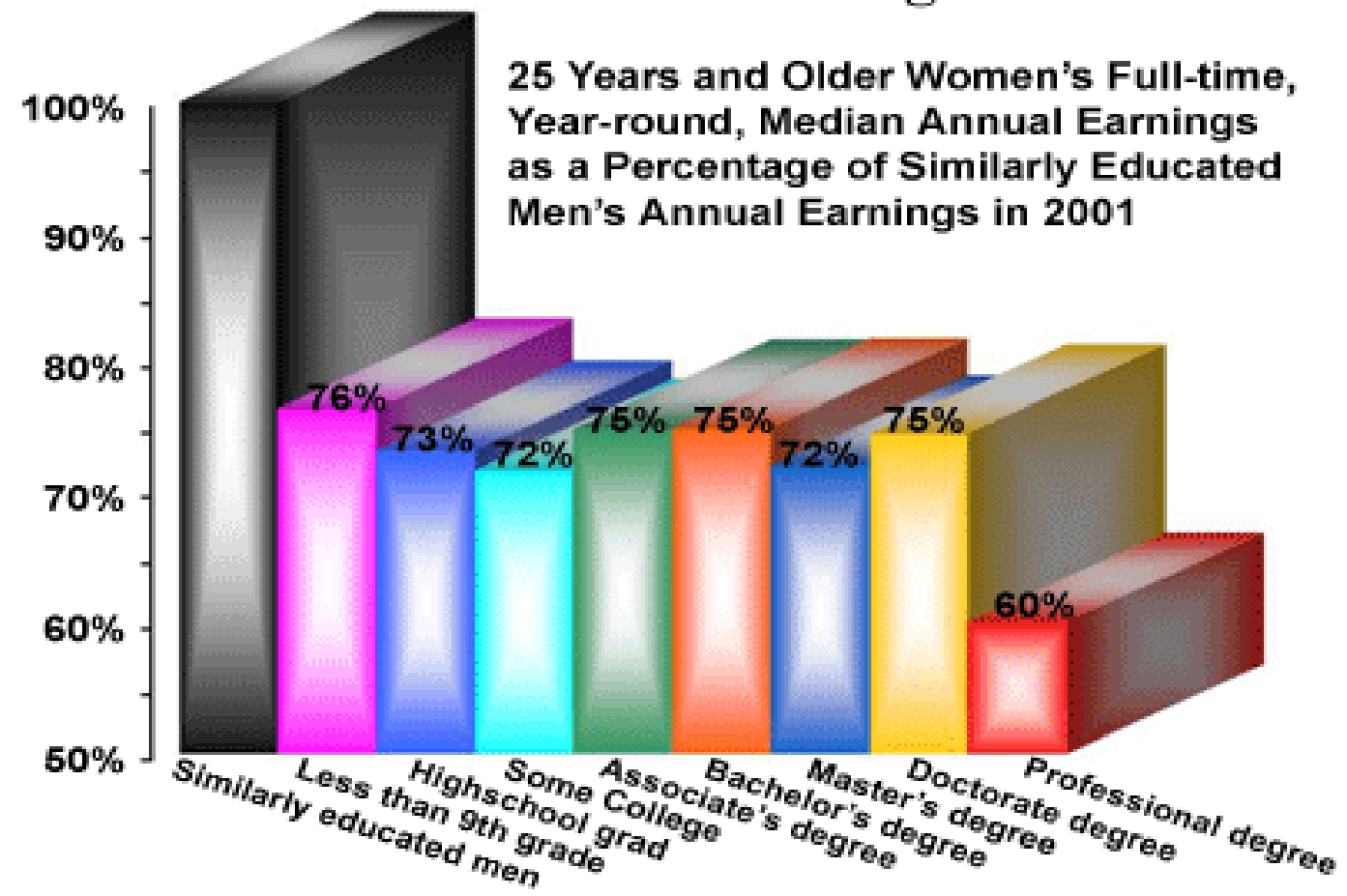

Figure 6: Slide G- Earnings in Relation to Men's Earnings 
Slide $\mathrm{G}$ was displayed as Mr. Hudson pointed out to students, albeit faultily, that the difference in pay would be such only if they received their doctorate, saying, "if you can get through that." Meaning he was looking at the numbers in the wrong manner. Where it says those with a Professional degree earn $60 \%$ of what their male counterparts earn, he indicated to students that the difference was less than those who had lesser degrees. This discrepancy did not make a substantial difference to the content of the lesson; however, it is worth noting that not a significant amount of attention was paid to the details of the charts and graphics Mr. Hudson included in his presentation.

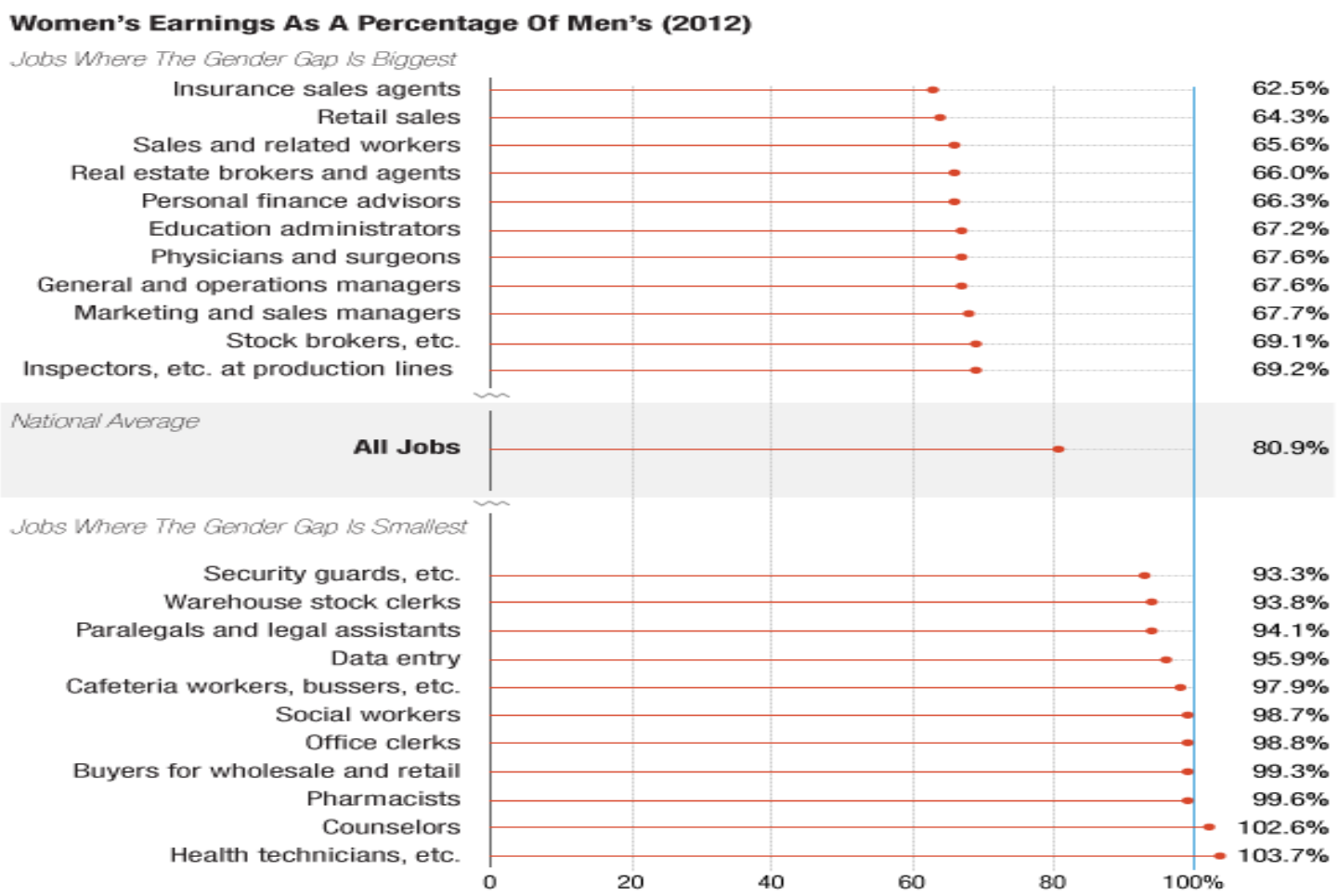

Figure 7: Slide H- Women's Earnings as a Percentage of Men's 2012 


\section{Figure 2. Annual Median Income Levels by Race and Gender, 2009³}

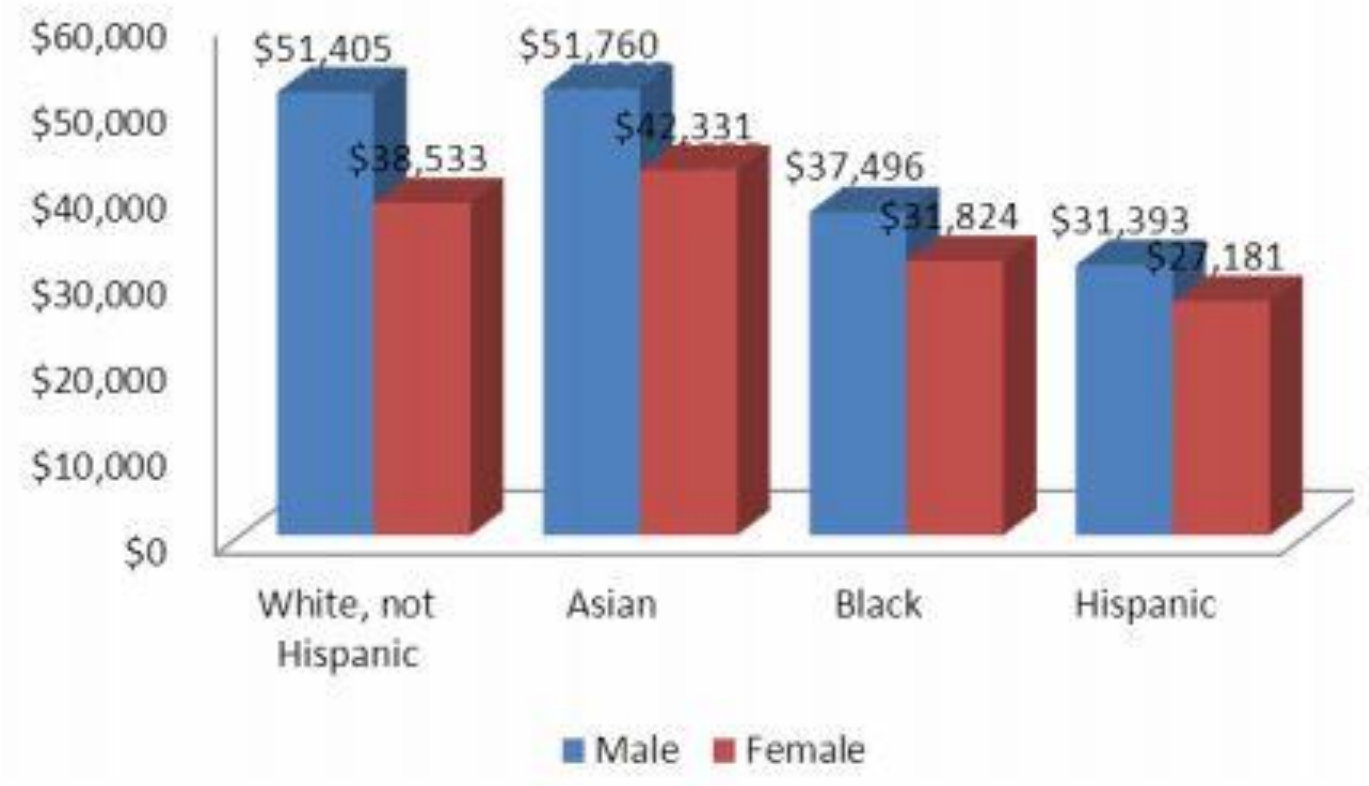

Figure 8: Slide I- Annual Median Income Level by Race and Gender 2009

Slides H and I, were shown with no comments from Mr. Hudson. He read the titles only.

Mr. Hudson: $\quad$ How many of you come from single mother homes?

Approximately 10 students raise their hands.

Mr. Hudson: $\quad$ Back in my day, that would only have been one or two.

Here is the last question, We'll pretend that I am a real teacher, and answer this on paper: "Predict what sort of impact the divorce/single family household increase in the 1970's might have had on U.S. society today." 
Female student: If Dan Quayle is against single motherhood, why is he attacking TV and not society?

Mr. Hudson: $\quad$ Mass media, glorification of single motherhood.

In this lesson, Mr. Hudson demonstrated the manner in which he brings women's history to his curriculum. Though he admitted prior to the start of the lesson that it was a "dog and pony show" on my behalf, taken at face value, the lesson itself would align with Tetreault's "Feminist History" stage in her "Stages of Thinking about Women in History." This stage is defined by its "pluralistic conception of women...which acknowledges diversity and recognizes that other variables besides gender shape women's lives, e.g. race, ethnicity, and social class.” Here, “women's experience is allowed to speak for itself. Feminist history is rooted in the personal and the specific; the public and the private are seen as a continuum in women's experiences." Furthermore, "Women's experience is analyzed within the social, cultural, historical, political, and economic contexts" (Tetreault, 1986a).

Beyond the content of the lesson, Mr. Hudson actual classroom demeanor was not feminist in nature. His mention of his own fourth grade teacher's "genital hygiene" was highly inappropriate and might have made both female and male students uncomfortable. The dynamic of the class was such that it was clear, Mr. Hudson was the arbiter of knowledge and students were there to listen to the stories. This is common in high school history classes; however, it does not cultivate the open environment of an egalitarian classroom. 


\section{Jeffrey Emerson}

Jeffrey Emerson works at a school for "at-risk" students, where he teaches Economics and U.S. History. He is an African-American male in his late 30's, who grew up in California with a single mother and later, a military stepfather. At the start of our interview, Jeffrey believed that this study was about the inclusion of African-American perspectives and Civil Rights. When we began talking, he spoke passionately about his family history with Jim Crow laws, the efforts in the Civil Rights Movements, and the importance to relaying these stories to his students. Although he agreed to continue our interview once he knew the actual topic was about the inclusion of women's history, he did eventually withdraw from further participation and did not agree to be observed teaching a lesson. Jeffrey's interview did not proceed as easily as the other participants did, and it was obvious he was disappointed in the topic once it became clearer to him.

Jeffrey indicated on the survey that he included women's voices once a week in his lessons; nevertheless, after several attempts to schedule an observation, I received an email that stated the following:

First, I would [like] to thank you for the opportunity for allowing me to participate in the study for women. However, I will not be able to participate any further in your study. Due to the current deadlines for seniors, district tests, and personal matters. I would like to apologize for any inconvenience that I may have caused.

Taking the email at face value, Jeffrey had several reasons for wanting to abstain from further participation; however, I believe the topic under study was also among his motives. In any case, 
I have included information from the interview but for obvious reasons, there is no observational data on Jeffrey.

To begin our interview, I asked Jeffrey how he approached the social studies curriculum when it came to including multiple perspectives.

For example, if we are talking about the 60s era, it comes to do with civil rights...you're either against it or you were trying to stop it from happening. Because you are afraid that something was going to happen to you and your family. I can attest to this because I had a lot of relatives in the civil rights era [who] marched and protested. And I can remember vividly talking to my uncle, and him, distinctively talking about an issue when it came to Jim Crow and the way minorities were treated, and how angry and violent certain people who believed in Jim Crow were. [They] were adamantly against Martin Luther King and felt like he was the lightning bolt or communist, as which they call him or a trouble maker or "uppity". That was a term in the south that was constantly used and had a profoundly negative effect. Certain people were scared that they were going to be target, like for example, when my uncle was getting ready to march, the grand wizard of Mississippi [approached him]. To hear him, and [to] distinctively hear this from my uncle, saying... he can name my grandmother, the [place] where she worked, he can name what time she got off of work, where she went to and who dropped her off at the exact time. For him to know that, somebody in the government must have told him. And then he had somebody watch my grandmother for a couple of days, that can be very scary. Because if they have that much time to locate you and your family members, that is a horrific 
treatment or torture that they can use to get you out of protesting, to get you scared [so] you don't protest because of fear of change. So, when he told me that and he told me that's the reason he left Mississippi, that made me worry.

Clearly, Jeffrey was interested in discussing his family history and its impact on his teaching practice. Thus after I debriefed him on the actual purpose of this study, much of what he offered seemed to be what he thought I wanted to hear. We began with him telling me why he chooses to bring in women's perspectives.

Okay, the reason that I bring in women's perspectives a lot, I had a strong mother. I had a very strong grandmother and a lot of women who [were] around me were strong. I guess I saw it from the term of... including my dad's mother. You know, just the way they handle certain situations, it was just incredible. You know, to be a woman in the time of basically not being able to voice your opinion, being cuddled to the concept of being barefoot and pregnant at home, not being educated, refusing to listen. My mother was [of] a sound mind that education is basically what you make it. Sometimes, you can't just sit back and expect it to happen. You have to make it happen. And I think it was one lesson that really got me. She was like a... I kept telling her, I said, "I want to be an [extra]ordinary person." She said, "There are no [extra]ordinary people but there are ordinary people that do extraordinary things." She said, "If you want to be one of those people, you can't think on the terms of ordinary but you got to think on the terms of extraordinary and when you look at this, and you look back at this, you won't be mad at me for it but you're mad at me now." 
He then told a protracted story about when he was in the $6^{\text {th }}$ grade, and was retained. To teach him a lesson, his mother put him in special education classes so he could see that by not reaching his intellectual potential and getting by being retained a year, people would not respect his intelligence.

Additionally, Jeffrey had a grandmother who taught him to value reading. She would read books with him, Tom Sawyer and Hansel and Gretel, and "a lot of leadership books." Again, here, Jeffrey discussed how his grandmother taught him about racism:

And then she would talk about, you know, the perspectives of different people and how the way they were treated, and you know, she would talk about her experiences, as made from the University of Alabama and she said, "Some people are very nice." She said, "some people are masquerading like they're nice and they're not, and they're racist. You can usually tell that and you can tell that by 2 different ways." She said, "Number 1, they'll eagerly say. Okay. Give you a little front but they will never invite you to their house. They will never come and visit you." So much is like, they want to keep a separation between the two. She said, "But it doesn't matter." She said, "Long as you know what it means."

It was obvious here that Jeffrey had a story he wanted to tell, and this study was not going to give him the avenue he had hoped it would to get his story out. I asked him how his grandmother influenced him to include women in his lessons. One way he related was by being “adamantly Pro-Choice."

She said, "Women have the right to choose." She said, "no one has the right to tell you what you can't do and what you can do." She used to tell me about the 
days when women were not allowed to [get] abortions... while they were lying on the table and they were bleeding to death on top of the table.

Jeffrey believed she had presented this information at a time when he was beginning to show interest in girls, to teach him about the consequences of impregnating a woman. This brought us to Jeffrey's thoughts on family and gender roles, on the importance of treating women "right" and on the impact men have on women overall. From the lesson Jeffrey took from his grandmother, he said, "it's not just that a husband leads, but it's a partnership, and it's very important because it solidifies that woman's life."

Much of what followed in our interview revealed a paternalistic attitude Jeffrey had toward women in general and the females in his classes. When it came to relationships, Jeffrey indicated that he believed women needed men and one of the most important lessons he learned and hoped to instill in his female students, was the imperative for a lady to be a lady. From his maternal grandmother, Jeffrey learned of family:

You can't break it. But when you start separating [from] each other, it has a direct effect on women in general because they need males. They need leadership. They need love just like everybody else. She said, "When you insult them, it has a direct effect on that woman's life." She said, "Remember that when you're teaching kids. Remember that when you're showing young ladies how to be ladies."

From his paternal grandmother, Jeffrey took the following lesson:

She said, you can always tell between a trashy woman and a lady, the way that she treats her father, the way that she treats her brother, the way that she treats her mother and sisters. She said, a lady is going to introduce you as a man. 
This idea of the "trashy woman" became somewhat of a theme in our conversation. Jeffrey discussed his beliefs about marriage and why he feels that it is important to treat women well, particularly, the woman one is married to:

It's inherently important the way you treat your wife because if you treat your wife well, you know, you're going to blessed for it because your wife is going to have a good life and you're going to have a good life. Because if your wife is mentally unstable, she goes to work fragile, scared like you're jumping on her and yell on her causing that, and her life is dysfunctional. Guess what, you are responsible for her being like that. And that's a huge responsibility for you. Your wife should be happy. She should be comfortable and she should be ready to back you.

Having a wife who is "ready to back you" proved vital to Jeffrey. When he discussed his own wife, he pointed out how she supports him throughout his life.

She stands with me no matter what. I'll walk into the house and she'll ask me how my days go, and I'm not stating we're perfect...but one thing I can expect, she always has my best interest. She is always looking out for me. She's always looking for me to get better. She's always looking for me to speak better, read more, get more fit. Financially better. Get a job promotion. She is taking care of my son and [has] done everything as far as my education. [Through] my master's stayed home and supported me through getting my EDS. To [have] a good wife who is not only beautiful, but [also] very intelligent is, you know, a blessing. 
Through this exchange, Jeffrey expressed his value for a traditional gendered relationship. He discussed the importance of having a wife to support his goals, to take care of his child, and to be both beautiful and intelligent. Much of what he expressed in what he valued about his wife, was what she did for him. This theme also appeared when Jeffrey was discussing teachers who had an impact on his life.

The first teacher Jeffrey credited with influencing him was from when he was six years old. Back then, Jeffrey did not like to read but this particular teacher would give him "little candy bars and put little stars on my paper." He expressed that her acknowledgment of his improvements made him appreciate her more. "It was like somebody was actually in my corner as teacher, saying that you can learn, you can get better."

Another teacher that Jeffrey credited with affecting his life was his eighth grade teacher who instilled a love of history. At first, he was not a good student for her. It was not until this teacher, Ms. Brown, went out of her way to discover what Jeffrey enjoyed, and prepared a lesson to suit his needs that was able to appreciate her.

Now, Ms. Brown thought if she can get me under control, she can get the class under control, so I was like, I was real hesitant. I think I didn't speak to Ms. Brown for a whole week, just wouldn't talk to her. I'm just mad. Wouldn't do any work. She said, alright, go home. She did that for a whole week. I got to Monday just doing this one particular assignment. You know, I really love history and I really love hands on and acting out. She's had read that in my file, so she put together this, dress as a pilgrim, whatever, she bought the costumes. So, [I] got up as a pilgrim and I did my little speech and I loved it and from that point, she had me. 
As with his other teacher, and his wife, Jeffrey placed value on these women once they demonstrated that they had his best interests in mind. However, none of these stories indicated the motivation for why Jeffrey claimed to include women's perspectives in his history classes.

In order to better understand how Jeffrey came to value include women's history, I asked him about which women he remembered learning about when he was a student. The first women Jeffrey named, were Shirley Chisholm and Rosa Parks.

I'd remember distinctively, taking about [them] a lot and just you know, what they were dealing with as minority women and dealing with issues not coming from [just] as a woman but dealing with everything [that] comes with color. You know, how they adjusted to it and what they were putting up with. You know, they were putting up and losing their family and making trouble because their husband could lose [his] job. I didn't know that. But they were actually putting everything on the line. You know, like heroes.

Even here, when discussing women who he believed were "like heroes," Jeffrey still discussed how their accomplishments affected their husbands. This indicates that Jeffrey places value on women who fulfill their wifely duties even when their role in society is not related to their role at home. In addition to Shirley Chisholm and Rosa Parks, Jeffrey said he remembered learning about Hillary Clinton, Nancy Pelosi, and San Diego mayor, Maureen O’Conner. He also remembered learning about the Women's Movement for equal pay, reproductive choice, and overall equality.

In discussing why learning about women's equality held value to Jeffrey, he noted how females influences society and the future: 
We need to train young ladies to be women so we can have a better society because they have the children. If you teach them to be ignorant, guess what's going to happen to our children? Our children are going to be ignorant, scared, not being able to articulate themselves. And eventually, they're going to act like their father, abusive, injustice, narrow-minded as they are. Society will never change.

For Jeffrey, it seemed that he considered this study to be about educating women, not necessarily including women's history in the traditional framework. Much of what he said indicated that he was holding on to traditional gender roles, both in his personal life and in the manner in which he believed females should be taught in his classroom.

Jeffrey mentioned a lesson he taught his students that included women's perspectives in his American history class. This lesson came out of the textbook on the chapter on the Women's Movement. It was a stand-alone section, outside of the regular chapter, that provided two perspectives on the abortion issue; Gloria Steinem provided one perspective, Phyllis Schlafly authored the other. However, Jeffrey did not know who either of the authors were, or who was who on the "for" and "against" side of the debate. He also pointed out an inset within the text about Esmeralda Santiago, a Latina woman and her perspective on the women's rights issue. Of the lesson, he said, "They did a comparison and contrast on it and we talked about it and went into elaborate detail throughout it and that discussion just went sky rocket."

When asked about other units in history in which he is able to bring in women's history, Jeffrey mentioned discussing women in factories during World War II and a discussion he had with his students about women in Islamic countries, and about women in the military. 
Overseas, in the Islamic society, you have to walk behind the man. And I put it this way, I said, if you have a son, you have to walk behind him. You cannot overtalk him, not even in your own house. They [female students] were very aggressive towards that. They was like, "Not me. Dad just had to stone me to death." I said, yeah, they probably would. I say, you have to keep your whole body covered. Everything that you're revealing is a sin. And they were like, "what?" So we just, I mean, it goes. Like I try to involve those perspectives in because I have a lot of young ladies in this class and they don't realize their privileged here. They don't get it that, you know, you go somewhere else, you have to function a different way. When we talk about the issue of the military and a lot of them want to go into the military of basically wanting to be a part of it. I said, do you know that you had to go into a combat to be part and get ranked and they wouldn't allow women to go any further. Did you know just recently, they [changed] that law because of so many lawsuits? They were like looking at me like, Oh my god. I want to know how to fly a plane. And you know they were freaking out.

Jeffrey pointed out to students how their lives are different from women in the past, and women in other cultures, similar to the way Amy Wiggins focuses her lessons on how things have improved for women over time. Jeffrey's motivation to include women's history appears rooted in his personal beliefs about women's roles in the family.

It's very important for young ladies, because a lot of young ladies who were at school today somehow have low self-esteem issues, some are very shy. They don't know knowledge is power. The more knowledge that you have, the more 
articulate that you can be and the more that you can voice your opinions about things that you know are wrong, that people are doing them wrong, that you can stand up against. And the more people that we have to stand up against, the better society will be, the better your children will be, the better you will be, and the better your husband will be because you are basically the center of everything. Children, aunt, uncle, woman is the center of everything and they just don't realize that and it has a direct effect on family. You know, so when a woman or a mother is not right, the children and the husband are not right because she's making the wrong decisions. She's doing things that she's not supposed to do and she's not able to protect herself in a logical frame of mind. Bad decisions leads to bad life and bad life affects children which affects us as a society.

Thus, even when discussing how he includes women's perspectives/history, Jeffrey places the emphasis on women being the center of the home and needing to be educated in order to raise balanced children. He indicated that he teaches his female students to be "true women" including how they dress, speak, think, and articulate themselves.

Though Jeffrey did place an emphasis on equality, he would not characterize himself as a feminist.

I don't know if I was a feminist. I think I'm an advocate. In other words, I want to see it changed to the point where women have more rights. I still think we're living in the Stone Age when it comes to the way men treat women. You know? It's almost just like big women are a trophy. They're not a trophy, they're human beings. They deserve respect just like you deserve respect. If you were treated 
like that, you would get mad. And some men had been treated like that. They're too scared to come out and say anything. I don't say I'm a feminist. I'm like an advocate because I want to have the foresight, the vision to know [how] it's going to affect children and women in the future.

Though Jeffrey claimed that he wanted equal treatment for women, he was concerned that promoting a "feminist agenda" would create a society in which women would hold too tightly to their beliefs causing problems for children and families.

For his own students, Jeffrey stated that his agenda for the females in his class is to teach them how to be ladies.

I'm looking in for them to be ladies. I'm looking for them to always conduct themselves like a lady, you know, even with the way you relate to people, how you talk to people because you know, a nasty lady is known as the nasty lady, but a true lady is always going to be known as a true lady. She'll be respected as a true lady. I say, you need to make up in your mind, if you're going to be a trashy old lady or you're going to be the lady that somebody should treat you the way you deserve. And I was raised around women like that, so you know, I know what a strong woman looks like whether a woman... people of the night call, you know, but you have to be a lady. Nobody's going to take you home to their mother if you're not a lady. I'm sorry. That's just the way it is. You know, and it takes time to be a lady.

Based on Jeffrey's purported goals for his female students, it does not matter if he is including women's perspectives if he is doing so in a way that undermines girls' intellectual advancement. For instance, if he is teaching his female students how to conform to an antiquated system of 
domesticity, then his inclusion does not positively impact female students in such a way that they would see their stories reflected in the content to feel as if they are not "worth less" than their male counterparts.

Based solely on this interview data, Jeffrey's teaching methodology does not necessarily fit into one of Tetreault's "Stages of Thinking about Women in History." In the example he provided about when he did include women's voices, he used only the textbook information, and did demonstrate an awareness of the roles of particular women within the unit. It appeared as though he simply "covered" the material that was presented in the book, without highlighting either the individual actors, or the social ramifications of each perspective included.

Jeffrey's refusal to allow me to observe him teach a lesson combined with his interview statements caused me to wonder if the refusal was, at least in part, because he did not have a lesson in which he thought he could present women's history authentically. Ultimately, Jeffery's resistance to participate further in the study does connect to this interview data, which demonstrates an air of male superiority. Perhaps also, Jeffrey's claim that he includes women's voices once a week was not entirely accurate. On the survey, the only perspective Jeffrey did not claim to include was that of the LGBT population due to time constraints. Thus, it is possible that Jeffrey claimed to incorporate more minority voices than he actually does in practice. This would account for his agreeing to participate in the study in order to discuss the inclusion of African-American perspectives and his disappointment that they study was in reality, about the inclusion of women's history. 


\section{Frank Reed}

Frank Reed is an eighth grade U.S. History teacher at a suburban middle school. He is a Caucasian male in his mid-forties, who received his master's degree in education. Frank grew up in a traditional, nuclear family. His father worked for the government and his mother was a homemaker. His family was quite religious, and Frank attended small Christian schools throughout his education. Frank stated that he experienced everything growing up, from a "WASP" (White-Anglo-Saxon-Protestant) viewpoint and only experienced other cultures and ideas once he reached high school. I interviewed Frank in his classroom before the start of school.

Frank began by discussing his motivation for including multiple perspectives in his lessons. He believes that students are more able to become independent learners when they face numerous perspectives on a given topic.

[I] do it for a number of reasons. One is to help the kids [learn] how to think critically. That's our ultimate goal - helping kids think for themselves and take information and digest it and come up with their own theories and ideas. So if we always present the White Anglo-Saxon Protestant view of everything, the kids will never learn to think critically. They get enough of that from the system beat down, you know...so we present other viewpoints and the kids will be able to learn to see things from different perspectives. I like to use the example, like if you're watching an accident scene, you're here, and you're here, and you're here, and you're over here, you're all seeing the same accident but from a different view point; and so we're all seeing things just a little bit differently. So, what do you see? Historically or from a historic perspective I'd like to say, when 
Columbus came over we idolized Columbus for how many centuries and said "what a great man he was" but when you look at from the perspective of the Hispanics and the islanders, he's not—but we made him out to be. We try to get the kids a look and see what somebody is from different angles.

From the outset, Frank exhibited an awareness of the need to incorporate multiple perspectives and the reasons he provided demonstrate his desire to teach his students how to be critical thinkers, how to look at a story within the text, question it, and approach from a different perspective. For his own lessons, Frank acknowledged the textbook's propensity to highlight the story of the white male, thus, he supplements his lessons by bringing in additional sources about other groups' experiences during the time under study.

Like when I do "Today in History", I often look for people or things that they wouldn't hear otherwise. If it doesn't fit directly with whatever our current topic of study is and I try to make sure I pull in, if possible something from either women's history or black or Hispanic history that they might not get otherwise.

Clearly, Frank demonstrated a motivation to diversify the content of his lessons even when the lesson did not easily lend itself to a multiplicity of perspectives.

Once I debriefed Frank on the actual topic of the study, he began to tell me about his upbringing and how it influenced his efforts to include women's history in his lessons. To Frank, women's perspectives are just one of the many voices he works to include. Like the most of the participants, Frank credited his inclusion of women to having a strong mother and what he described as an equal relationship between his parents.

My family comes from good strong Germans, my grandparents were of German descent and they ran the household accordingly—strict, very strict. And my dad 
taught me to respect everybody and especially to respect women and my mother expected nothing less and she got nothing less. My mother is a very strong woman and she raised us to respect everybody. The old, definitely the old fashion values of the father is the provider and mother raises the kids. My dad likes to say, "I'm the boss of this family. My wife gives me permission to say so;" [They're relationship was] very much equal. He was very concerned about how this would affect mom so he will always make sure that she had a 100\% buy in to whatever we did as a family. Mom always seem to present the attitude that he was the head of the household but, he still always had the attitude of "I may head of the household but my decision affects so many" and I heard her say in community a couple of years ago and this encapsulates my dad's philosophy of "happy wife, happy life" so he was going to make sure that whatever we did will be good with my mom, so [there was] definitely equality.

Frank also discussed how religion affected his family dynamic.

My parents were Lutheran by choice, Christian by baptism. My parents raised me in the church and I was very thankful to be in a church and as we moved to different places, being in church [there] was a top respect for people; and Jesus said "love one another as I loved you" and there were no conditions in that. So that's what my parents raised me to believe and raised our family to believe and how to treat other people. The spiritual influence is a really heavy on our family. Conservative but not fundamental and so as we got older and it was always interesting to see okay here's this Old Testament stuff, and Jacob had how many wives? And how many concubines? Oh my goodness, that just isn't right. My 
dad used to joke "I can't keep one woman happy, how could I handle all that many women?" But the spiritual influence is a real heavy influence even for me today, it still is. I just have to make sure that, for me the bible says I'm supposed to be the head of the house, but like my father who set a good example for me, my wife's opinion and her well being, and happiness, is first for me, and so that influences how I live my life and be the "head of the house."

Frank's religious beliefs clearly affect his home life, and how he views gender roles. Though he believes that the male should be the "head of the house", he balances that with his efforts to establish equality between husband and wife. His wife works outside the home, in a high profile position in the church.

When it came to his own schooling, Frank did not remember learning much about women's contributions in history.

It was traditional history-Columbus came over, we had the Civil War and waged all the wars and everything, I think our teacher liked war; maybe that's where I got it from. But in terms of specifically looking at women and their role and their place and their contributions in history, I don't remember that we did a lot of that. I can't say from the textbook what was or wasn't there. The one that sticks out the most is Rosa Parks and that may have been because that was still so fresh. I recall Queen Isabella of Spain and Ramsey's wife but there wasn't a real focus on the contributions that they made. [About the Suffrage Movement I learned] only in terms of the amendment for women's right to vote. There wasn't a lot of it... Susan B. Anthony we got that, but there wasn't much beyond that. 
Despite his efforts to include social history in his own class, Frank admits to being partial to military history and attributes that focus to teachers emphasizing wars during his own education. In contrast, his efforts to include social history do not stem from an exposure to such issues during his own schooling.

For his own teaching, Frank says the greatest challenge when bringing in women's perspectives comes from the paltry coverage in the textbook.

Probably the biggest difficulty will be trying to make sure you find women, because, again in the textbook, they might have a token biography of somebody and it seems that they try and rotate it around here's an African American, here's a woman, here's a Hispanic so it may be one per chapter. It's not very good so trying to find, even as I looked into today's activity, I went through a couple of resources and looking for significant women or famous American women in the 1800s to 1850s and I come across this website and ended up putting some of these in. But I don't know, - probably the biggest difficulty is finding resources.

Frank says he usually follows the sequence of instruction as laid out by the district's instructional plan, and the textbook chronology, so when he adds in the perspectives of minorities, he has to find resources outside of the resources provided by the school. When asked why he makes the effort to find such resources Franks said,

I look at what they say is important, but it's also important to bring in the inclusion of other cultures and genders. So I try to make sure that all the kids are having the opportunity to learn and be inspired.

Frank attempts to bring in women's stories that are not normally included in the textbook. Though some of the women he mentioned included Abigail Adams, Clara Barton, Harriet 
Beecher Stowe, Martha Washington, and Harriet Tubman-worthwhile to include, however, they are the women usually included in a traditional American history class-wives of powerful men and "first" accomplishers.

An example Frank provided, explaining how he typically goes about including women's perspectives consisted of a group of students exploring an individual's biography and sharing with the class.

There's generally four people in the group, some groups have three but for the most part each person has a job. One will be the group leader, one will be the timekeeper, one will be the reader and one will be the recorder, but they all contribute to the answers. Let's say they picked Clara Barton, so one person is going to read [the biography] to the group and they'll have the questions [on the board] at the back of their mind while they're hearing this. Then they will answer those questions - who was the person? Why is she significant? Would people view her as a hero or a villain? Who might view her as a hero or a villain? Why? That kind of stuff, they get to take a very brief and quick look at that person and then after a short time of study they'll come back and present it to everybody what they learned, what the group has learned.

Such a lesson illustrates the value Frank places on teaching the student rather than teaching the content. He employs the pedagogical best practices of cooperative learning, Document Based Questions (DBQ's), technology enhanced lectures, role-playing, historical reenactments, and the utilization of primary and secondary sources. Moreover, Frank teaches students to inspire them, to instill a love of history, or a personal connection to a figure from the past. 
For his female students, Frank says he wants to empower them to be able to reach any goal they set for themselves.

I want the kids, through this course, to be able to walk out of here saying, "I can be whatever I want to be. Other people have obstacles and they overcame them. Whatever my obstacle is, I'm still learning English or perceived that I'm a female and that's an obstacle." I don't want that to be an obstacle for anybody, and so I try and help the kids say, "you can be whatever you want to be." I probably encourage the girls more because I see a lot of self-image issues and so if anything I try and encourage them more. There's a lot of smart girls in there, but it's almost like they're afraid to show they're smart. I try to help them learn that if they don't fall down once a while, they won't know how to get up, and if you don't fall down once a while, it means you're not walking forward.

Frank's history class is about not only learning the content, but also learning to set and achieve goals. Though perhaps attributable to the middle school setting, however, Frank, through his interview and his classroom décor, emblemized the setting and achieving of goals. A handmade banner hung above his whiteboard, it read: "Think little goals and expect little achievements. Think BIG goals and win BIG SUCCESS!" This is the message he conveyed to all of his students. This motto reflects Frank's desire to meet students where they are, and help them achieve the big goals.

When asked how his inclusion of women's voices affects his class, Frank said that the girls "perk up" when they hear about a female in an activity.

Otherwise it would be like, “oh we're studying war again," but I've not done any measurement to find out. As much as I'd like just to have this year be that year, 
that this is the life-changing year, I realize that realistically it's one of the many years. It's a building block, a stone in the house but if I don't put that stone in, then it's going to be missing. If I'm talking about Robert E. Lee or Ulysses Grant, the girls are sitting there going "another general" but if I talk about Clara Barton and her influence and contributions in the civil war and it's not just that because it's a woman they become inspired, but I think it opens their eyes more to what else is out there, if you will. I think it's important to recognize all the contributions that men and woman both have made to the greatness of this country, to our world.

Despite the fact that Frank knows he is only one teacher in his students' lives, he values the role he plays and the influence he has the potential to hold. He sets out to make his students aware of a multiplicity of contributions from a diverse population.

Irrespective of all Frank does to inspire his female students to set and achieve high goals, he does not deem himself a feminist. He said the word alone had a "horrible connotation" and when asked if he considered himself a feminist he said, "No, oh heavens no. I'm fully into women's rights, equality, but I wouldn't call myself a feminist." Frank's distaste for the term may stem from his political beliefs. While his actions in the classroom demonstrate his desire to foster equality, politically he considers himself a conservative Republican - against reproductive choice and marriage equality. Despite his articulated personal political perspective, his beliefs do not appear to affect the message he sends to his female students regarding his hopes for their bright futures. 


\section{Classroom Observation}

I arrived to Mr. Reed's classroom before the beginning of school. Already the lesson was on the board and the Prometheus screen had directions for students' bellwork: "Write in binder1861 President Jefferson Davis of the Confederacy signs a bill declaring war between the Confederacy and the US."

The board read: "Notes for DVD. What were the traditional and non-traditional roles of women? And, What hardships did women face that men did not?" Additionally, the Learning Goal for the day was on the board: "Students will be able to identify and analyze contributions of men and women in the development in the U.S."

As students began arriving, they picked up their binders from the counter and were instructed to complete their bellwork. While students were working, classical music played in the background. The students spoke to one another, engaging in some side conversations while Mr. Reed took attendance.

Mr. Reed: Happy Monday! You realize there are only four Mondays left before the end of the year?

After addressing some small talk with the students, Mr. Reed read the bellwork and the events from "Today in History" aloud to the class:

1833 John Deere makes first steel plow

1914 British Parliament rejects women's suffrage

1960 President Eisenhower signs the Civil Rights Act of 1960

Mr. Reed introduced me to the class, and then drew students' attention to the Learning Goal and agenda for the day. 
Student:

Mr. Reed:

How was your Cinco de Mayo?

Great! Just like every other Cinco de Mayo, I spent it at church with my family.

Following the learning goal, Mr. Reed reviewed the Marzano learning scale; most students indicate they are at level 2 or 3 on the Learning Goal.

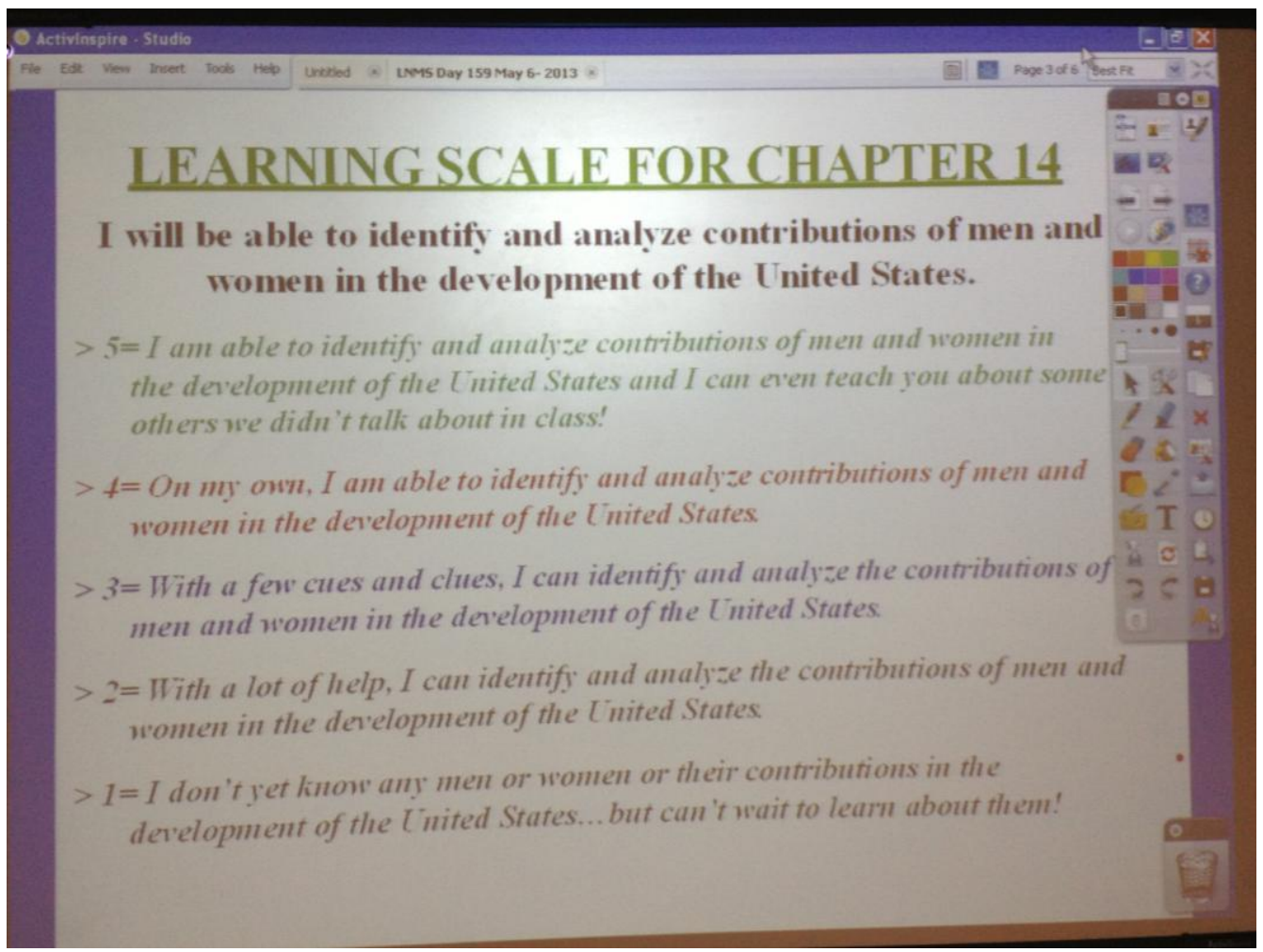

Figure 9: Reed's Marzano Scale 
On the board, Mr. Reed drew a T-Chart

Table 8: Mr. Reed's T-Chart

\begin{tabular}{|c|c|c|c|}
\hline $\begin{array}{l}\text { Gender } \\
\text { of } \\
\text { student }\end{array}$ & Women's Roles in the 1800's & $\begin{array}{l}\text { Gender } \\
\text { of } \\
\text { student }\end{array}$ & $\begin{array}{l}\text { How did women participate in the Civil } \\
\text { War? }\end{array}$ \\
\hline $\mathrm{F}$ & They had to take care of the kids & M & Nurses \\
\hline $\mathrm{F}$ & They had to do chores & $\mathrm{M}$ & Keep house at home \\
\hline $\mathrm{M}$ & Some were doctors in the field & $\mathrm{F}$ & $\begin{array}{l}\text { Cooks (stolen answer from male } \\
\text { student seating next to her) }\end{array}$ \\
\hline $\mathrm{F}$ & Wear corsets & $\mathrm{F}$ & $\begin{array}{l}\text { I remember one thing: they would } \\
\text { actually fight in the war taking the } \\
\text { place of some men }\end{array}$ \\
\hline M & Cook & $\mathrm{F}$ & They had to do stuff with dead bodies \\
\hline M & $\begin{array}{l}\text { Had to make a good impression, } \\
\text { have good manners, be a good wife }\end{array}$ & M & Giving support/motivation \\
\hline $\bar{F}$ & $\begin{array}{l}\text { They never had to work or do hard } \\
\text { labor, that was the husbands job }\end{array}$ & $\mathrm{M}$ & $\begin{array}{l}\text { Move to next battlefield, follow the } \\
\text { camps }\end{array}$ \\
\hline $\mathrm{M}$ & They did work IN the house & M & Raise horses \\
\hline M & They had gender specific jobs & & \\
\hline
\end{tabular}

After brainstorming what students knew, or thought they knew about women's roles in the Civil War, Mr. Reed directed students to take notes on a film about Sarah Edmonds, a female soldier in the Civil War. He told them to specifically look for the traditional and non-traditional roles of women, and the hardship women faced, that men did not.

The movie Full Metal Corset: Secret Soldiers of the Civil War was a documentary from the History Channel, for which a number of historians were interviewed, all female. The film described how women have been traditionally excluded from combat, "Women were denied the right to defend their country." Because of that, hundreds of women disguised themselves as men to fight. The story Mr. Reed played from the video was that of Sarah Edmunds, who, according to the documentary, ran away from home rather than being married off as a 15 year-old to an older man. She faced many challenges as an independent woman, so at the age of 17, she 
changed her identity and transformed herself into a man, binding her chest, learning to walk like a man, and taking to smoking, drinking and spitting. After a couple of years of selling bibles, Edmonds enlisted as a Union soldier and became a nurse in the army. At that time, nursing was a man's profession because women could not touch strange bodies. She also had to fight on the battlefield. It was noted in the documentary that the stories of hundreds, or thousands of women who disguised themselves as men to fight in the Civil War, were left out of the history books. (Unknown, 2007).

After watching the video, Mr. Reed had students list their observations according to the notes they took.

Table 9: Student Responses to Roles and Hardships of Women

\begin{tabular}{l|l}
$\begin{array}{l}\text { Gender of } \\
\text { student } \\
\text { M }\end{array}$ & Traditional \& Non-Traditional Roles for Women \\
\hline I & Weren't allowed to be nurses \\
\hline F & Weren't allowed to touch bodies \\
\hline M & Weren't allowed to fight in the war at all \\
\hline F & They could get water and stuff \\
\hline & What kind of hardships did women have that men did not? \\
\hline F & Very little freedom \\
\hline M & Always had to have a male escort \\
\hline F & Father could have the an arranged marriage \\
\hline M & Some women took the risk and changed their identity \\
\hline Teacher & No political choices \\
\hline
\end{tabular}


Following the discussion of the film, Mr. Reed provided directions for the activity.

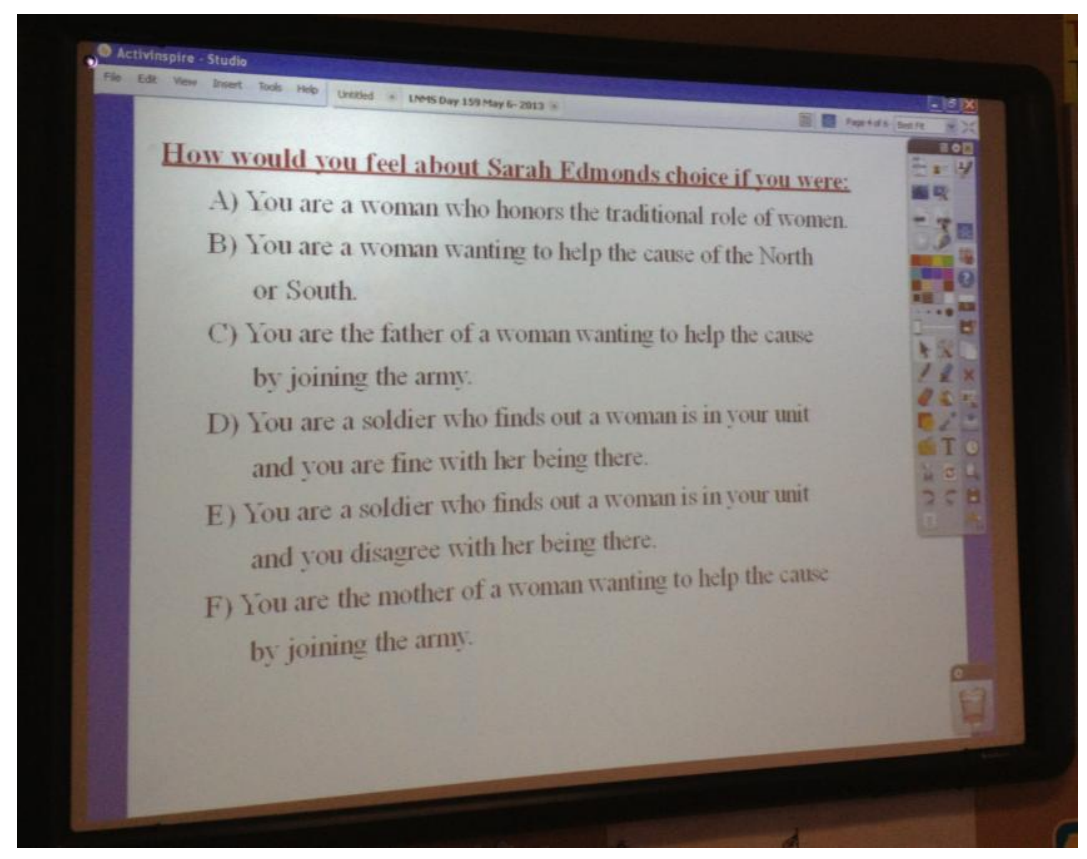

Figure 10: Directions for Group Work in Mr. Reed's Class

Students were assigned a group to explain how they would feel about Sarah Edmonds disguising herself as a man and joining the army. 
Table 10: Group Work Responses Mr. Reed's Class

\begin{tabular}{|l|l|}
\hline Assigned Role & Feeling from group \\
\hline $\begin{array}{l}\text { A woman who honors the traditional role } \\
\text { of women }\end{array}$ & $\begin{array}{l}\text { We disapprove of what she is doing. She } \\
\text { should listen to her father, stay home, and } \\
\text { not break the law. }\end{array}$ \\
\hline $\begin{array}{l}\text { A woman trying to help the cause of the } \\
\text { North or South. }\end{array}$ & $\begin{array}{l}\text { We would join her so she wouldn't fight } \\
\text { alone. }\end{array}$ \\
Mr. Reed: 'So she inspired you to join up, \\
I didn't think of that."
\end{tabular}

After students shared their group determinations, the class ended and students were dismissed.

This lesson specifically examined the life of a woman who is not traditionally covered in a Civil War unit. Students examined traditional gender roles and the challenges women faced as non-equal members of society. During the discussion of the documentary, one student said, "some women took the risk and changed their identity." Mr. Reed's response was, "yes, she changed her identity to fight in the war." This was not accurate according to the film and presented a missed opportunity for Mr. Reed to discuss Sarah Edmond's true motivations for disguising her gender.

Nevertheless, as per this lesson, Mr. Reed's inclusion of women in history encapsulated the Compensatory stage in Tetreault's "Stages of Thinking about Women in History (Tetreault, 
1986a). This is the first stage after "Male History" in which the absence of females is not noted. In the Compensatory stage, "the absence of women is noted. There is a search for missing women according to a male norm of greatness, excellence of humanness. Women are considered as exceptional, deviant or 'other." Accordingly, for this lesson, Mr. Reed's students examined the life a "deviant" woman, who was literally measured according the "male norm of greatness," hiding her own identity in order to serve in the military as a man in disguise.

Mr. Reed's lesson did bring women's voices to the traditionally male dominated content. His self-expressed goal of wanting to inspire students to achieve great things could be met by this lesson. However, this lesson focused on a woman who rejected gender roles; thus, attention was not on a broad female experience, or on social history, rather, it fell on the way in which a woman was able to live up to the male standard of accomplishment. This has the potential to illustrate to female students that their value can be ascertained by measuring how well they can assimilate to the norms of male culture. While I do not believe that this was necessarily the objective set forth by Mr. Reed, or other teachers, it nevertheless requires examination when discussing a gender inclusive curriculum.

\section{Conclusion of Findings}

These interviews and observations aimed to answer the questions of how and why some teachers include women's voices in their classes. The participants had a variety of responses thus, not a single unifying motivation was identified. A discussion of how each participant includes women's history/perspectives is detailed in Chapter 5. 


\section{CHAPTER 5: CONCLUSIONS AND IMPLICATIONS}

The inclusion of women's history in the traditional social studies classroom is as varied and complex as the individuals who agreed to participate in this study. The purpose was to garner an understanding of why teachers took the trouble to include women's voices in their curriculum when it was not required by the educational standards. In approaching this study, I believed that I would find commonalities in individuals who made such an effort, and to some extent such commonalities were indeed found; however, there was no overarching belief system that united the participants, no common goal, and no deep understanding or appreciation of women's history as a whole.

The themes that emerged from the interviews tended to have more to do with the topic of discussion, rather than a common participant experience. Thus, other than the fact that all but one of the participants had a military background, I found that each of them came to the teaching profession from diverse backgrounds, with a variety of beliefs, and a multiplicity of objectives.

\section{Initial Findings}

The survey provided demographic information as well as data concerning the inclusion of women's history. It is worth noting that $57.1 \%$ of valid respondents were female, however, of those who elected to participate further in the study, only one was female. I believe this is due to the fact that the survey was purposefully misleading; in asking about the inclusion of a variety of multiple perspectives rather than simply women's perspectives, potential participants had no clear understanding of what, exactly, would be observed. I believe I would have had a different demographic turnout if the subject of the study were clearer on the survey.

Another interesting initial finding came in the early part of the interview data. Due to my misleading participants on the survey, by titling it The Inclusion of Multiple Perspectives in the 
Secondary Social Studies Classroom, each participant assumed the study was in reality, regarding the inclusion of African-American perspectives. This came up in the interviews with Mark Webb, Aaron Branch, and Jeffrey Emerson. Fortunately, it became problematic with only one participant, Mr. Emerson - who upon reflection decided to participant no further than the interview.

\section{Research Questions}

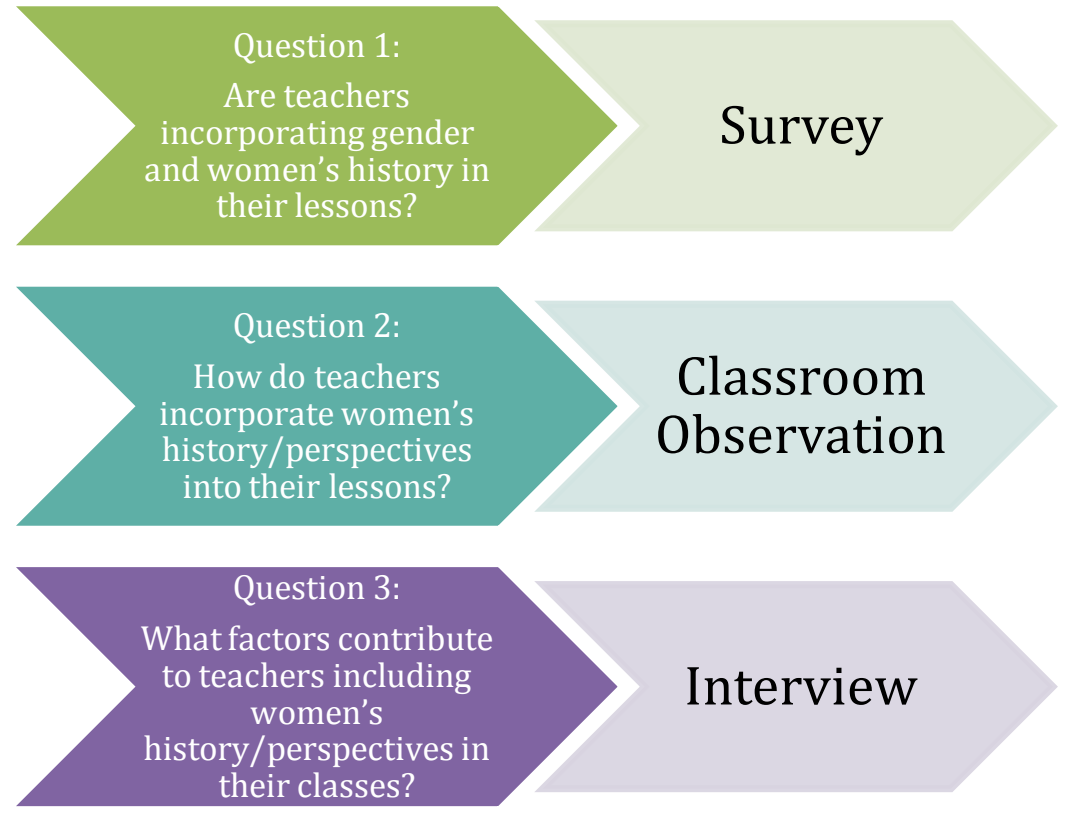

Figure 11: Research Question/Data Form

\section{Question 1: Are teachers incorporating gender and women's history in their lessons?}

In order to answer question one: Are teachers incorporating gender and women's history in their lessons? I implemented the survey to ascertain how many teachers claimed to do so. The results indicated that an overwhelming majority of secondary social studies teachers, $91.4 \%$, did indeed incorporate women's voices into their lessons. Yet, only $12.5 \%$ claimed to include women's perspectives more than once a week. Ultimately, while the question can be answered in the affirmative, teachers are including women's voices in their lessons, only a small 
percentage does so on a regular basis, and it remains unknown what those lessons include and where they fall on the continuum of inclusion.

While large majorities of teachers claim to include women's voices in their lessons, they may be doing so in such a manner that perpetuates oppressive systems and does not highlight the contributions women have made to society. Thus if the lessons of inclusion are based on the Compensatory History stage, then women are added to the traditional content only if they can be measured "according to the male norm of greatness" and not through a holistic view of human experience (Tetreault, 1986a).

\section{Question 2: How do teachers incorporate women's history/perspectives into the}

\section{lesson?}

In order to answer my second question, How do teachers incorporate women's history/perspectives into the lesson? I observed five teachers in their classrooms. This observation followed our interview; hence, participants were aware of the study's topic and for the most part planned and taught lessons that, in their view, met the goals of the study. Interestingly, two participants, Aaron Branch and Ned Hudson planned lessons on specific women's issues, The Equal Rights Amendment and the Women's Movement of the 1970's, respectively. The topics in those cases affected where each teacher fell according to Tetreault's "Stages of Thinking about Women in History." Whereas Aaron Branch's lesson about the ERA was under the Bi-Focal History stage, Ned Hudson's lesson on the Women's Movement actually fit under the Feminist History stage. Interestingly, the interview data and observational data did not always match. This could be the result of the fact that some participants may have told me what they thought I wanted to hear in the interview, but did not, in actuality, perform in such a manner in their own classrooms. 
Understanding how teachers incorporated women's history was best explored through finding where each participant appeared on Tetreault's continuum.

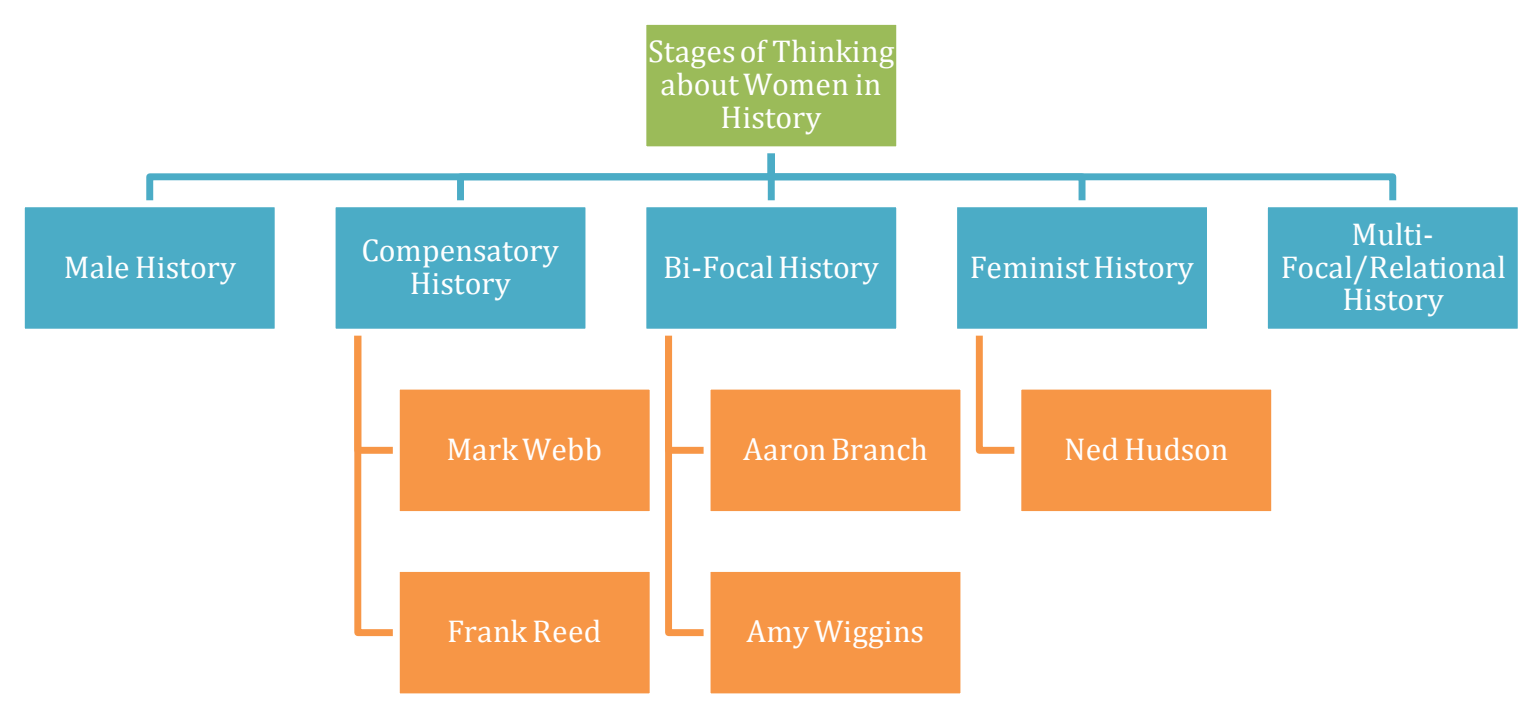

Figure 12: Participant's Stages of Including Women's History (Lesson Based)

For the purpose of this study, I examined the content presented, the dialog between teacher and student, and the resources utilized by the teachers. I did not critically examine the methodologies employed by each teacher pertaining to whether they implemented best pedagogical practices, and only mentioned it in the findings when it was pertinent to the overall purpose.

While I did not critically examine the pedagogical methods, it is worth discussing the variety of approaches used by participants to incorporate women's history/perspectives. It appeared likely that Mark Webb and Amy Wiggins were the only teachers to stick with their previously planned lessons, allowing me to see how they authentically include women's history into their curriculum. While Webb conducted an Advanced Placement test review scavenger 
hunt, his inclusion of women's history was based on pointing out to students the challenge of being able to name female psychologists in comparison the ease of naming a number of male psychologists. Wiggins on the other hand, demonstrated her approach to including women by acknowledging that it was the textbook that included women's history, her lesson magnified the inclusion by drawing students' attention to the section on women's history and having them complete a foldable, one section being dedicated to women's history.

Documentary films similarly provided teachers a way to include women's perspectives. Both Aaron Branch and Frank Reed implemented documentaries to allow the experts (the historians interviewed for the film) to better explain the content included. The documentary used by Branch focused on the history of the ERA, while the one shown by Reed told the story of a female Civil War veteran and her disguising herself as man during her enlistment. Notably, Branch's lesson focused solely on an issue pertaining to women's history, whereas Reed's lesson incorporated a female perspective into a traditionally male oriented topic, the American Civil War.

The discussion that followed the video in Reed's class also provided insight into the manner in which women's perspectives are included. The video itself pointed out the way in which women's activities in the public sphere are acceptable when they either champion male activities (as was the case with Sarah Edmonds, subject of the documentary) or are a broadening of women's supporting role within the family. This reinforces the idea that women's virtue lies in self-sacrifice. During the discussion activity following the video, one female student remarked that if she was the mother of a daughter during the Civil War, who wanted to fight disguised as a man, she would support her through anything, because that is what a mother does. As Tetreault pointed out, adolescent females struggle with the ethic of self-sacrifice in contrast to 
the concept of their own rights (Tetreault, 1986b). However, these issues were not explored in the discussion.

Teachers also used lectures to disseminate information to students. Ned Hudson was the only participant in this study to fully employ a lecture, however, his oration was supplemented with a PowerPoint presentation, using graphs, charts, images, and video clips. While his students were not engaged in any sort of critical thinking, they were exposed to the highest level of inclusion along Tetreault's "Stages of Thinking about Women in History" in this study.

When it came to matters of gender bias, the five participants I observed were cognizant of the issues. Gollnick, Sadker and Sadker identified six types of gender bias in both textbooks and in the classroom (Gollnick et al., 1982, p. 94). These include:

1) Invisibility or underrepresentation

2) Stereotyping

3) Selectivity and imbalance (focus on aspects of history such as political and military that have little female presence)

4) Unreality in instructional material (spotless housewife)

5) Fragmentation and isolation (marginalization)

6) Linguistic bias: caveman, mankind, forefathers etc. (Gollnick et al., 1982). These participants acknowledged the invisibility and underrepresentation of women in the curriculum, thus made efforts to overcome those issues by adding more women's perspectives into their lessons. A number of the participants intentionally addressed issues of stereotyping, for instance, Reed asked his students to consider historic gender roles and challenges women faced that men did not. When it came to issues of selectivity and imbalance, most participants intentionally chose topics that were based on social history rather than military or political 
history. Marginalization, however, remained an issue, particularly in Webb's class - when the focus of his inclusion relied on simply pointing out to students a paucity of awareness of female psychologists that existed in their content knowledge. Finally, linguistic bias, as defined by Gollnick, Sadker and Sadker, did not appear in the lessons I observed.

\section{Question 3: What factors contribute to teachers including women's}

\section{history/perspectives in their classes?}

To answer the third question: What factors contribute to teachers including women's history/perspectives in their classes? I interviewed each participant. Before the interview, teachers were not aware of the true nature of the study. In order to reduce bias from the survey results, I intentionally misled participants in the title of the study. By asking about their inclusion of multiple perspectives, the participants who agreed to contribute further in the study, did make efforts to include a variety of multiple perspectives, but none had a strong connection to the importance of including women's history specifically. Based on the interview data, a singular motivation for why teachers go "above and beyond" to include women's history was not apparent.

From six interviews, I was able to identify four overarching themes based on the sections of the interview (Early life/background, Beliefs, Ideas of Self, and Classroom Practices) with 26 subthemes. The most common themes related to participants' upbringing; many of them came from families with at least one parent in the military. Additionally, nearly of the participants attributed their efforts to include women in the curriculum to having "a strong mother." Moreover, multiple participants mentioned their observation of female students "perking up" when they included women's perspectives in their lessons. 
Additionally, participants' families influenced how they approached an inclusive curriculum. Frank Reed noted his desire to inspire young women the way he hopes his own daughter would be inspired by her teachers. Ned Hudson discussed his efforts to teach his male students how to take care of themselves and not rely on the women in their lives to do the housework. Each participant discussed their own familial relationships during their childhoods, Mark Webb indicated that seeing his own father act in a chauvinistic manner inspired his to act in an opposite direction. From this information, it is apparent that a teacher's home life, upbringing, and belief systems correlate strongly with their classroom behavior.

Participants' expressed opinions on issues pertaining to the idea of feminism were surprising to me. While only two contributors, Branch and Webb, accepted the label without qualification, the rest of the participants could not agree to call themselves feminists, even after the definition provided coincided with their beliefs about including women in their interview. In one such case, after supplying the definition of feminism as "the belief that men and women are equal," Jeffrey Emerson indicated that while he believes that to be true, he nonetheless could not self-identify as a feminist. His reason was that, in his opinion, "feminists believe everyone who does not agree with them are evil and are going to hell." Ned Hudson equated the word with lesbianism, and while in the end he did acknowledge that he taught in a feminist nature, he still "had a difficult time digesting" the word, and brought it up again during his classroom observation. This was surprising to me because I believed that teachers who took efforts to include women's history/perspectives would not have negative associations with the terminology of feminism.

Additionally, participants' individual views on reproductive rights did not appear to affect their overall thoughts and beliefs about women's roles and reasons for inclusion of 
women's perspectives in the curriculum. For instance, Emerson spoke adamantly about his belief in reproductive choice and freedom, however, much of what he said about his thoughts on women's roles, their importance to the family, being the center of the home, importance of "being a lady," the difference between a "nasty lady" and a "lady lady" had intensely paternalistic overtones. Whereas, Reed, on the other hand, was not in favor of reproductive choice for women, yet he spoke of inspiring his female students to not be limited in any capacity. Though his lesson did not reach an advanced stage of including women in history, he did take efforts to have students think critically about the roles of women in the past and provided a number of examples on how he brought women's history/perspectives into his lessons though a variety of methods.

Though some teachers had ideologies that were reflective of their desire to include female perspectives, others, like Amy Wiggins, did not. For Wiggins, the motivation for including women essentially stemmed from the course requirements and what was included in the textbook. Her efforts to include women were not rooted in any internal belief that women had not been included in the past, nor that their stories were particularly important. At best, Wiggins acknowledgment that the inclusion of women's history "was getting better" and that she included it because her students asked about it, was the most she could offer on the her motivations for inclusion. Consequently, as Hahn pointed out, if gender equity was prevalent in social studies classrooms, "the histories, narratives, and lived experience of boys and girls, men and women, would be represented equally and accurately in social studies textbooks, supplemental curricular materials and classroom instruction" (Hahn et al., 2007). In Wiggins's case, she utilized the textbook to draw in the female experience. However, in the chapter she highlighted, women represented only one-fourth of the content for the day; thus, while the 
content may have been accurate, it was not equally representative of the female and male experience.

\section{Implications}

This study illuminates both the reasons why some teachers include women's perspectives, and, in a limited manner, how they do so. Though no overarching conclusion can be drawn as to a central motivation for including women's history, from this study we can see that some teachers include women's history because it is required for their content, it is in their textbook, they believe areas of women's history (ERA, the Women's Movement) should be included in the traditional curriculum, or they believe that the absence of women should be pointed out to their students. From this information we can deduce that, at least for the participants in this study, that nowhere in their lives was a strong importance placed on including women's history.

The findings shed light on how teacher educators can better prepare future teachers to understand their own perceptions of gender equity, and how to address issues of gender equity in their social studies classes in the future. From the information obtained from participants, it was not apparent that they received such instruction in their own schooling, neither within the context of their content courses nor in their teacher education courses. Thus, teacher educators have the potential to address issues of gender equity within the social studies context, making explicit the necessity for teachers to consider the including women's perspectives and interweave them throughout their content.

This study additionally provides information on current classroom practices that address gender equity concerns. Currently, teachers who incorporate women's perspectives do so predominately in the middle-low end of Tetreault's continuum. If incorporating women's 
perspectives and women's history was made a priority in teacher education then perhaps current classroom practices would reflect a higher level of inclusion, both in the amount of inclusion and in the "Stages of Thinking About Women in History."

Gender equity must be addressed in teacher education in order to foster teacher candidates' desire to include women's history in social studies classes. Teacher education programs that include gender equity training may include curriculum that instructs teacher candidates how to incorporate women's history and perspectives at the higher end of the "Stages of Thinking About Women in History." Thus, there is a need for pre-service teachers to understand the stages of inclusion so that they are able to incorporate women's history at the higher end of Tetreault's continuum. This will allow for opportunities for teacher candidates to consider ideas of gender equity while in a teacher education program.

Moreover, teachers could implement the suggestions from Clio in the Classroom: A Guide for Teaching U. S. Women's History which as described in Chapter 2, provides a handbooks with key content, concepts and teaching strategies that "move beyond the notion of women's history as a compendium of 'firsts'," (Berkin et al., 2009, p. 3). Included are strategies for redesigning history courses to implement a focus on feminist pedagogy, and social studies best practices.

Furthermore, classroom teachers can implement the strategies outlined in the Handbook for Achieving Gender Equity through Education; in which the authors recommend social studies teachers:

- Ensure that substantial attention is devoted to gender in curriculum in order to present an accurate view of gendered human experience in history and contemporary society; 
- Social studies curriculum developers give more attention to the diverse experience of women and girls by class, race, ethnicity and sexual orientation;

- The notion of gender equity be expanded to include all individuals; men and boys are gendered as well as women and girls;

- Connections between universities and colleges and K-12 social studies educators be strengthened to support curriculum transformation based on new knowledge;

- Policy makers, practioners, and scholars address the need to look at structural problems in school systems and classrooms that create barriers to delivering gender-equitable social studies; and

- Continue research along several lines of inquiry — including among others — the benefits of gender inclusion in social studies in the elementary grades, gender and technology, and teacher and classroom practices (Hahn et al., 2007).

Additionally, if teachers can employ Feminist teaching practices such as "empowering students, decentering authority in the classroom, creating cohesive learning communities, and honoring students' diverse experiences" they have a better chance of fostering a gender balanced curriculum and equitable classroom environment (Goldberg, 2009, p. 210).

\section{Limitations}

There are several limitations to this study. First, the participants were selected from the southeastern region, thus the data and conclusions will have a regional, rather than national perspective. Additionally, this study only addressed secondary social studies teachers who incorporate women's history/perspectives into their curriculum. This concentration denied the contributions of elementary teachers who promote gender equity in their classes. Furthermore, this study did not look at the inclusion of sexuality issues nor of the presence of other multiple 
perspectives such as race, class, or ethnicity. Additionally, this study did not address the construction of male identities or theories of masculinity. In regards to the study design, since the lessons observed were planned, it is not clear how participants incorporate women's perspective on a weekly basis, when the content is not focused explicitly on the female experience, or when they do not have the opportunity to plan when they are being observed. Finally, since this study took on a phenomenological approach, it is not generalizable to a larger population.

Another limitation of this study is the fact that current curriculum standards do not include a large number of standards on women's contributions to society, thus teachers who do include women's history run the risk of losing their jobs if they veer too far away from they required content standards. This may have impacted, and limited, the participants available for this study.

\section{Suggestions for Future Research}

There are a number of possibilities for future research related to the findings from this study. First, it would be interesting to see how students in participants' classrooms perceive the lessons which include women's voices and how the students are affected by such lessons over a period of time. Second, a similar study examining how sexuality is addressed in social studies classrooms would be beneficial. Third, a study that examines how teachers incorporate a variety of multiple perspectives including race, class, gender, sexuality, and how often each of these perspectives is addressed in comparison to the others and in comparison to the traditional social studies/history framework might complete the picture of why and how social studies teacher address multiple perspectives. 
Additionally, some of the drawbacks of phenomenological case studies are that they are not generalizable to greater populations. However, a future study could develop a survey from themes found within this study for large-scale dissemination and factor analysis. Moreover, an interview-based study that is not preempted by a survey might show different results since in this study, interview participants could easily have been guided by survey questions.

\section{Concluding Thoughts}

Based on this study, it appears that teachers who strive to include multiple perspectives in their lessons, whether they be women's perspectives, or those of a variety of minority populations, for the most part, do so because they because they have a strong capacity for empathy. The majority of participants in this study did indeed express such an aptitude.

I believe that of the participants I had for this study, none of them fit the description of they type of teacher I intended to include. None of them categorically went "above and beyond" the requirements, they may have done so here and there, but overall, it was not apparent that a conscious effort was made to specifically include women's voices in their already full curriculum.

It was challenging to allow for participants compartmentalization of ideas, from their interview discussions to their classroom observations. According to Stewart's (1994) Feminist Research Strategies, avoiding looking for a coherent self or voice is critical. Most of the participants did not have a coherent self or voice, fortunately, by following Stewart's principles I was able to allow for disjointed and unharmonious data.

Perhaps one reason participants did not overall find themselves on the higher end of Tetreault's continuum, was their lack of content background, "Teachers whose own education has emphasized these traditional perspectives are often reluctant to address topics from social 
and women's history with which they are not familiar" (Crocco, 1997, p. 32). As Gollnick, Sadker, and Sadker pointed out, most students leave school only knowing a few facts about women's history:

Women arrived in 1619. They held the Seneca Falls Convention on Women's Rights in 1848. During the rest of the nineteenth century, they participated in reform movements, chiefly temperance, and were exploited in factories. In 1920 they were given the vote. They joined the armed forces during the Second World War and thereafter have enjoyed the good life in America (Gollnick et al., 1982) Thus, teachers whose knowledge of women's history encompasses only those few facts cannot engage their students in deep understanding of women's contributions to society. While I generally applaud the efforts of the participants in this study to include women in their lessons, much work needs to be done to increase the awareness and importance of including women's history, voices, and perspectives. 
APPENDIX A: SURVEY 
Part I

\begin{tabular}{|c|cl|}
\hline 1 & $\begin{array}{l}\text { Please indicate if you regularly include the below minority viewpoints } \\
\text { in your history lessons. }\end{array}$ \\
\hline & $\square$ & African-Americans \\
& $\square$ & Women \\
& $\square$ & Latinos/as \\
& $\square$ & Gay/Lesbian \\
& $\square$ & Asian \\
& $\square$ & Native American \\
& $\square$ & Religious Minorities \\
& & Other: \\
& & \\
&
\end{tabular}

\section{Part II}

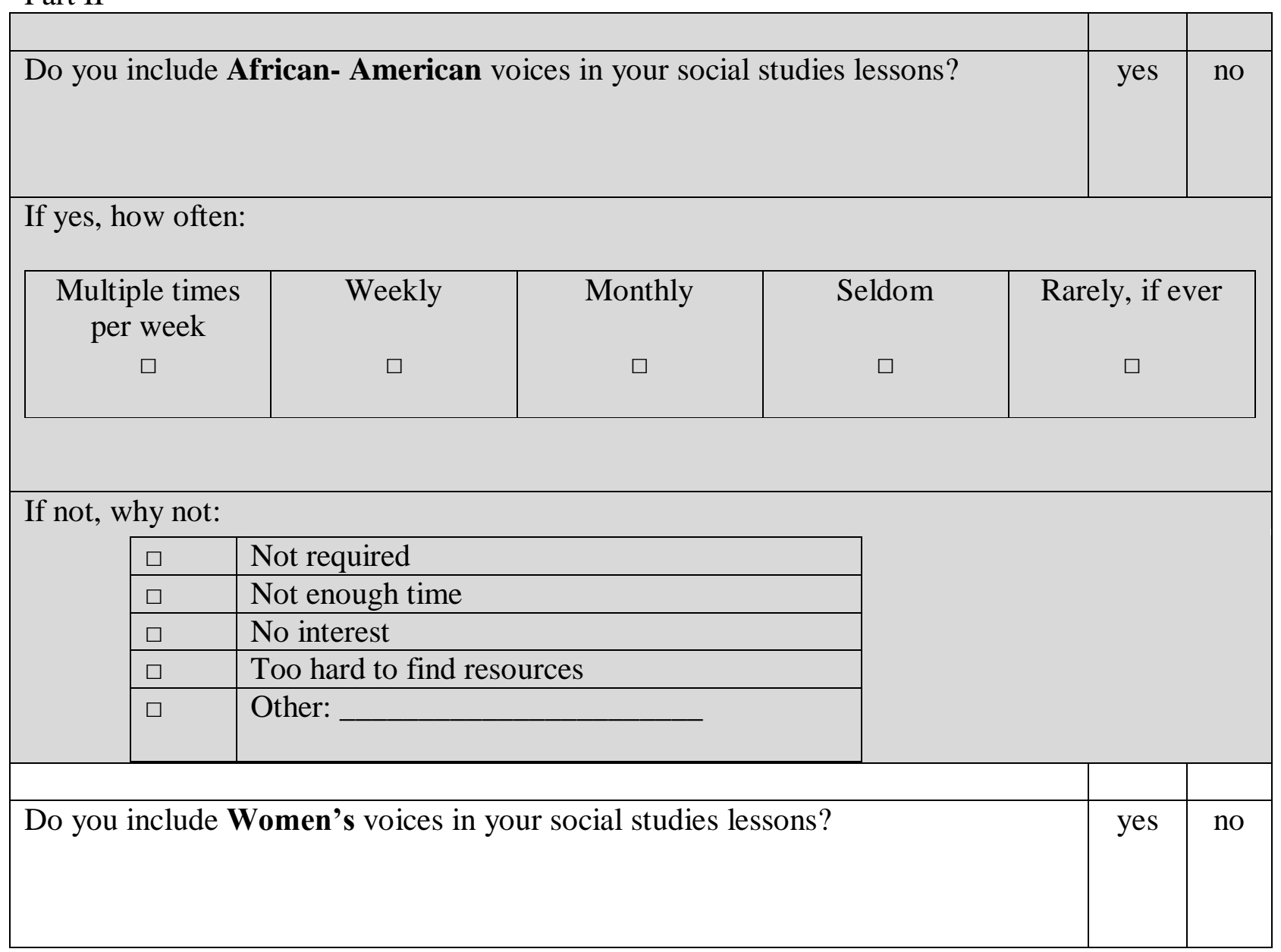




\begin{tabular}{|c|c|c|c|c|c|}
\hline \multicolumn{6}{|l|}{ If yes, how often: } \\
\hline $\begin{array}{l}\text { Multiple times } \\
\text { per week } \\
\square\end{array}$ & $\begin{array}{c}\text { Weekly } \\
\square\end{array}$ & $\begin{array}{c}\text { Monthly } \\
\square\end{array}$ & $\begin{array}{c}\text { Seldom } \\
\square\end{array}$ & \multicolumn{2}{|c|}{$\begin{array}{c}\text { Rarely, if ever } \\
\square\end{array}$} \\
\hline \multicolumn{6}{|l|}{ If not, why not: } \\
\hline$\square$ & \multicolumn{3}{|l|}{ Not required } & & \\
\hline$\square$ & \multicolumn{3}{|l|}{ Not enough time } & & \\
\hline$\square$ & \multicolumn{3}{|l|}{ No interest } & & \\
\hline$\square$ & \multicolumn{3}{|c|}{ Too hard to find resources } & & \\
\hline$\square$ & \multicolumn{3}{|c|}{ Other: } & & \\
\hline \multicolumn{4}{|c|}{ Do you include Latino/Latina voices in your social studies lessons? } & ves & no \\
\hline \multicolumn{6}{|l|}{ If yes, how often: } \\
\hline $\begin{array}{c}\text { Multiple times } \\
\text { per week } \\
\square\end{array}$ & $\begin{array}{c}\text { Weekly } \\
\square\end{array}$ & $\begin{array}{c}\text { Monthly } \\
\square\end{array}$ & $\begin{array}{c}\text { Seldom } \\
\square\end{array}$ & \multicolumn{2}{|c|}{ Rarely, if ever } \\
\hline \multicolumn{3}{|l|}{ If not, why not: } & & & \\
\hline 口 & \multicolumn{2}{|l|}{ Not required } & & & \\
\hline$\square$ & \multicolumn{2}{|l|}{ Not enough time } & & & \\
\hline$\square$ & \multicolumn{2}{|c|}{ No interest } & & & \\
\hline$\square$ & \multicolumn{2}{|c|}{ Too hard to find resources } & & & \\
\hline$\square$ & \multicolumn{2}{|c|}{ Other: } & & & \\
\hline \multicolumn{3}{|c|}{$\begin{array}{l}\text { Do you include Native- American voices in your social } \\
\text { studies lessons? }\end{array}$} & yes & \multicolumn{2}{|l|}{$\mathrm{n}$} \\
\hline
\end{tabular}




\begin{tabular}{|c|c|c|c|c|}
\hline \multicolumn{5}{|l|}{ If yes, how often: } \\
\hline $\begin{array}{l}\text { Multiple times } \\
\text { per week } \\
\square\end{array}$ & $\begin{array}{c}\text { Weekly } \\
\square\end{array}$ & $\begin{array}{c}\text { Monthly } \\
\square\end{array}$ & $\begin{array}{c}\text { Seldom } \\
\square\end{array}$ & Rarely, if ever \\
\hline \multicolumn{5}{|l|}{ If not, why not: } \\
\hline$\square$ & \multicolumn{3}{|l|}{ Not required } & \\
\hline$\square$ & \multicolumn{3}{|l|}{ Not enough time } & \\
\hline$\square$ & \multicolumn{3}{|c|}{ No interest } & \\
\hline$\square$ & \multicolumn{3}{|c|}{ Too hard to find resources } & \\
\hline$\square$ & \multicolumn{3}{|c|}{ Other: } & \\
\hline \multicolumn{3}{|c|}{$\begin{array}{l}\text { Do you include Lesbian, Gay, Bi-sexual, Transgender, } \\
\text { Queer (LGBTQ) voices in your social studies lessons? }\end{array}$} & yes & $\mathrm{n}$ \\
\hline \multicolumn{5}{|l|}{ If yes, how often: } \\
\hline $\begin{array}{l}\text { Multiple times } \\
\text { per week } \\
\quad \square\end{array}$ & $\begin{array}{c}\text { Weekly } \\
\square\end{array}$ & $\begin{array}{c}\text { Monthly } \\
\square\end{array}$ & Seldom & Rarely, if ever \\
\hline \multicolumn{3}{|l|}{ If not, why not: } & & \\
\hline$\square$ & \multicolumn{2}{|l|}{ Not required } & & \\
\hline$\square$ & \multicolumn{2}{|l|}{ Not enough time } & & \\
\hline$\square$ & \multicolumn{2}{|c|}{ No interest } & & \\
\hline$\square$ & \multicolumn{2}{|c|}{ Too hard to find resources } & & \\
\hline$\square$ & \multicolumn{2}{|c|}{ Other: } & & \\
\hline \multicolumn{3}{|c|}{$\begin{array}{l}\text { Do you include Asian voices in your social studies } \\
\text { lessons? }\end{array}$} & yes & no \\
\hline
\end{tabular}




\begin{tabular}{|c|c|c|c|c|}
\hline \multicolumn{5}{|l|}{ If yes, how often: } \\
\hline $\begin{array}{l}\text { Multiple times } \\
\text { per week } \\
\end{array}$ & $\begin{array}{c}\text { Weekly } \\
\square\end{array}$ & $\begin{array}{c}\text { Monthly } \\
\square\end{array}$ & $\begin{array}{c}\text { Seldom } \\
\square\end{array}$ & $\begin{array}{c}\text { Rarely, if ever } \\
\square\end{array}$ \\
\hline \multicolumn{5}{|l|}{ If not, why not: } \\
\hline$\square$ & Not reauired & & & \\
\hline$\square$ & \multicolumn{2}{|l|}{ Not enough time } & & \\
\hline$\square$ & \multicolumn{2}{|c|}{ No interest } & & \\
\hline$\square$ & \multicolumn{2}{|c|}{ Too hard to find resources } & & \\
\hline$\square$ & \multicolumn{2}{|c|}{ Other: } & & \\
\hline \multicolumn{3}{|c|}{$\begin{array}{l}\text { Do you include Religious Minority voices in your social } \\
\text { studies lessons? }\end{array}$} & yes & no \\
\hline \multicolumn{5}{|l|}{ If yes, how often: } \\
\hline $\begin{array}{c}\text { Multiple times } \\
\text { per week } \\
\square\end{array}$ & $\begin{array}{c}\text { Weekly } \\
\square\end{array}$ & $\begin{array}{c}\text { Monthly } \\
\square\end{array}$ & Seldom & $\begin{array}{c}\text { Rarely, if ever } \\
\square\end{array}$ \\
\hline \multicolumn{3}{|l|}{ If not, why not: } & & \\
\hline$\square$ & \multicolumn{2}{|c|}{ Not required } & & \\
\hline$\square$ & \multicolumn{2}{|c|}{ Not enough time } & & \\
\hline$\square$ & \multicolumn{2}{|c|}{ No interest } & & \\
\hline$\square$ & \multicolumn{2}{|c|}{ Too hard to find resources } & & \\
\hline$\square$ & \multicolumn{2}{|c|}{ Other: } & & \\
\hline
\end{tabular}

\section{Part III}

Questionnaire

1. How do district/federal initiatives affect your feelings of autonomy in your content choices?

2. What units do you tend to incorporate women's perspectives? 
3. Does the textbook you use provide sufficient material to present women's voices? What book do you use?

4. What other resources do you use to supplement the text to bring in women's perspectives?

5. Does your classroom décor reflect both male and female representations (i.e. posters, timelines, bulletin boards, etc.). OR

Please list the posters/décor you have up in your classroom on a regular basis:

6. Do you incorporate more or fewer multiple perspectives in your lessons than you have in the past? Please explain why.

\section{Part IV}

Demographics

\begin{tabular}{|c|c|c|}
\hline \multirow[t]{7}{*}{1.} & \multicolumn{2}{|c|}{ How many years have you been teaching? } \\
\hline & \multicolumn{2}{|l|}{$1-3$} \\
\hline & \multicolumn{2}{|l|}{$4-8$} \\
\hline & \multicolumn{2}{|l|}{$9-12$} \\
\hline & \multicolumn{2}{|l|}{$13-20$} \\
\hline & \multicolumn{2}{|l|}{$20-30$} \\
\hline & \multicolumn{2}{|l|}{$31+\square$} \\
\hline \multirow{7}{*}{2.} & \multicolumn{2}{|c|}{ What is your highest level of schooling? } \\
\hline & Bachelor's Degree & $\square$ \\
\hline & Some graduate school & $\square$ \\
\hline & \multirow{2}{*}{ Master's degree } & \\
\hline & & $\square$ \\
\hline & $\begin{array}{l}\text { Specialist Degree } \\
\text { (Master's }+30 \text { hrs.) }\end{array}$ & $\square$ \\
\hline & Doctorate & $\square$ \\
\hline 3. & \multicolumn{2}{|c|}{ What is/are your degree(s) in? } \\
\hline \multirow[t]{3}{*}{4.} & \multicolumn{2}{|l|}{ What is your sex? } \\
\hline & \multicolumn{2}{|l|}{ Female } \\
\hline & Male & \\
\hline 5. & What is your age? & \\
\hline & 20-25 $\square$ & \\
\hline
\end{tabular}




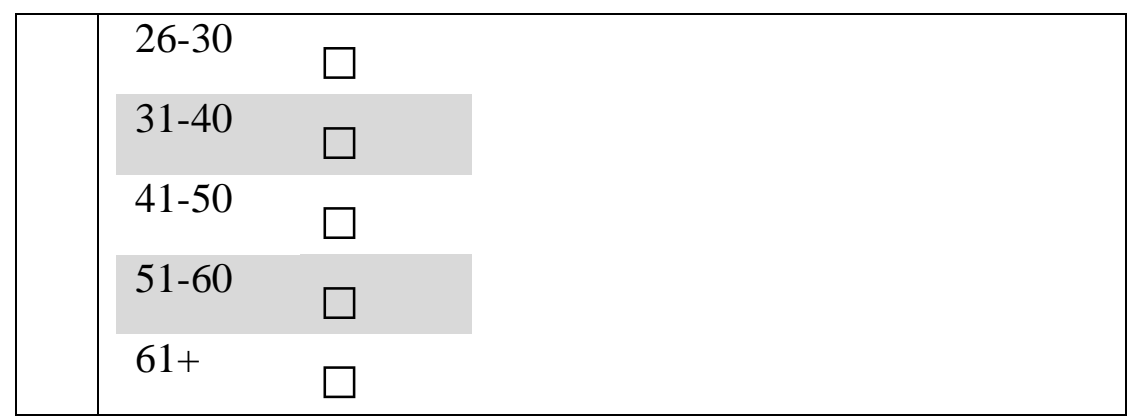

Please Place Any Additional Comments in the Box Below

If you would like to participate in a follow up interview, please list your contact information, i.e. name and email or phone number.

Thank You for Your Time! 
APPENDIX B: IRB APPROVAL 


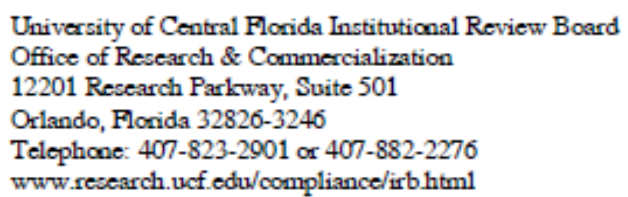

\title{
Approval of Exempt Human Research
}

\author{
From: UCF Institutional Review Board \#1 \\ FWA00000351, IRB00001138 \\ To: Cicely S. Scheiner-Fisher \\ Date: $\quad$ March 20, 2013
}

Dear Recearcher:

On $3 / 20 / 2013$, the IRB approved the following activity as human participant research that is exempt from regulation:

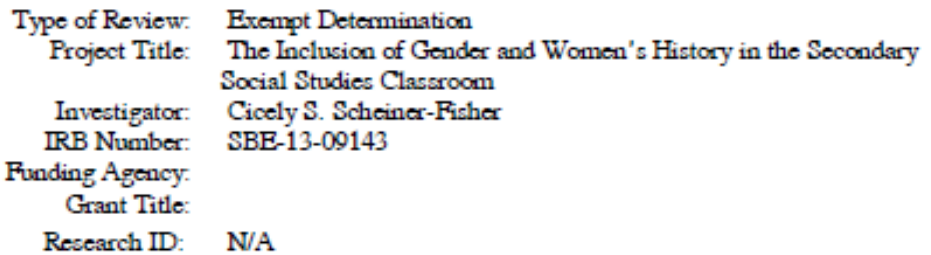

This determination applies only to the activities described in the IRB submission and does not apply should any changes be made. If changes are made and there are questions about whether these changes affect the exempt status of the human research, please contact the IRB. When vou have eompleted vour research. please submit a Study Clocure request in iRIS so that IRB records will be accurate.

In the conduct of this research, you are responsible to follow the requirements of the Investigator Manual.

On behalf of Sophia Dziegielewski, Ph.D., L.C.W., UCF IRB Chair, this letter is signed by:

Sipnature applied by Patria Davis co 03/20/2013 03:48:26 FM EST

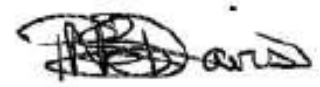

IRB Coordinator

Page 1 of 1 
APPENDIX C: DEBRIEF STATEMENT 


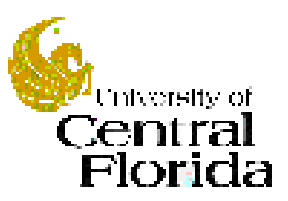

\author{
Debriefing Statement \\ For the study entitled: \\ The Inclusion of Women's History in the Secondary Social Studies Classroom
}

Dear Participant;

During this study, you were asked to complete a survey, interview and classroom observation research to examine which multiple perspectives are included in social studies classes on a regular basis.

You were told that the title of the study was The Inclusion of Multiple Perspectives in the Secondary Social Studies Classroom and the purpose of the study was to examine which multiple perspectives are included in social studies classes on a regular basis. The actual purpose of the study was to examine the motivation for why some secondary social studies teachers exceed expectations of the required curriculum to incorporate women's voices into the traditional history framework; thus the actual title of the study is The Inclusion of Women's History in the Secondary Social Studies Classroom.

We did not tell you everything about the purpose of the study because it is believed that knowing the true nature of the study would influence your responses to the survey questions as well the interview process

You are reminded that your original consent document included the following information:

Withdrawing from the study: You may decide not to continue in the research study at any time without it being held against you. If you do not want to be involved in this research study, do not proceed in the survey, or let the researcher know if you have already done so. If you consent now, and later decide you would like to leave the study, please contact the researchers. Contact information is provided below.

If you have any concerns about your participation or the data you provided in light of this disclosure, please discuss this with us. We will be happy to provide any information we can to help answer questions you have about this study.

Now that you know the true nature of the study, you have the option of having your data removed from the study. Please contact the PI if you do not want your data to be used in this research and it will be withdrawn.

Study contact for questions about the study or to report a problem: If you have questions, concerns, or complaints or think the research has hurt you, please contact Cicely Scheiner-Fisher, Ph.D. candidate by email, cicely.scheiner-fisher@ucf.edu, (407) 823- 5108; or Dr. William Russell, Russell@ucf.edu, phone (407) $823-4345$.

IRB contact about your rights in the study or to report a complaint: Research at the University of Central Florida involving human participants is carried out under the oversight of the Institutional Review Board (UCF IRB). This research has been reviewed and approved by the IRB. For information about the rights of people who take part in research, please contact. Institutional Review Board, University of Central Florida, Office of Research \& Commercialization, 12201 Research Parkway, Suite 501, Orlando, FL 32826-3246 or by telephone at (407) 823-2901.

Please again accept our appreciation for your participation in this study. 


\section{REFERENCES}

Berkin, C., Crocco, M. S., \& Winslow, B. (2009). Clio in the classroom: A guide for teaching U.S. women's history. New York: Oxford University Press.

Breland, H., Danos, D. O., Kahn, H. D., Kubota, M. Y. , \& Bonner, M. W. (1994). Performance versus objective testing and gender: An exploratory study of an Advanced Placement history examination. Journal of Educational Measurement, 31(4), 275-293.

Buck, G., Kostin, I, \& Morgan, R. (2002). Examining the realtionship of content to gender-based performance differences in Advanced Placement exams. New York, NY: The College Board.

Buschman, J. K., \& Lenart, S. . (1996). "I am not a feminist, but...": College women, feminism, and negative experiences. Political Psychology, 17(1), 59-75.

Clark, R., Ayton, K., Frechette, N., \& Keller, P. J. (2005). Women of the world, re-write! Women in American world history high school textbooks from the 1960's, 1980's and 1990's. Social Education, 69(1).

Copp, M., \& Kleinman, S. (2008). Practicing what we teach: Feminist strategies for teaching about sexism. Feminist Teacher, 18(2), 101-124.

Creswell, J. W. (2007). Qualitative inquiry \& research design: Choosing among five approaches. Thousand Oaks, CA: Sage Publications, Inc.

Crocco, M. S. (1997). Making time for women's history...when your survey course is already filled to overflowing. Social Education, 6(1), 32-37.

Crocco, M. S. (1999). Introduction. In M. S. Crocco \& O. L. Davis (Eds.), "Bending the future to their will": Civic women, social education, and democracy (pp. 1-16). Oxford, UK: Rowan \& Littlefield. 
Crocco, M. S. (2001). The missing discourse about gender and sexuality in the social studies. Theory into Practice, 40(1), 65-71.

Crocco, M. S. (2008). Gender and sexuality in the social studies. In L. S. Levsktik \& C. A. Tyson (Eds.), Handbook of Research in Social Studies Education. New York: Routledge.

Cruz, B. C., \& Groendal-Cobb, J. L. (1998). Incorporating women's voices into the middle and senior high school history curriculum. Social Studies, 89(6), 271.

Dewey, J. (1916). Democracy and education. New York: The Macmillan Company.

Evans, R. W. (2004). The social studies wars: What should we teach the children? New York, NY: Teachers College Press.

Fisher, B. M. (2001). No angel in the classroom: Teaching through feminst discourse. Landham, MD: Rowman \& Littlefield.

Francis, R. W. . (1999). The Equal Rights Amendment: Unfinished business for the constitution. Retrieved May 27, 2013, from http://www.equalrightsamendment.org/

Glesne, C. (2011). Becoming qualitative researchers: An introduction. Boston, MA: Pearson. Goldberg, M. L. (2009). Redesigning the U.S. women's history survey course using feminist pedagogy, educational research, and new technologies. In C. Berkin, M. S. Crocco \& B. Winslow (Eds.), Clio in the classroom: A guide for teaching U.S. women's history. New York: Oxford Univeristy Press.

Gollnick, D., Sadker, M., \& Sadker, D. (1982). Beyond the Dick and Jane syndrome: Confronting sex bias in instructional materials. In M. Sadker \& D. Sadker (Eds.), Sex equity handbookfor schools. New York: Longman.

Hahn, C. L. (1996). Gender and political learning. Theory \& Research in Social Education, $24(1), 8-35$. 
Hahn, C. L., Bernard-Powers, J., Crocco, M. S., \& Woyshner, Christine. (2007). Gender equity and social studies. In S. Klein (Ed.), Handbook of research on gender equity. Mahwah: Lawrence Erlbaum Associates.

The Heritage Foundation. (2013). About heritage. Retrieved from http://www.heritage.org/about.

Holt, E. R. (1990). "Remember the ladies" --Women in the curriculum. ERIC Digest.

Kessler-Harris, A. (2007). Do we still need women's history? The Chronicle of Higher Education, 54(15), B6-7.

Kivinen, O., \& Ristela, P. (2003). From constructivism to a pragmatist conception of learning. Oxford Review of Education, 29(3), 363-375.

Klein, S., Ortman, B., \& Friedman, B. . (2002). What is the field of gender equity in education? In J. Koch \& B. Irby (Eds.), Defining and redefining gender equity in education. Greenwich, CT: Information Age Publishers.

Lather, P. (1991). Getting Smart: Feminist research and pedagogy with/in the postmodern. New York, NY: Routledge.

Lerner, G. (1981). The Majority finds its past. New York: Oxford University Press.

Lerner, G. (1993). The creation of feminist consciousness: From the middle ages to eighteenseventy. New York, NY: Oxford University Press.

Minnich, E. K. (1990). Transforming knowledge. Philadelphia: Temple University Press.

National Council for the Social Studies. (2010). National curriculum standards for the social studies: A framework for teahing, learning and assessment. Washington, DC: Author.

Noddings, N. (1992). Social studies and feminism. Theory \& Research in Social Education, 20(3), 230-241. 
Noddings, N. (2002). Educating moral people: A Caring alternative to character education. New York, NY: Teachers College Press.

Patton, M. Q. (2002). Qualitative evaluation and research methods (3rd ed.). Thousand Oaks, CA: Sage Publications.

Purvis, J. (2004). Women's history today. History Today, 54(11), 40-42.

Rogers, J. B. (1990). Into, through and beyond...a history class. History and Social Science Teacher, 25(2), 82-87.

Sadker, D., Sadker, M., \& Zittleman, K. R. (2009). Still Failing at Fairness. New York: Scribner.

Santora, E. D. (2011). 21st Century democratic social and citizenship education. In W. B. Russell III (Ed.), Contemporary social studies: An essential reader. Charlotte, NC: Information Age Publishing, Inc.

Schafer, C. M. (2007). A Deliberate reconstruction and reconfiguring of women in history: One teacher's attempt at transforming a U.S. History Curriulum. (Ph.D.), Georgia State University, Atlanta. (3272887)

Scheiner-Fisher, C., \& Russell, W. B. (2012). Using historical films to promote gender equity in the history curriculum. The Social Studies 103(05).

Schmeichel, M. (2011). Feminism, neoliberalism and social studies. Theory \& Research in Social Education, 39(1), 26.

Schreiner, B. (2013, April 22, 2013). Equal rights issue raised once again, Florida Today.

Scott, J. W. (1997). Women's history and the national history standards. Journal of Women's History, 9(3), 172-177. 
Seidman, I. (2006). Interviewing as qualitative research: A guide for researchers in education and the social sciences. New York: Teacher's College Press.

Seigfried, C. H. (1996). Pragmatism and feminism: Reweaving the social fabric. Chicago: University of Chicago Press.

Simmons, R. (2003). Odd girl out: The hidden culture of aggression in girls. Boston: Houghton Mifflin Harcourt

Sullivan, A., Joshi, H., \& Leonard, D. (2010). Single-sex schooling and academic attainment at school and through the lifecourse. American Educational Research Journal, 47(1), 6-36.

Tetreault, M. K. T. (1986a). Integrating women's history: The case of united states history hight school textbooks. The History Teacher, 19(2), 211-262.

Tetreault, M. K. T. (1986b). "It's so opinioney". Journal of Education, 186(2), 78-95.

Tetreault, M. K. T. (1987). Rethinking women, gender, and the social studies. Social Education, $51,170-178$.

Trecker, J. L. (1973). Women in U. S. history high school textbooks. International Review of Education, 19(1), 133-139.

Unknown (Writer). (2007). Full metal corset: secret soldier of the civil war [DVD]: History Channel.

Villaverde, L. E. (2008). Feminist theories and education. New York: Peter Lang Publishing Inc.

Wineburg, S. (2001). Historical thinking and other unnatural acts. Philadelphia, PA: Temple University Press.

Woyshner, C. (2011). Gender and social studies. In W. B. R. III (Ed.), Contemporary social studies: An essential reader. Charlotte, NC: Information Age Publishing, Inc. 
